\title{
健康管理 I
}

$1 \mathrm{~A} 01$ 集団検診における血清ペプシノーゲンの応用

○松尾弘文、福山靖子、福井実、杉村攸、小西行夫

( 旭川厚生病院)

細川 正浩

はじめに、最近胃癌のスクリーニング法と

( 同：臨床検査科 )

して、P G 測定が注目されているが、今度 $\mathrm{H}$ 町における健診受診者全員について血清 $P G$ を測定する事ができたので性・年路による血 清 $\mathrm{P} \mathrm{G}$ 各フラクションの変動、胃間接写真ス クリーニングによる異常群との関係について 検討をする事ができたので報告する。

対象及び方法：健診受診は男性 259 名、女 性 399 名、計 658 名である。表 I 、血清 P G の測定はSRL 社に依頼し、血清PGI、PGIIか らPGI /PGII比を算出した。受診者全員は胃 間接 $\mathrm{X}$ 線検査を実施しているが、X線写真よ り要精密検査となり内視鏡検査による精査を 5けた例の胃病変と血清 $\mathrm{P}$ G の関係と、X線 写真では異常所見はなくとも、I / II比が 1.0 未満とその値が極端に低い例に就いては、X 線写真では異常所見がなくても内視鏡検査を 実施し胃病変との関係を検討した。又当院臨 床にて発見された胃癌手術例20例について、 術前PGI、PGII及びその比を測定し、P G と 胃癌との関係についても合わせて検討した。

結果と考察：一般に健常群においては年齿 による変化が見られ、PGIは50才汽横ばいで あり60才代以後低值を、PGIIは加齢と共に漸 増傾向を示し、I／II比は加㱓と共に段階的に 低値を示すと云われている。私達の調査では 平均値では、30才代女性を除くと年秢が高く なるにつれ漸減傾向を示した。図 I、PGII も 平均值において男性では横ばい傾向にあり、 女性では30才代を除いて年齢が高くなるにつ れ低值傾向を示した。図2、I/什において は男女共加秢と共に低値を示している。図 3 今回 658 名の内要精検者は77名 $(11.7 \%)$ であ り、その内受診した者は 74 名 $(96 \%)$ で、内 早期胃癌 2 名発見され発見率は $0.3 \%$ あっった。 表 2 は健常群と疾患群における各成分值 である。その平均値を比較すると、PGIIにつ いて慢性胃炎群では高い傾向であった。胃ポ

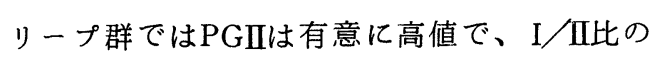
平均値は低値であった。その他の疾患群との 間に有意差は認められなかった。

P G は胃液中の蛋白分解䣼素であるペプシン の不活性型前駆体で主細胞で産生される。 1970年 Samloff らよってPG I、PGII分類 する事が提唱され、PGIは胃底腺領域より分 泌され、PGIIは胃底腺、幽門腺、12指腸腺領 域より分泌されその一部が血中に入るとされ ている。現在ではRIA法を用いる事によりそ の測定が可能となった。三木らはPGI、PGII、 I/五比の組合せ等により低值群における胃癌、 及び高值群における消化性潰瘍の血清学的ス クリーニングの可能性を報告している。しか しての度の健診で発見された 2 例の早期胃癌 例では、P G は、1 例はスクリーニング判定 基準に入っていたが他の 1 例はその範囲に入 っていなかった。

表 3

表 4 は今回の健診受診者のうち健常群と当院 臨床において見出された胃癌群をマッチング して平均值を比較したものであるが、進行胃 癌側では、PGI、I/I比が有意に低值であっ たが、早期胃癌側では、いずれも差は認めら れなかった。P G は萎縮胃粘膜を背景として 
発生する分化型胃癌をスクリーニングする事 を期待されているが、今度の検討では健診に 於て最重要である早期癌ではあまり有意な変 化は認められず、又 I/II比とPGI值の組み合 わせで、スクリーニング判定基準、PG I $<70$ $\mathrm{ng} / \mathrm{m \ell} 、 \mathrm{I} / \mathrm{II}$ 比 $<3$ とするとその範囲では要 精検率が、40.3\%にもなるし、I/II比が特に
低い群で、しかもX線上異常がない例でも今 度の検討では悪性所見は発見する事は出来ず P G の健診への応用には今後共検討を加えね ばならないと考えている。

(表 1 ) 受彭者の年代性別

\begin{tabular}{|c|c|c|c|c|c|c|}
\hline & $30 \sim 39$ & $40 \sim 49$ & $50 \sim 59$ & $60 \sim 69$ & $70 \sim 79$ 才 & 計 \\
\hline 男性 & 20 & 52 & 66 & 83 & 38 & 259 \\
\hline 女性 & 41 & 89 & 124 & 110 & 35 & 399 \\
\hline
\end{tabular}

（因１） P G 㑮の作命别男女别分布

$P$ G I

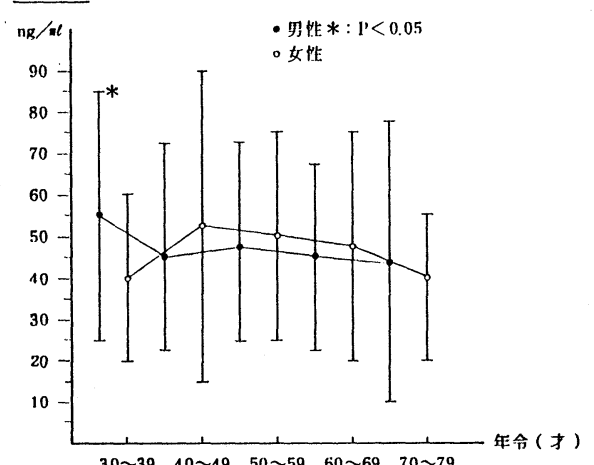

(因2)

P G II

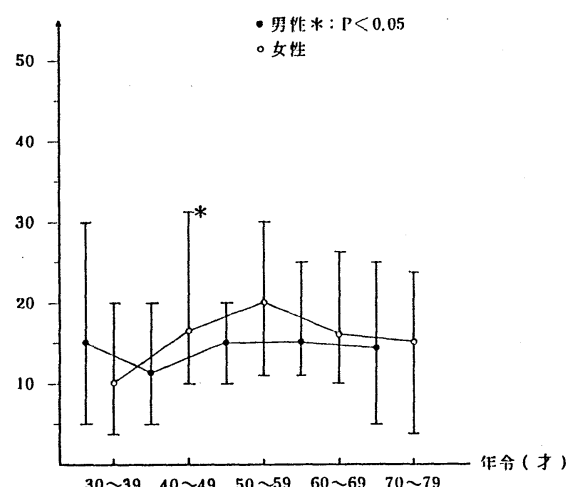

(因3)

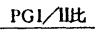

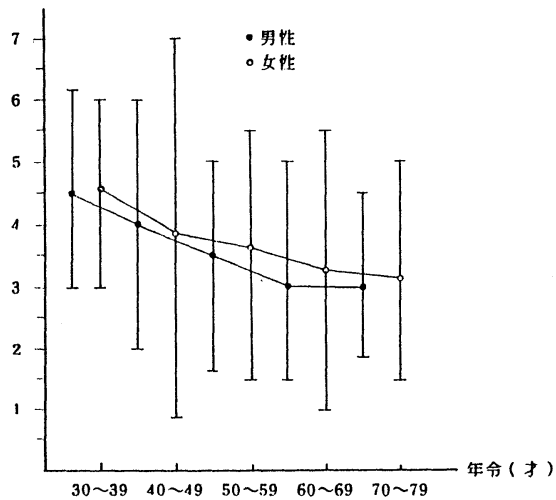

（表 2 ) 健常群及び各疾患群の血清 P G 各成分估

$* *: \mathrm{P}<0.01$

$*: \mathrm{P}<0.05$

\begin{tabular}{|c|c|c|c|c|c|}
\hline 診 断 名 & 例 数 & 平均年命 & P G I & P G II & I $/ \mathrm{II}$ 比 \\
\hline 健 常 群 & 598 & $55.0 \pm 11.2$ & $48.1 \pm 27.9$ & $15.9 \pm 10.2$ & $3.7 \pm 2.1$ \\
\hline 慢性胃炎 & 38 & $60.0 \pm 11.5$ & $49.0 \pm 34.1$ & $21.1 \pm 12.8^{* *}$ & $2.6 \pm 16.4$ \\
\hline 胃 潰 䢀 & 11 & $62.2 \pm 10.5$ & $53.0 \pm 48.6$ & $17.0 \pm 11.0$ & 2. $9 \pm 1.2$ \\
\hline 胃ボリープ & 6 & $55.7 \pm 10.7$ & $41.4 \pm 26.7$ & $24.7 \pm 10.9^{*}$ & $1.7 \pm 0.9^{*}$ \\
\hline 癌 & 2 & $56.5 \pm 15.5$ & $40.9 \pm 13.8$ & $12.2 \pm 3.0$ & $3.3 \pm 0.3$ \\
\hline 十二指腸謴瑝 & 3 & $65.7 \pm 10.7$ & $77.4 \pm 18.8$ & $18.7 \pm 2.1$ & $4.1 \pm 0.6$ \\
\hline
\end{tabular}

(表 3 ) 疾患群

対照群

$* * * \mathrm{P}<0.001$

\begin{tabular}{|l|l|l|l|l|l|l|l|l|l|l|l|l|}
\hline No & 性 & 年令 & 疾患 & PG I & PGII & I/訨 & No & 性 & 年令 & PG I & PGII & I/II比 \\
\hline
\end{tabular}

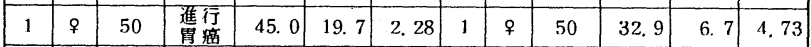

\begin{tabular}{|l|l|l|l|l|l|l|l|l|l|l|l|l|}
\hline 2 & 9 & 57 & $\prime \prime$ & 24.4 & 11.0 & 2.22 & 2 & 9 & 57 & 53.4 & 10.2 & 5.24 \\
\hline
\end{tabular}

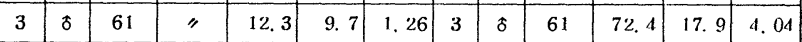

\begin{tabular}{|l|l|l|l|r|r|r|r|r|r|r|r|r|}
\hline 4 & f & 62 & $\prime \prime$ & 15.4 & 13.1 & 1.18 & 4 & $\delta$ & 62 & 55.5 & 15.7 & 3.54 \\
\hline 5 & 9 & 66 & $"$ & 9.5 & 8.3 & 1.14 & 5 & 9 & 66 & 35.3 & 9.5 & 3.73 \\
\hline
\end{tabular}

\begin{tabular}{|l|l|l|l|r|r|r|r|r|r|r|r|r|}
\hline 5 & 9 & 66 & $\prime \prime$ & 9.5 & 8.3 & 1.14 & 5 & $q$ & 66 & 35.3 & 9.5 & 3.73 \\
\hline
\end{tabular}

\begin{tabular}{|l|l|l|l|l|l|l|l|l|l|l|l|l|l|}
\hline 6 & $\delta$ & 69 & $\prime \prime$ & 14.2 & 5.3 & 2.68 & 6 & $\delta$ & 69 & 60.4 & 19.6 & 3.08 \\
\hline 7 & 8 & 69 & $" 1$ & 14.2 & 14.1 & 1.01 & 7 & 8 & 69 & 26.6 & 17.1 & 1.56 \\
\hline
\end{tabular}

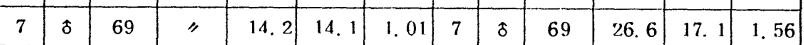

\begin{tabular}{|l|l|l|l|l|l|l|l|l|l|l|l|l|}
\hline 8 & 9 & 73 & $" 16.0$ & 13.0 & 1.23 & 8 & 9 & 73 & 83.7 & 20.0 & 4.19 \\
\hline 9 & 9 & 77 & $" 16$ & 19.7 & 5.6 & 3.51 & 9 & 9 & 77 & 51.0 & 7.9 & 6.46 \\
\hline
\end{tabular}

\begin{tabular}{|l|l|l|l|l|l|l|l|l|l|l|l|l|}
\hline 9 & + & 77 & $\prime \prime$ & 19.7 & 5.6 & 3.51 & 9 & 9 & 77 & 51.0 & 7.9 & 6.46 \\
\hline 10 & 6 & 78 & $"$ & 6.6 & 7.9 & 0.83 & 0 & 8 & 78 & 108 & 26.2 & 4.12 \\
\hline
\end{tabular}

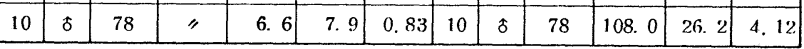

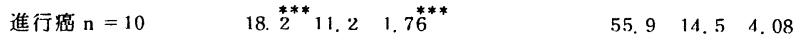

$\pm 9.9 \pm 4.2 \pm 0.80 \quad \pm 23.4 \pm 6.0 \pm 1.18$

[表 4) 疾患群

対照群

\begin{tabular}{|c|c|c|c|c|c|c|c|c|c|c|c|c|}
\hline No & 性 & 年令 & 疾患 & PG I & PGII & 1/11此 & No & 性 & 年命 & PGI & PGII & $1 / 1 \mathrm{II}$ \\
\hline 1 & $\delta$ & 49 & 早期婹 & 23. 0 & 16. 0 & 2.00 & 1 & $\delta$ & 49 & 35.7 & 8. 6 & 4.18 \\
\hline 2 & $q$ & 54 & " & 43. 8 & 30.3 & 1. 45 & 2 & $q$ & 54 & 78. 9 & 21.3 & 3. 70 \\
\hline 3 & i & 57 & " & 29.8 & 15.0 & 1.99 & 3 & $q$ & 57 & 61.4 & 25.3 & 2. 43 \\
\hline 4 & $\delta$ & 62 & " & 29.8 & 9. 5 & 3. 14 & 4 & $\delta$ & 62 & 48.6 & 20.3 & 2. 39 \\
\hline 5 & $\hat{\delta}$ & 63 & " & 37. 0 & 15.0 & 2. 47 & 5 & $\delta$ & 63 & 87. 5 & 30.0 & 2. 92 \\
\hline 6 & $\delta$ & 66 & " & 28.4 & 17.4 & 1. 63 & 6 & $\delta$ & 66 & 25.2 & 4.3 & 5.82 \\
\hline 7 & $\delta$ & 67 & " & 34.2 & 19.4 & 1. 76 & 7 & $\delta$ & 67 & 75. 2 & 31.4 & 2.39 \\
\hline 8 & $\delta$ & 67 & " & 35.9 & 18.0 & 1. 99 & 8 & $\delta$ & 67 & 16. 1 & 11.7 & 1. 58 \\
\hline 9 & q & 73 & " & 61.6 & 19.1 & 3. 18 & 9 & $q$ & 73 & 13.3 & 12.8 & 1. 04 \\
\hline 10 & $\delta$ & 73 & " & 20.5 & 10.1 & 2. 03 & 10 & $\delta$ & 73 & 28. 9 & 18.6 & 1.55 \\
\hline & & & & $\begin{array}{r}34.4 \\
\pm 11.1\end{array}$ & & $\begin{array}{l}\text { 2. } 16 \\
0.56\end{array}$ & & & & $\begin{array}{r}47.1 \\
\pm 259\end{array}$ & $\begin{array}{r}18.4 \\
\pm 8.6\end{array}$ & \\
\hline
\end{tabular}




\section{A02}

集団健康スクリーニングからみた食生活の改善と 肥満について

○西垣良夫、宮沢昭一、松島松翠

（長野県厚生連健康管理センター）

\section{【はじめに】}

農村地域の食生活の都市化、洋風化がます ますすすむなかで、肥満や肥満に関連した健 康障害が農村でも増加の傾向であることが知 られている。それゆえ健康診断後の健康教育 の場面でも成人病の予後軍である肥満の改善 対策は重要なテーマの一つとなっている。近 年、長野県厚生連の集団健康スクリーニング の結果報告書には問診に基いて食品摂取状況 の過不足を示すようにしている。この栄養バ ランスの全般的な状況の変化と肥満との関連 について調查検討し、日常の食生活改善の手 だての一つとして活用したい。

\section{【対象と方法】}

1990年 4 月 1 日より1991年 1 月31日までの 長野県下集団健康スクリーニング受診者のう ち、年令が $40 \sim 69$ 才で 2 年前にも同じ健康ス クリーニングを受診している者29,846人（男 11,571 人、女 18,275 人) について性・年令階 級別（40代、50代、60代）に分け、食生活の 改善状況により次のように分類した。A群： 2 年前に比較し改善している群、B群 : 2 年 前に比較し悪化している群、C 群 : 2 年前と 同椂に引き続き不良である群、 $\mathrm{D}$ 群 : 2 年前 と同様に引き続き良好である群の 4 群である （表一1）。各群ごとに自覚症状、検査、総 合判定などについて比較検討したが、今回は 肥満を中心に報告する。なお食生活の改善の 有無については表－2の判定基準に従って、 各食品群の摂取量が不足または過多の項目が 14 項目のうち 3 項目以上だったものが 2 年後
には2 項目以下に減少した場合を「改善」、 2 項目以下だったものが 3 項目以上に増加し た場合を「悪化」、常に 3 項目以上の場合を 「同様に不良」、常に 2 項目以下の場合「同 様に良好」と判定した。

\section{【結果と考察】}

食生活の全般的なバランスの変化と肥満の 状況とについてみると、肥満率20\%以上の割 合は、男の40代はC 群 : B 群 : A 群 : D 群= $30.3 \%: 20.2 \%: 19.1 \%: 13.3 \%$ 、50代は同样に $29.8 \%: 21.4 \%: 15.3 \%: 11.8 \%$ 、60代は同様に $21.8 \%: 13.3 \%: 8.4 \%: 5.3 \%$ である。女の 40 代 はC群：B群：A群：D群=26.8\%:20.6\%：

9.3\%：4.6\%、50代では同様に $31.7 \% ： 19.9 \%$ : 10.9\%：4.9\%、60代では同样に $28.6 \%: 15.8 \%$ : $10.6 \%: 4.4 \%$ である（図一 1 ）。すなわち全て $\mathrm{C}$ 群 $>\mathrm{B}$ 群 $>\mathrm{A}$ 群 $>\mathrm{D}$ 群の順で肥満者率が低 下する。また BMI（体重/身長 ${ }^{2}$ ）でみて もほぼ同様の傾向である（図-2）。

食生活のバランスがいつも良好である群が 最も肥満者率が低く、反対にバランスがいつ も不良である群が最も肥満者率が高いことは 予期されたことであるが、食生活の態度が変 容した群が前二者の中間的な位置にあり、さ らに改善群の方が悪化群より肥満者率が低い ことは興味深いことである。以前は食生活の バランスが悪かった群であっても、日常の食 生活の注意によって肥満者率が減ることがわ かる。また肥満と関連のある高血圧（男女）、 女の総合判定についても肥満ほどきわだって はいないが同様の傾向である。 
食生活の全般的な改善効果がどの食品群に

とくによく現われているかについてみると、 過多であったものが適量に大きく変化したも のは男では油脂、女では油脂と糖分であり、
かな栄養バランスの記載は、マスとしてみれ ば、肥満の一定の改善効果も期待しうること がうかがわれる。
不足していたもの

が適量に大きく変

化したものは男で は緑黄野菜、豆腐

・納豆、肉類・八 ムであり、女で緑 黄野菜、豆腐・納 豆、肉類・八厶、 牛乳・チーズであ る。

今日の農村地域 における健康教育 の現場では様々な 工夫をこらした肥 満対策を行ってい るが、実際には目 にみえた効果がな かなかえられない ことが多い。肥満 者の長年の食習慣 を変容させること は大きな努力が必 要である。私ども が近年意識的にと りくんでいる気づ き型の学習会（健 診後の報告会など で受診者自身が自 分の健診結果の経 年的変化をグラフ に記入する）や結 果報告書への大ま
表一1刘华者の分類

\begin{tabular}{|c|c|c|c|c|c|c|c|c|}
\hline 分頪群 & $40-49$ & $50-59$ & $60-69$ & 男合暗 & $40-49$ & $50-59$ & $60-69$ & 女合㹬 \\
\hline $\begin{array}{l}\mathrm{A} \\
(\%)\end{array}$ & $\begin{array}{r}659 \\
(17.5) \\
\end{array}$ & $\begin{array}{r}620 \\
(16.6) \\
\end{array}$ & $\begin{array}{r}808 \\
(19.8) \\
\end{array}$ & $\begin{array}{l}2,087 \\
(18.0) \\
\end{array}$ & $\begin{array}{r}903 \\
(17.8) \\
\end{array}$ & $\begin{array}{r}1,224 \\
(19.0) \\
\end{array}$ & $\begin{array}{r}1,301 \\
(19.2) \\
\end{array}$ & $\begin{array}{r}3,428 \\
(18.8)\end{array}$ \\
\hline B & $\begin{array}{r}450 \\
(12.0) \\
\end{array}$ & $\begin{array}{r}462 \\
(12.4) \\
\end{array}$ & $\begin{array}{r}518 \\
(12.7) \\
\end{array}$ & $\begin{array}{r}1,430 \\
(12.4) \\
\end{array}$ & $\begin{array}{r}650 \\
(12.8) \\
\end{array}$ & $\begin{array}{r}914 \\
(14.2) \\
\end{array}$ & $\begin{array}{r}929 \\
(13.7) \\
\end{array}$ & \\
\hline $\begin{array}{l}\mathrm{C} \\
(\%)\end{array}$ & $\begin{array}{r}1,997 \\
(53.1) \\
\end{array}$ & $\begin{array}{r}2,035 \\
(54.4) \\
\end{array}$ & $\begin{array}{r}1,918 \\
(47.1) \\
\end{array}$ & $\begin{array}{r}5,950 \\
(51.4) \\
\end{array}$ & $\begin{array}{r}1,456 \\
(28.7) \\
\end{array}$ & $\begin{array}{r}2,108 \\
(32.8) \\
\end{array}$ & $\begin{array}{r}2,416 \\
(35.7) \\
\end{array}$ & $\begin{array}{r}5.980 \\
(32.7) \\
\end{array}$ \\
\hline D & $\begin{array}{r}653 \\
(17.4) \\
\end{array}$ & $\begin{array}{r}621 \\
(16.6) \\
\end{array}$ & $\begin{array}{r}830 \\
(20.4) \\
\end{array}$ & $\begin{array}{r}2,104 \\
(18.2) \\
\end{array}$ & $\begin{array}{r}2,067 \\
(40.7) \\
\end{array}$ & $\begin{array}{r}2,188 \\
(34.0) \\
\end{array}$ & $\begin{array}{l}2,119 \\
(31.3)\end{array}$ & $\begin{array}{r}6,374 \\
(34.9)\end{array}$ \\
\hline (\%) & $\begin{array}{c}3,759 \\
(100.0)\end{array}$ & $\begin{array}{r}3,738 \\
(100.0)\end{array}$ & $\begin{array}{c}4,074 \\
(100.0)\end{array}$ & $\begin{array}{l}11,571 \\
(100.0)\end{array}$ & $\begin{array}{r}5,076 \\
(100.0)\end{array}$ & $\begin{array}{r}6,434 \\
(100.0)\end{array}$ & $\begin{array}{r}6,765 \\
(100.0)\end{array}$ & $\begin{array}{c}18,275 \\
(100.0)\end{array}$ \\
\hline
\end{tabular}

\section{表一2食事罟取量判定の基染(一部)}

\begin{tabular}{|c|c|c|c|c|c|c|c|c|c|c|}
\hline \multirow[b]{2}{*}{ 牛䋘や肉・魚なとのとり方は } & \multicolumn{5}{|c|}{ 正常の人 } & \multicolumn{5}{|c|}{ 肥満・楉疗病などの人 } \\
\hline & $\begin{array}{c}1 \\
\text { ほとんと } \\
\text { とらない }\end{array}$ & $\begin{array}{c}\text { 口 } \\
1 \text { 週湖 } \\
1 \sim 2 \text { 回 }\end{array}$ & $\begin{array}{c}\text { 八 } \\
1 \text { 週朋に } \\
3 \sim 5 \text { 回 }\end{array}$ & $\begin{array}{c}= \\
1 \text { 過胆k } \\
6 \sim 8 \text { 回 }\end{array}$ & $\begin{array}{c}\text { 木 } \\
\text { もれ以上 }\end{array}$ & $\begin{array}{c}1 \\
\text { ほとんと } \\
\text { とらない }\end{array}$ & $\begin{array}{c}\text { 口 } \\
1 \text { 週间に } \\
1 \sim 2 \text { 回 }\end{array}$ & $\begin{array}{c}\text { 八 } \\
1 \text { 週间に } \\
3 \sim 5 \text { 回 }\end{array}$ & $\begin{array}{c}= \\
1 \text { 週成k } \\
6 \sim 8 \text { 回 }\end{array}$ & $\begin{array}{c}\text { 木 } \\
\text { 七れ以上 }\end{array}$ \\
\hline 牛乿・乳製品(ヨーグルト、チースも) & 不 & 不 & $p$ & 正 & 正 & 不 & 不 & $p$ & 正 & 多 \\
\hline 卵-畉料理 & 不 & 不 & p & 正 & 正 & 不 & $\frac{1}{1}$ & $p$ & 正 & 多 \\
\hline 魚介類(イカ,貝ささしみちくくわも) & 不 & 不 & $p$ & 正 & 正 & 不 & 不 & $p$ & 正 & 多 \\
\hline 肉頪(ハム、ウインナーソーセージも) & 不 & 不 & $p$ & 正 & 多 & 不 & 不 & $p$ & 正 & 多 \\
\hline 大豆類(豆ふ，納豆，谏豆ふなど) & 不 & 不 & p & 正 & 正 & 不 & 不 & $\frac{1}{p}$ & $\frac{\pi}{\underline{x}}$ & 正 \\
\hline
\end{tabular}

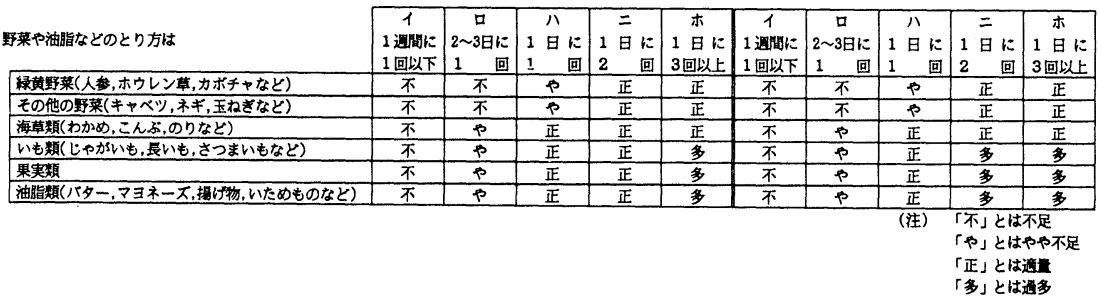

四 1 食生活的塞状況飞

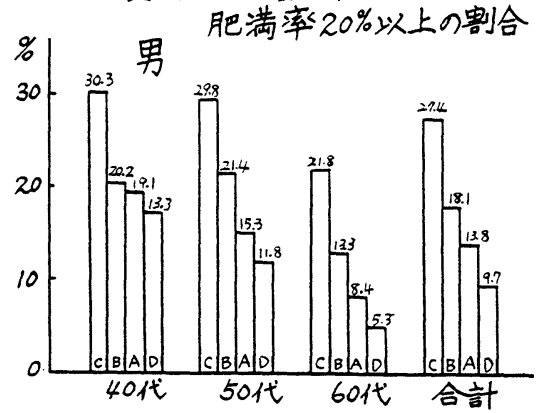

図2 食生活の改善状況と
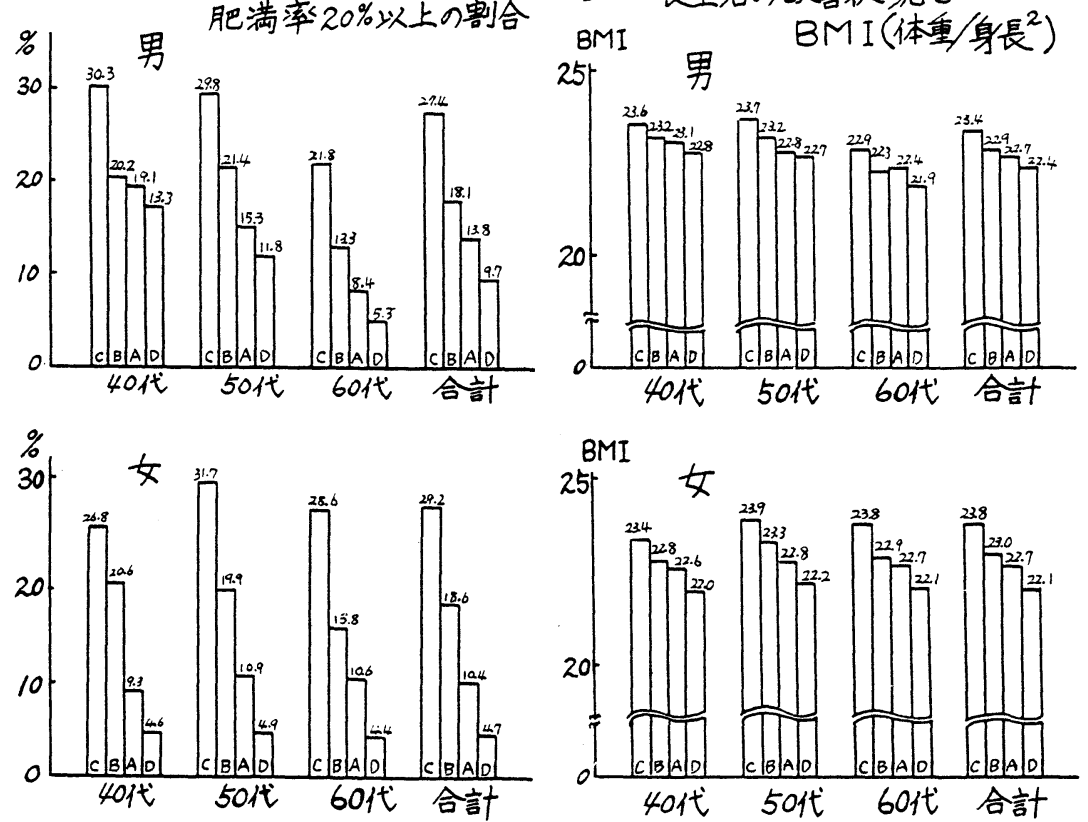
○原田 孝志、能見 晃 ( $\mathrm{J} \mathrm{A}$ 兵庫厚生連)

布施野 日出生（社会保険神戸中央病院）

\section{1. はじめに}

老人保健法保健事業第 3 次計画で、平成 4 年度から $\gamma$ -GTP.TG.HDL-CHO.CREの4項目が追加された。

これに伴い、本会の行う健診の血清脂質検査 (TG. HDLCHO)の基準值について検討したので報告する。

\section{2. 対象および方法}

(1) $\mathrm{TG}$

平成 $2 \cdot 3$ 年度の健診受診者から無作為に抽出した 14,163 人(男 5,855 人 女 8,308 人)について、性別、年代 別、食後経過時間毎に、平均值、標準偏差を求め度数分 布図を作成した。

なお、異常值の除外は平均值士2 S Dによる連続切断 法を行った。

(2) $\mathrm{HDL}-\mathrm{CHO}$

平成 3 年度の健診受診者から無作為に抽出した6,000 人(男 1,986 人 女 4,014 人)について、性別、年代別に平 均值、標準偏差を求め度数分布図を作成した。また動脈 硬化指数についても同様の計算を行った。

なお、異常值の除外は平均値士 3 S Dによる連続切断 法を行った。

※動脈硬化指数 $=(\mathrm{TCHO}-\mathrm{HDL}-\mathrm{CHO}) / \mathrm{HDL}-\mathrm{CHO}$

(3) 検査方法

T G‥酵素法(遊離グリセロール消去法)

$\mathrm{HDL}-\mathrm{CHO} \cdots$ ヘパリン $\mathrm{Ca}^{2+} \mathrm{Ni}^{2+}$ 沈澱法

(4) 出現率 (表 2)

対象...抽出人数

3. 結 果

(1) $\mathrm{T} \mathrm{G}$

T Gは食事による影響を強く受けるため、食後経過時間 毎に平均値を求めた。（図 1 ）
その結果、食後 5 時間までは高値を示し、以後 8 時間 まで減少傾向を示した。しかし、食後 9 時間〜 11時間で 増加し食後12〜16時間までは安定しているが、食後17時 間以後再び減少し食後20時間以上で性差は見られなくな った。

また、性差と経年変化を見ると、男性は30～50歳代で 高く、女性は加齢とともに増加し60歳代以上で男性より 高値を示した。(図 2)

以上の結果から、基準值設定には食後経過時間、性別、 年齢を考慮する必要があると思われたが、集団健診の性 格上細かい分析は現実性にそしく食後経過時間のみを考 慮して、食後 12 時間までと食後 12 時間 1 分以上に分類し た。

$\mathrm{T}$ Gの正常範囲の上限は平均值＋2 S D とし、要注意、 要精密検査は出現毎率を考慮し設定した。

図1. T G食後経過時間毎の平均值

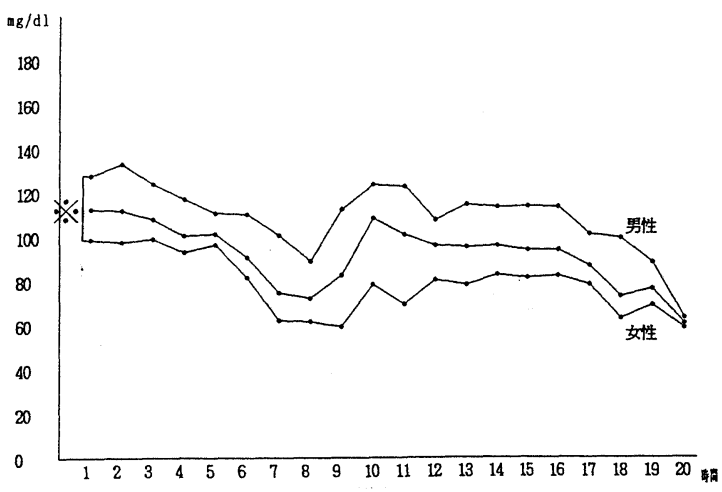
$※ \mathrm{P}<0.01$

(2) $\mathrm{HDL}-\mathrm{CHO}$

HDL-CHOは有意な性差が見られ、各年代で女性が男性に 比し高值を示した。

また女性では、TCH0が50歳代以後急速に増加するのに 
対し、HDL-CHOは40歳代 70歳代にかけて減少している。 男性では大きな経年変化は認められなかった。(図 3 )

動脈硬化指数は、TCHO と関係あるため、女性では、20 歳代から70歳代にかけてやや増加傾向を示したが、男性 では大きな変化は認められなかった。(図 4)

以上の結果から、基準值設定には性差を考慮すること としたが、HDL-CHO単独では判定が困難なこともあり、動 脈硬化指数と合わせて基準值を設定することとした。

動脈硬化指数の平均値 $+2 \mathrm{~S} \mathrm{D}$ は男女とも 5 となった が、動脈硬化指数 3 または 4 以上で冠動脈硬化の発生が 増加すると言う報告もあり動脈硬化指数の基準值は3.9 以下とした。

HDL-CHOの正常範囲の上限は、平均値＋2 S D とし、 下限は出現率や他の検査機関の基準値を参考にして設定 し、また、要注意、要精密検査は出現率を考慮し設定し た。

（表 1)

4. まとめ

基準值設定に際しては、医原病や臨床医の基準とのず れなど種々の問題があり、単純に計算結果から設定する ことは難しい。特に脂質検査では各項目毎の関連があり、 ロジック的な判定も必要となる。この点が今回もっとも 考慮した点であり、今後も定期的なデータ分析を行い、 より望ましい判定基準の設定に努めていきたい。

表1. 判定基準值および出現率
図2. TG年代別平均值 (食後 $12: 01 \sim$ )

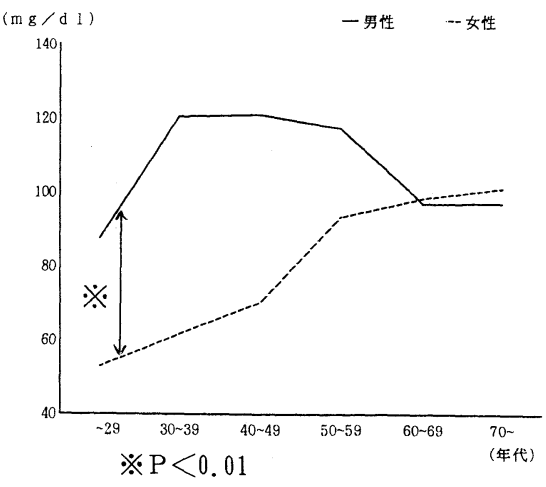

図3. $\mathrm{HDL}-\mathrm{CHO}$ 年代別平均値

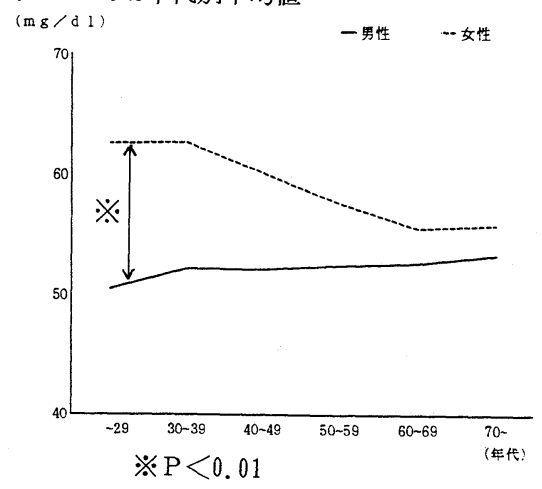

図4. 動脈硬化指数年代別平均値

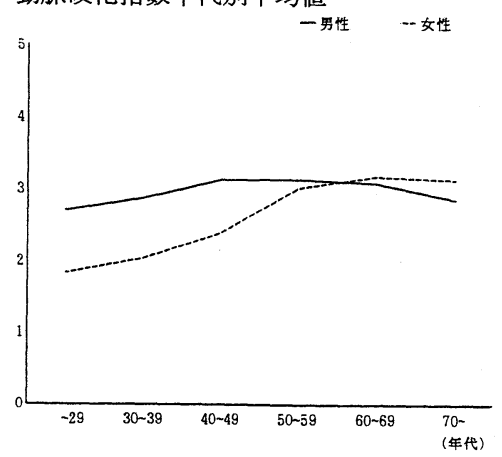

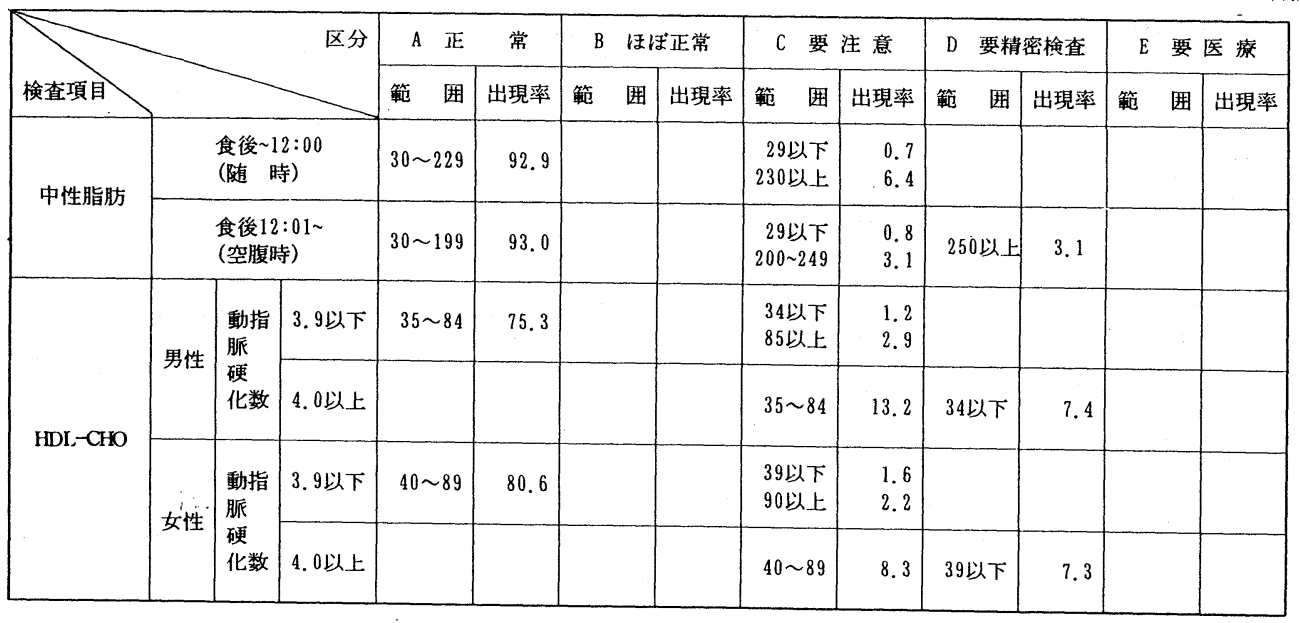


藤沼時子 木村せつ ( 埼玉県厚生連幸手総合病院健康 管理部） ○根本誠 小森谷恭子 (同検查科) 飯島潡滋 (同内科) 吉川廣和 (同健康管理部長)

〈はじめに〉

脂肪肝（以下F L ）は、今日スクリーニン グ検查として行なわれる腹部超音波検查で、 最も多く経験する症例である。

今回我々は、当院人間ドック受診者に行な った超音波検查において、F L と判定した症 例につき、肥満度及び臨床生化学的検查によ る比較、検討を行なったので報告する。

〈対象及び方法〉

当院 1 泊 2 日人間ドック受診者、90年、 603 名 (男性440名、女性163名) 、 91 年、681名(男性4 73 名、女性 20 8名)を対象とした。

まず、これらを腹部超音波の成績により、 F L 群、非F L 群に分け、更に下記条件の A 〜D 4 郡に分類した。

A 群 : 肥満度 $15 \%$ 以上で、高脂血症、肝 機能異常を認めない例。

$\mathrm{B}$ 群：肥満度に関係なく、高脂血症を認め る例。

C 群 : 肥満度に関係なく、アルコール暦、

肝機能異常により、アルコール性肝 障害と思われる例。

D群：A、B、C群のどれにも属さない例。 また、肥満に有無についても分類を行なっ た。

次ぎに、糖代謝能との関係を見るために、 空腹時血糖（以下F B S )、75gグルコー 又負荷試験（以下GT T ），による検討を行 ない異常なものについては，更に 3 種類に分 類した。
尚、超音波検查は、担当医師 3 名にて行な い、肝の点状エコー化、脈管不明暸化、肝腎 コントラストの有無により判定し、肥満度は ブローカーの公式により算出した。

\section{〈結果〉}

90 年は、603名中男性 118 名、女性 24 名、計 142 名、91 年は、681 名中 男性 140 名、女性 40 名、計 178 名を、 F L 群とし、そর以外を非F L 群とした。こ れらを A〜D群に分類した結果は次の（表 1 ） の通りであった。

\begin{tabular}{|c|c|c|c|c|}
\hline & \multicolumn{2}{|r|}{ 表 } & \multicolumn{2}{|l|}{1} \\
\hline & 9 0年 & $3(163)$ & 91 年 & $1(208)$ \\
\hline & F $\quad$ L & 非 F L & $\begin{array}{ll}\mathrm{F} & \mathrm{L} \\
\end{array}$ & 非 F L \\
\hline \multirow{2}{*}{$\mathbf{A}$} & $22 \quad(7)$ & $56 \quad(23)$ & $26 \quad(8)$ & $63 \quad(30)$ \\
\hline & $15.4 \%$ & $12.1 \%$ & $14.6 \%$ & 12. $5 \%$ \\
\hline \multirow{2}{*}{ B } & $65 \quad(12)$ & $82 \quad(21)$ & $85 \quad(24)$ & $90 \quad(3.3)$ \\
\hline & 45.7 & 17.8 & 47.7 & 17.9 \\
\hline \multirow{2}{*}{$\mathbf{C}$} & $43 \quad(1)$ & $49 \quad(1)$ & $55 \quad(0)$ & $69 \quad(2)$ \\
\hline & 30.3 & 10.6 & 30.8 & 13.7 \\
\hline \multirow{4}{*}{ D } & $12(1)$ & $274(94)$ & $12(6)$ & $281(105)$ \\
\hline & 8. 6 & 59.5 & 6. 9 & 55.9 \\
\hline & $142(24)$ & $461(139)$ & $178(38)$ & $503(170)$ \\
\hline & $23.5(14.7)$ & $76.5(85.3)$ & $26.1(18.3)$ & $73.9(81.7)$ \\
\hline
\end{tabular}

カッコ内は女性を示し各群の下段は割合 \%)を示す。

F L 群の 90 年は 53 例、9 1 年は 64 例 肥満度 $15 \%$ 以下を示し、また非F L 群の 9 0 年は 91 例、9 1 年は 107 例が逆に肥満 度 $15 \%$ 以上を示した。その詳紐は図 Iに示 す。更に、糖尿病治療中、F B S $140 \mathrm{mg} /$ dI 以上の症例を除いたものに G T T を行なっ 
た結果は表 2 に示した通りであった。そのう ち異常と判定した症例は次の 3 種に分類し、 図淸示した。

1、糖尿病治療中、F B S $140 \mathrm{mg} / \mathrm{dl}$ 以上

2 、境界型

3 、糖尿病型

尚、測定値は日本糖尿病学会の勧告值に従 つて分類した。

\begin{tabular}{|c|c|c|c|c|}
\hline 表 2 & $\mathrm{~F} \mathrm{~L}$ & 非 F L & $\mathrm{F} \mathrm{L}$ & 非 F L \\
\hline \multirow[t]{2}{*}{ 正常 } & 40 & 280 & 58 & 334 \\
\hline & $28.1 \%$ & $60.7 \%$ & $32.6 \%$ & $66.4 \%$ \\
\hline \multirow[t]{3}{*}{ 異常 } & 102 & 181 & 120 & 169 \\
\hline & $71.9 \%$ & $39.3 \%$ & $67.4 \%$ & $33.6 \%$ \\
\hline & 142 & 461 & 178 & 503 \\
\hline
\end{tabular}

\section{〈考察〉}

A 群では、F L、非 F L 群を比較した場合 大きな差は認めないが、B群 (45.7\%:17.8\%) C 群 (30.3\%: 10.6\%) と著明な差を認めた。

また、男女別のF L の割合では女性に比べ 男性は（男 26.8\% 女 14.7\%) とやや高率を みるが、C 群を除いて男女間の比較を行なっ た場合（男 $17.2 \%$ 女 $14.7 \%$ ) とその差はか なり少なくなる。これは、女性におけるアル コールの多量掑取者が少ないためと思われる。
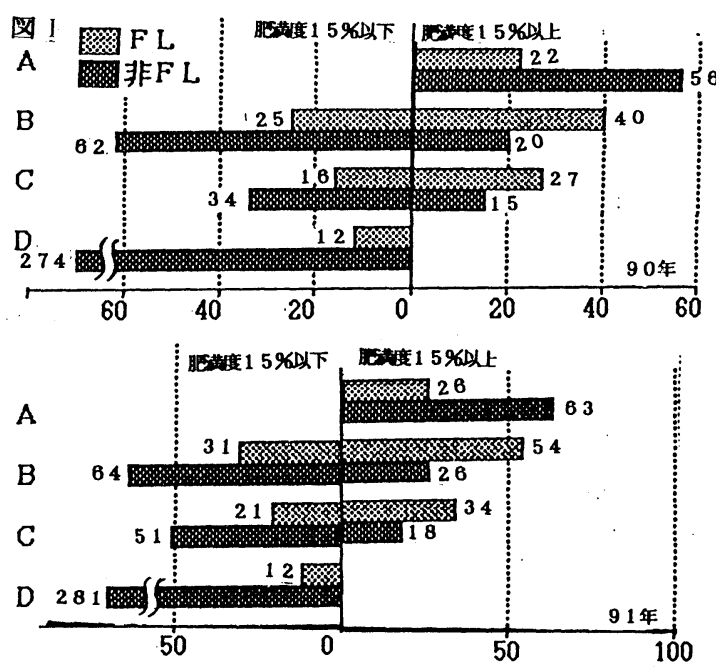

そして、肥満の有無との関係を見ると、4割 弱の症例が肥満度 $15 \%$ 末満であったにもか かわらず脂肪化を認めた。

以上のことから、肝の脂肪化には肥満の有 無はもちろんであるが、それ以外の大きな要 因として、脂質代謝異常、特に男性では、ア ルコール掑取量が重大な影響を与えているで あろうことが今回数値で示すことができたと 考えられる。

糖代謝検查の結果を見ると、F L 群は非 F し群の約 2 倍の割合で異常を示した。更に、 その異常例に中に、直ちに治療を要する糖尿 病と判断されたものは、約 3 倍以上の割合で 認めた。この事からも、FLと判定した症例 について、F B Sなどが正常域であったとし ても、GT T を行なうことにより潜在的な糖 尿病が発見される可能性は非常に高い上思わ れる。

目 II
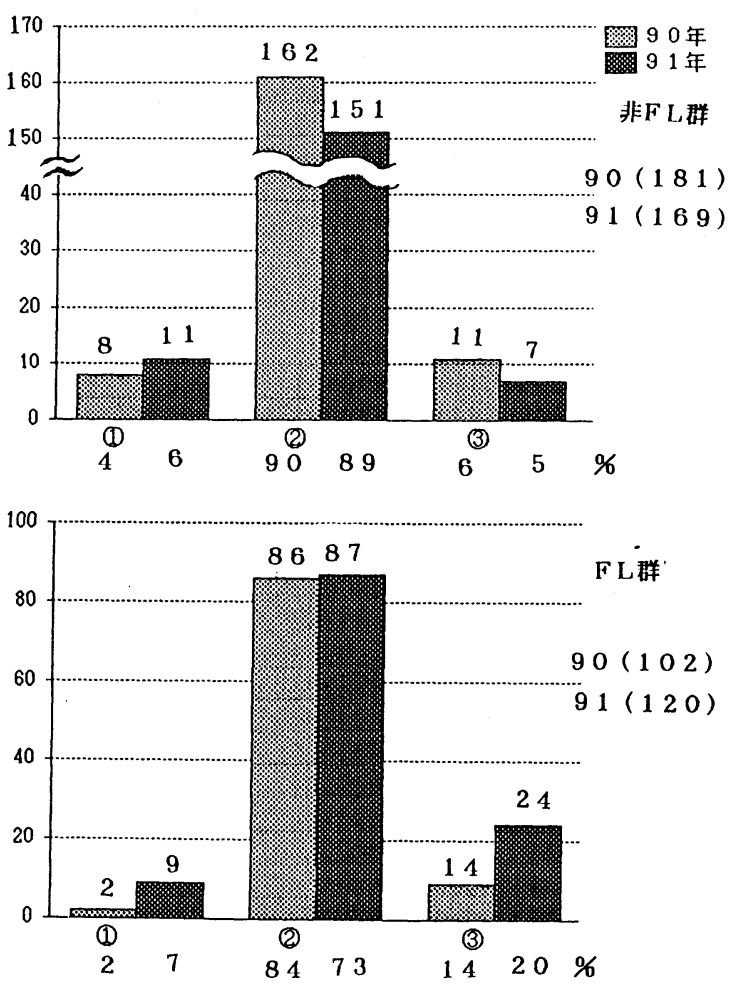


\title{
秋田県湖東地区に打ける早朝総合健診実施報告
}

$\bigcirc$ 松村董子菊地優子伊藤信子石井秀樹

\author{
石川チサ子蒔田光郎
}

(秋田県厚生連湖東総合病院保健活動室)

\section{〈はじめに>}

当地区に打ける地域の住民検診は、単独検 診からセット化の傾向にあり、当院において 屯、昭和 60 年度より老人保健法の基本健診、 がん検診、及び結核検診をセットした早朝総 合健診を 4 町で実施している。

その中の 1 つ、 $\mathrm{S}$ 町は昭和 62 年度より早朝 総合健診として基本健診、胃がん検診、子宮が 几検診、乳がん検診、結核検診を。昭和 63 年 度からは大腸検診、肺がん検診をプラスし、 より充実した検診内容をめざしている。

今回我々は、 $\mathrm{S}$ 町の総合健診開始前と後の 受診者数の比較検討したので、報告する。

\section{$<$ 方 法 $>$}

$\mathrm{S}$ 町の健診受診者を対象に、早朝総合健診 開始前と後の基本健診、がん検診の受診者数 の推移、及び開始前の昭和 58 年度、開始直後 の昭和 62 年度之昨年の 3 年分の性別、年代別 の受診状況について分析した。

尚、早朝総合健診の方法については、第 1 報から第 3 報で、報告したと抲りである。

〈結果及び考察〉

1 ) 昭和 62 年度に早朝総合健診となってから の、基本健診、がん検診ともに受診者数は 著明に増加している。セットとなり、一度 で全部の検診が受けられるとと、行政側の P R が十分であったとと、推進員の活躍が 大きかったてと。健診の流れがスムーズで 住民に好評であったてとが考えられる。

2 ) 肺がん検診に関しては、平成 3 年度に急 激に増加している。乙れは、日中来院して
受ける方式から、結核検診と同一のフィル ムによる判定と、当日の検体（喀疢）の回 収により、一度で終われるようになったた めと思われる。

3 ）性、年代別の比較では、当初働き盛かり の男性、40〜50才代の年令層の急増が予想 された。しかし実際には、性別、年代別に 関係なく、全体的に同じ割合で増加してい る。この理由として、働く婦人の増加によ り、性差がなくなったてと、町の住民の年 令構成のかたより、又は、早朝総合健診に 対する住民のニーズが我々の予測と違うと ころにあったのではないかと考える。 〈まとめ>

基本健診、がん検診ともに、早朝総合健診 が開始されてから増加しており、一日ですべ てが終了できる手軽さ、仕事前にできる便利 さが住民の好評を得ているのではないかと考 える。乙れは、肺がん検診が、日中来院して 行う方式から、早朝総合健診の中で一度でで きるようになり、受診者が急増したことから あ、言えるのではないだろうか。しかし、性 別、年代別では、40～50才代の働き盛かりの 男性の増加を予想したが、年代別の比率では ほとんど変化がみられなかった。性別あ同様、 男性と女性の割合にはほとんど差はみられな い。乙れは、S 町の年令構成によるものか、 住民の健診に対する意識が、職業の有無にか かわらず全体的に高いためか、住民の早朝総 合健診に対するニーズが、我々の“出勤前に 受けられる健診”という予測と違うとてろに 
あるのか、今後の課題となったが、事業所検 診の中での健診受診の増加む一因としてあげ られると推察された。
早朝総合健診は、住民や行政側からあ、好 評を得ており、今後あ住民のニーズに応えら れるよう努力していきたい。

\section{検診受診者数の推 移}

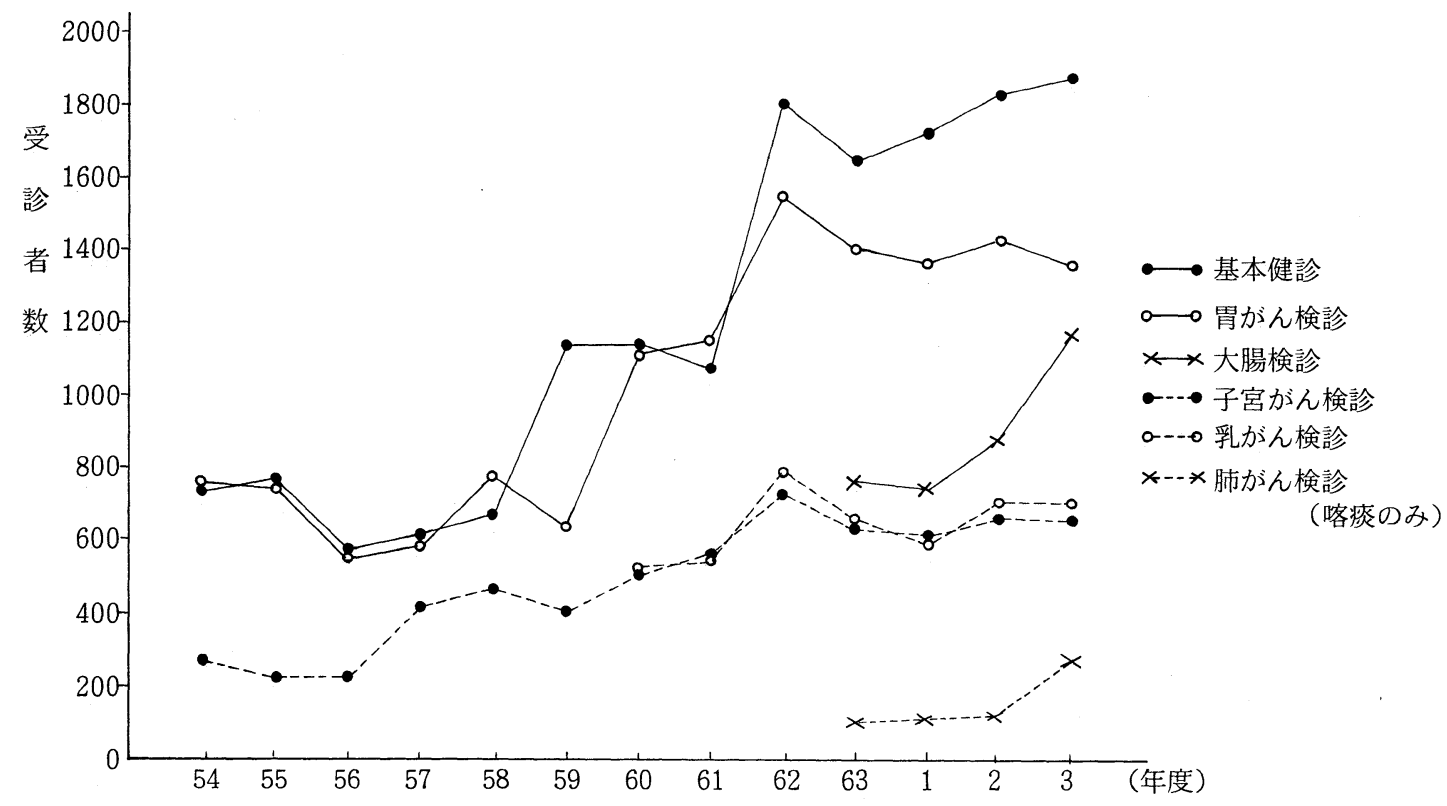

昭和町 性別 - 年代別検診受診者数

\begin{tabular}{|c|c|c|c|c|c|c|c|c|c|c|c|c|c|}
\hline & \multicolumn{6}{|c|}{ 男 } & \multicolumn{6}{|c|}{ 女 } & \multirow[b]{2}{*}{ 合計 } \\
\hline 年代 & 30 & 40 & 50 & 60 & 70 & 計 & 30 & 40 & 50 & 60 & 70 & 計 & \\
\hline S 58 & $\begin{array}{c}28 \\
(13.4)\end{array}$ & $\begin{array}{c}45 \\
(21.5)\end{array}$ & $\begin{array}{c}62 \\
(29.7)\end{array}$ & $\begin{array}{c}56 \\
(26.8)\end{array}$ & $\begin{array}{l}18 \\
(8.6)\end{array}$ & $\begin{array}{c}209 \\
(30.8)\end{array}$ & $\begin{array}{c}46 \\
(9.8)\end{array}$ & $\begin{array}{c}111 \\
(23.7)\end{array}$ & $\begin{array}{c}195 \\
(41.6)\end{array}$ & $\begin{array}{c}103 \\
(21.9)\end{array}$ & $\begin{array}{c}14 \\
(3.0)\end{array}$ & $\begin{array}{r}469 \\
(69.2)\end{array}$ & 678 \\
\hline S 62 & $\begin{array}{c}136 \\
(22.7)\end{array}$ & $\begin{array}{c}125 \\
(20.9)\end{array}$ & $\begin{array}{c}135 \\
(22.6)\end{array}$ & $\begin{array}{c}139 \\
(23.3)\end{array}$ & $\begin{array}{c}63 \\
(10.5)\end{array}$ & $\begin{array}{c}598 \\
(32.9)\end{array}$ & $\begin{array}{c}220 \\
(18.0)\end{array}$ & $\begin{array}{c}296 \\
(24.2)\end{array}$ & $\begin{array}{c}393 \\
(32.2)\end{array}$ & $\begin{array}{c}252 \\
(20.6)\end{array}$ & $\begin{array}{c}61 \\
(5.0)\end{array}$ & $\begin{array}{l}1,222 \\
(67.1)\end{array}$ & 1,820 \\
\hline $\mathrm{H} 3$ & $\begin{array}{c}118 \\
(18.3)\end{array}$ & $\begin{array}{c}174 \\
(26.9)\end{array}$ & $\begin{array}{c}115 \\
(17.8)\end{array}$ & $\begin{array}{c}173 \\
(26.8)\end{array}$ & $\begin{array}{c}66 \\
(10.2)\end{array}$ & $\begin{array}{c}646 \\
(34.2)\end{array}$ & $\begin{array}{c}205 \\
(16.5)\end{array}$ & $\begin{array}{c}301 \\
(24.3)\end{array}$ & $\begin{array}{c}347 \\
(28.0)\end{array}$ & $\begin{array}{c}211 \\
(17.0)\end{array}$ & $\begin{array}{c}77 \\
(6.2)\end{array}$ & $\begin{array}{c}1,241 \\
(65.8)\end{array}$ & 1,887 \\
\hline
\end{tabular}

H 3 年度 検診結果

\begin{tabular}{|c|c|c|c|c|c|c|c|}
\hline \multicolumn{2}{|c|}{ 検診項目 } & 受診者数 & 要精検者数 & 要 精 検率 & 精検受診者数 & 精検受診率 & 発 見 癌 \\
\hline 胃 & 癌 & 1,377 & 299 & 21.8 & 223 & 74.6 & 1 \\
\hline 子 宮 & 癌 & 657 & 4 & 0.6 & 3 & 75.0 & 0 \\
\hline 乳 & 癌 & 704 & 15 & 2.13 & 7 & 46.7 & 0 \\
\hline 肺 & 癌 & $\begin{array}{r}2,502 \\
(266)\end{array}$ & 139 & 27.7 & 111 & 79.0 & 3 \\
\hline 大 & 腸 & 1,177 & 37 & 3.14 & 15 & 40.5 & 0 \\
\hline 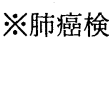 & S & & & & $\begin{array}{l}\text { 異常なし } \\
\text { 要指導 }\end{array}$ & $\begin{array}{r}21.7 \% \\
8.8 \%\end{array}$ & $\begin{array}{l}11.1 \% \\
58.4 \%\end{array}$ \\
\hline
\end{tabular}




\section{○慈幸弘樹、平山純二、川口篤則、五百崎美帆子 中野好夫、南條輝志男 \\ (国保日高総合病院第2内科農村医学研究室)}

\section{【目的】}

1,5-anhydroglucitol(1,5AG)はブドウ糖 と類似したポリオールである。最近 $1,5 \mathrm{AG}$ は、 $\mathrm{HbA}_{1} \mathrm{c}$ やフルクトサミンと同様に血糖コント ロールの指標として注目されている。今回 我々は、検診時の糖尿病スクリーニングの指 標として $1,5 \mathrm{AG}$ が有用であるか否かを検討し た。

\section{【対象および方法】}

平成 3 年 10 月より平成 4 年 7 月の間に当院人 間ドックを受診し肝腎障害を認めなかった 107名（男子93名女子14名）を対象とした。 対象者に経口 $75 \mathrm{~g}$ ブドウ糖負荷試験を行う とともに $1,5 \mathrm{AG} 、 \mathrm{HbA}_{1} \mathrm{C}$ を測定した。WH0の診 断基準を用いて糖尿病群、IGT群、健常者群 の3群に分け、3群間の1,5AGについて比較検 討した。また、健常者群のmean \pm 2 SDをカッ トオフ值とし、1, $5 \mathrm{AG} 、 \mathrm{HbA}_{1} \mathrm{C} 、$ 空腹時血糖 (FPG)の糖尿病スクリーニングにおける感度、 特異度を比較した。さらに、この3指標を組 み合わせることによる感度、特異度も検討し た。なおFPGはglucose oxidase法、HbA $1 \mathrm{C}$ はHPLC法、1, 5AGは「A, G(1,5Anhydroglucitol) 測定キット」（日本化薬）を使用 した。結果はmean \pm SEで表し有意差検定には Student's t-testを用いた。

\section{【結果】}

(1) 各群の平均年齢は糖尿病群 $51 \pm 1.2$ 歳、 IGT群 $52 \pm 2.3$ 歳、健常者群 $48 \pm 3.0$ 歳であ り各群間に有意差は認めなかった。

(2) 糖尿病群の $1,5 \mathrm{AG}$ 值 $(5.7 \pm 1.44 \mathrm{~g} / \mathrm{ml})$ は他の2群に比し有意 $(\mathrm{p}<0.01)$ に低值であっ た。IGT群の $1,5 \mathrm{AG}$ 値 $(23.3 \pm 2.07 \mu \mathrm{g} / \mathrm{ml})$ は
健常者群 $(29.9 \pm 1.01 \mu \mathrm{g} / \mathrm{ml})$ に比し有意 （p<0.01）に低值であった（図1）。 $\mathrm{HbA}_{1} \mathrm{c}$ 值 も同様に3群間で有意差を認めた（図2）が、 FPG値では健常者群、IGT群の間に有意差は認 められなかった（図3）。

(3) 1, $5 \mathrm{AG}$ टHbA $\mathrm{C}$ の間には、 $\mathrm{r}=-0.54$ の有 意な負の相関がみられた（図4）。

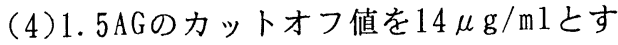
ると、感度、特異度はそれぞれ $88.8 \%$ 、 92.9\%であった。HbA1cのカットオフ值5.5\% で、感度、特異度はそれぞれ77.8\%、91.9\% であった。また、FPGのカットオフ值は $110 \mathrm{mg} / \mathrm{dl}$ で、感度、特異度はそれぞれ $88.8 \%$ 、 91.9\%であった（表1）。 さらに、1, $5 \mathrm{AG}$ と $\mathrm{HbA}_{1} \mathrm{c}$ とPPGの指標のうち2 つの指標を “and”で組み合わせて、感度、 特異度を検討すると、1, $5 \mathrm{AG} 、 \mathrm{HbA}_{1} \mathrm{C} 、 \mathrm{FPG}$ 単 独の時に比べて感度はわずかに低下したが、 特異度は高くなった（表2）。さらにカット オフ值を健常者のmean $\pm 1.5 \mathrm{SD}$ として同様 に2つの指標を “and”で組み合わせみると単 独で判定する場合と較べて感度は同等で特異 度は上昇していた（表2）。

\section{【考察】}

$1,5 \mathrm{AG}$ 值は $\mathrm{HbA}_{1} \mathrm{c}$ 值と同様に糖尿病群、IGT 群、健常者群で有意差を認め、同程度の感度、 特異度を示した。糖尿病スクリーニングに関 しては、1, $5 \mathrm{AG}$ は $\mathrm{HbA}_{1} \mathrm{c}$ と同様に有用と思われ る。

1, $5 \mathrm{AG}$ はbbA1 $\mathrm{c}$ と負の相関を示していたが、 $1,5 \mathrm{AG}$ 值が低い範囲では $1,5 \mathrm{AG}$ の変動に比べ て $\mathrm{HbA}_{1} \mathrm{c}$ の変動の方が大きかった。血糖コン トロールが悪い状態では $1,5 \mathrm{AG}$ は測定感度以 下となってしまい、HbAlcの方が病態をよく 
表すと考えられる。

一般にカットオフ值を正常値に近づけると 感度は上がり特異度は下がる。2つの指標を “and”で組み合わせる事により感度を落と さずに特異度を上げられると考えられる。今 回もカットオフ值をmean $\pm 1.5 \mathrm{SD}$ として、感 度、特異度を検討したがほぼ予想どおりの結 果であった。特にHbA $1 \mathrm{c}$ と $1,5 \mathrm{AG}$ 組み合わせ た時の特異度は高かった。しかし、対象者が 約 100 名と少なく、さらに糖尿病患者が9名と 少なかったので、詳細な検討ができなかった。 今後症例数を増やし、感度、特異度とも高く なるカットオフ值をもとめ、糖尿病スクリー ニングにおける有用性を検討したい。

\section{【結語】}

糖尿病スクリーニングにおいて $1,5 \mathrm{AG}$ は $\mathrm{HbA}_{1} \mathrm{c}$ と同程度に有用であった。
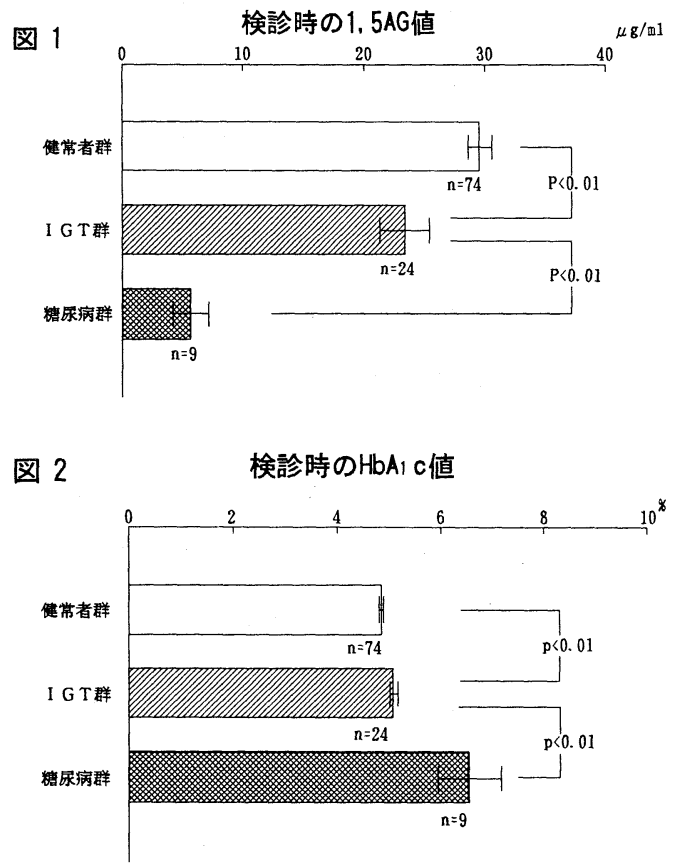

図 3 検䛦時の空腹時血糖

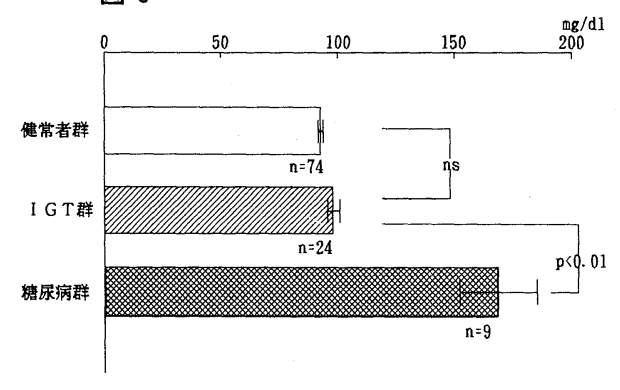

図 $4 \quad 1,5 A G$ とbA1cの相関

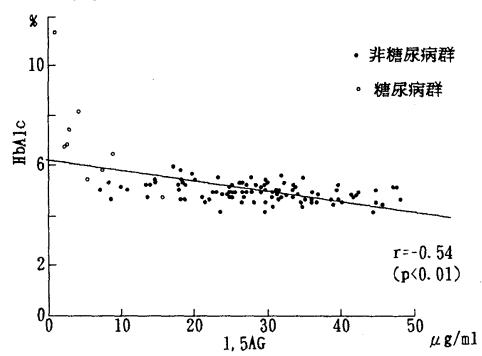

表 1 糖尿病スクリーニングの感度、特異度

\begin{tabular}{|c|c|c|}
\hline & 感 度 (x) & 特罢度 (x) \\
\hline 1. $\underset{(\langle 14 \mu \mathrm{g} / \mathrm{m} 1)}{\mathrm{AG}}$ & 88.8 & 92.9 \\
\hline $\mathrm{Hb} \mathrm{A} 1(15.58)$ & 77.8 & 91. \\
\hline$F P G_{0}$ & 88.8 & 91.9 \\
\hline
\end{tabular}

表 2 各指標の組み合わせ感度、特異度

\begin{tabular}{|c|c|c|}
\hline & 留 $\quad$ 度 & 特 賈 $($ ( ) \\
\hline $\begin{array}{l}1.5 A G \text { and } \mathrm{HbAlc} \\
(\langle 14 \mu \mathrm{g} / \mathrm{m}|)(>5.5 x)\end{array}$ & 77.8 & 100 \\
\hline $\begin{array}{l}1.5 \mathrm{AG} \text { and } \mathrm{FPG} \\
(\langle 14 \mu \mathrm{g} / \mathrm{mI})(1) 110 \mathrm{mg} / \mathrm{dl})\end{array}$ & 88.8 & 97.9 \\
\hline $\begin{array}{l}\text { FPG and } H b A / c \\
(>110 \mathrm{mg} / \mathrm{d} 1)((5.5 \%)\end{array}$ & 77.8 & 97.9 \\
\hline $\begin{array}{l}\text { 1. } 5 A \mathrm{G} \text { and } \mathrm{HbAlc} \\
(\langle 16 \mu \mathrm{g} / \mathrm{mI})(>5.4 x)\end{array}$ & 88.8 & 98.9 \\
\hline $\begin{array}{l}1.5 \mathrm{AG} \text { and } \mathrm{FPG} \\
(\langle 16 \mu \mathrm{g} / \mathrm{ml})(\rangle 106 \mathrm{mg} / \mathrm{dl})\end{array}$ & 88.8 & 96. \\
\hline $\begin{array}{l}\text { FPG and } \mathrm{HbAlc} \\
(>106 \mathrm{mg} / \mathrm{dl})(>5.4 x)\end{array}$ & 88.8 & 94. \\
\hline
\end{tabular}


$1 \mathrm{~A} 07$ 渥美半島における潜水夫人間ドックの結果について

愛知県厚生連渥美病院

$\begin{array}{rrrrrr}\text { 鈴江 } & \text { 孝昭 } & \text { 山田 } & \text { 直樹 } & \text { 中根 健 } & \text { 黒江幸四郎 } \\ \text { 篠田 } & \text { 昌一 } & \text { 田川 } & \text { 信正 } & \text { 渡邊 晃祥 } & \end{array}$

渥美半島には、ミル貝を採ることを職業と する潜水夫が 85 名いて、その内 64 名（約 $74 \%$ ) が潜水病の既往歴がある。我々は、

潜水夫の健康管理を目的として、潜水夫人間 ドックを 1991 年に実施し、その受診者は 85 名全員であった。

\section{1 , 検查項目} るものが多かった。その病型の割合として は、全体的には、ベンスがやはりもっとも多 く 85 人中 64 人 $(71 \%)$ が経験したこと になる。皮唐型の経験者は意外と少なく 85 人中 30 人 $(35 \%)$ であった。又、脳型、 春抯型なとの重症の潜水病を経験した者も 1 9 人（22\%）いた。

2 ) 潜水深度と潜水病既往との関係（2表） に潜水病について等) (2身体測定（身重、体 重) (3)循環器系（血圧、心電図）(4)胸部 $\mathrm{X}$ 線 (5)肺機能（肺活量、1 秒率）(6)尿㭘査（蛋 白、糖、ウロビリノーゲン、尿潜血) (7)血液 検査 (赤血球、白血球、血小板、血清鉄、 $\mathrm{H}$ $t 、 H ~ b 、 C R P 、 R A)(8)$ 生化学的検査 （総蛋白、GOT、GPT、T T T A 1 P、HBS 抗原、蛋白分画、FBS、へモ グロビンA1C、尿酸、総コレステロール、 トリグリセライド) (9)聴力検査（1000 H $\mathrm{z} \cdot 4000 \mathrm{~Hz}$ ) (10骨X線写真（而側上 腕骨上部、両側上腕骨下部、両側大腿骨上 部、両側大腿骨下部、両側脛骨部上部、骨 盤 )

受診者の年齢は、20歳代 21 名、30歳代 17 名、40 歳代 30 名、50歳代 16 名、 60 歳代 1 名で、平均年齢は 39.7 歳で あった。

\section{2 , 問診の結果}

1) 潜水歴と潜水病既往について

1 表のこととく、1〜 4 年でも $76 \% 、 5$ 年〜 9 年 $94 \% 、 10$ 年〜 19 年 $67 \% 、 20$ 年 以上 $70 \%$ と、いずれも潜水病の既往を有す

潜水深度が大きくなるにしたがって、潜水病 既往を有する者が多かった。特に $15 \mathrm{~m}$ を越 える潜水夫では、全体の $90 \%$ が潜水病の既 往を有していた。

3) 潜水時間と潜水病既往について 4 時間、5 時間、 5 時間以上どれも $75 \%$ 前 後と有意の差はなかった。

4 ) 潜水病の既往の有無と脂肪代謝 脂質（総コレステロール、トリグリセライ ド）の結果で、潜水病の既往を有する者と、 それを有しない者を比較すると、既往を有し ない者の要精検率 $14 \%$ に対して、既往を有 する者は $34 \%$ と高かった。これは、脂肪に は、チッ素ガスが血液に比べて 5 倍溶解する こと、また、脂肪は潜水病発症の際、脂肪栓 塞の発症源となることなとの理由から、一般 的に高脂血症を有する潜水夫は潜水病に䍜患 しゃすいといわれている。

\section{5 ) 骨X 線の結果}

85 名中何らかの骨病変を認めたのは、64 \%54名（６６力所）であった。3表のこと く、A ・関節面障害型 B・骨頭、䅡部、骨 幹部障害型 $\mathrm{C} \cdot$ 島状硬化とに分類すると、 
A 型 5 名 $(9 \%) 、 B$ 型 32 名 (5 9\%)、 C 型2 9 名（54\%）であった。

6 ) 骨病変の好発部位 (4 表)

骨病変の部位は、上腕骨上部（３６.4 $\%$ ）、大腿骨上部（３６４％)，脛骨上部 （9\%）、大腿骨下部、骨盤、上腕骨上部が （6\%）の順であった。

7 ) 潜水歴と骨病変

骨病变発生率は経験年数とともに増加し、1 $\sim 4$ 年 $47.1 \% 、 5$ 年 9 年 $50 \% 、 10$ 年〜 19 年 $70 \% 、 20$ 年以上 $78.3 \%$ で あった。

\section{8 ）ベンスと骨病変}

骨病変を有する 54 名中 42 名（78\%）が ベンズ経験者であった。又ベンズ発生部位と 骨病変との関係は、一致するものは $37 \%$ で、一致しないものが $63 \%$ もっった。

9 ) まとめ

潜水病既往を有する症例中には、病院で治療 を受けずに、放置あるいは自己再圧（ふか し）を行っているものが 64 名中 25 名（3 $9 \%$ ）もいた。また、骨病変を有するものと 有しないものを比較すると、骨病变を有しな い症例は、 $71.5 \%$ が病院で治療をうけて いる。これにたいして、骨病変を有するもの は44\%と少なかった。これは、病院におけ る再圧療法が骨壊死に对して有用であったと と考えられる。

減压性骨壊死に対して、現在のところ決定的 な予防法はないか、減压によって起こる気泡 形成および続発する凝固系（血小板など）の

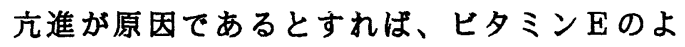
うな血小板凝集阻害剤を投与することが有用 と思われる。

労㒋衛生上の対応としては早期発見、早期治 療が重要である。骨壊死の最初のX線写真上
の兆候は、諸家の報告によれば高気圧への暴 露後、約 $4 \sim 5$ 力月で起こるが、病変が明確 になるのは、約 2 年半後であると言われてい るので、 1 年ことの X 線写真検查を最低約 3 年間継続することが重要と思われる。

1 表 潜水歴と潜水病既往

\begin{tabular}{|c|c|c|}
\hline & 潜水者 & 既往有り \\
\hline $1 \sim 4$ 年 & 17 & 13 \\
\hline $5 \sim 9$ 年 & 18 & 17 \\
\hline $10 \sim 19$ 年 & 27 & 18 \\
\hline 20 年 & 23 & 16 \\
\hline
\end{tabular}

2 表 潜水深度と潜水病既往

\begin{tabular}{|r|r|r|}
\hline & 潜水者 & 既往有り \\
\hline$\sim 14 \mathrm{~m}$ & 21 & 8 \\
\hline $15 \sim 19 \mathrm{~m}$ & 38 & 31 \\
\hline $19 \sim 24 \mathrm{~m}$ & 24 & 23 \\
\hline $25 \mathrm{~m} \sim$ & 2 & 2 \\
\hline
\end{tabular}

3 表 骨病変のX線分類
A. 関節面障害型
A 1. 分節状硬化
A 2. 線状硬化
A 3. 塊状硬化
A 4. 離断線形成
A 5. 関節面陷没
A 6 。胃関節症
B，骨頭、頸部、骨幹障害
B 1. 限局性石灰化
B 2. 不規則石灰化
B 3. 限局性脱灰化
C. 島状硬化

\begin{tabular}{|c|c|c|}
\hline \multicolumn{2}{|l|}{ 部 位 } & 骨病恋症例数 \\
\hline \multirow{3}{*}{ 上腕骨上部 } & 右 & 11 \\
\hline & 左 & 11 \\
\hline & 両側 & 2 \\
\hline \multirow{3}{*}{ 上腕骨下部 } & 右 & 2 \\
\hline & 左 & 2 \\
\hline & 両側 & 0 \\
\hline \multirow{3}{*}{ 大腿骨上部 } & 右 & 9 \\
\hline & 左 & 10 \\
\hline & 両側 & 5 \\
\hline \multirow{3}{*}{ 大腿骨下部 } & 右 & $\overline{0}$ \\
\hline & 左 & 3 \\
\hline & 両側 & 1 \\
\hline \multirow{3}{*}{ 脛骨上部 } & 右 & 4 \\
\hline & 左 & 2 \\
\hline & 両側 & 0 \\
\hline \multirow{3}{*}{ 骨 盤 } & 右 & 2 \\
\hline & 左 & 2 \\
\hline & 両側 & 0 \\
\hline
\end{tabular}




\section{A08 土浦協同病院における院内がん登録}

$\bigcirc$ 真田勝弘, 井田純子, 成瀬亨子, 木瀬弘, 一宮和夫, 田沢潤一, 川田健一, 登内真

(土浦協同病院㤎んセンタ一)

はじめに：がん登録とは，がん患者について 信頼性があって利用価値のある必要最小限の 情報を収集し，記録保存することであり，国 際登録, 全国登録, 地域登録, 院内登録があ る。院内がん登録は，病院におけるがん診療 機能を客観的に評価し，その強化計画の資料 を得るとともに，病院の対がん活動を活発に する目的で行なうがん登録である。

われわれは，1991年10月から土浦協同病院 院内がん登録を開始したので,これまでの経 過についてのべるとともに，いくつかの問題 点について考察する。

動機と開始までの経過：院内がん登録が有意 義なことは自明であるが, 業務量の增大を伴 う新しい事業を開始するに当たっては，十分 な動機づけが必要であった。茨城県では, 県 の策定した総合がん対策の一つとして，4 か 所に地域がんセンターを設置するてとになり， 土浦協同病院むその一つとして指定されたが， その際の条件の一つとして院内がん登録を実 施するてとが求めら机ていた。ての時点で登 録の準備を開始し，1991 年 10 月の茨城県の地 域がん登録の開始に合わせて, 実際の登録專 業を開始することができた。

登録窒の人的・物的褠成：独立したがん登録 室と登録要員を確保することは困難であり， 診療録室の一部を利用するととにした。診療 録室では 3 人の瞕員で全科の退院患者の診療 録をパソコンを利用して管理していたが，新 たにがん登録用のパソコンを設置し，職員は 1 人堌員して 4 人で登録業務す兼任するよう
にした。

登録の対象患者：最初から病院で診療するす べてのがん患者を対象とするのは困難なため， 入院して退院したがん患者のみを登録の対象 とした。具体的には，退院時に提出された荆 療録の記載疾患名を ICD-9 (international classification of diseases）によって分類 し，その 140 から 208 まで，および 230 から 234 までに該当する疾患の患者とした。 収集すべき情報の項目：三輸らの作成した標 準登録票の標準 I 型に収録された項目を収集 することを原則とした。乙れは，個人識別， 診断, 既往歴, 治療, 予後, 死亡, の各項目 からなり，院内がん登録で収集すべき必須項 目のすべてを含んでいる。当初の試行段階で は, 三輪胃がん登録研究所から標準 I 型の登 録票をわけて頂き，そのまま記入してみた。 その後, 茨城県の地域がん登録での届出票が できあがり，届け出の項目が定まった時点で， それに合わせて修正を加え，院内登録からコ ンピューター処理だけで県の地域登録に対応 できるようにした。

情報収集の実際：土浦協同病院悪性新生物院 内登録票はB5 版のカードで, 表が登録票, 裏 が記入のための注意事項となっている。初回 入院例之再発例再入院例の書き方の相違, 他 科へ転科する際の記入の仕方などは，注意事 項に記載されている。乙のカードはすべての 病棟に配布してあり, 該当する患者が退院し たときは，退院診療録ととあに病歴室に提出 する。カードが提出されない場合には，病歷 
室から主治医に提出を求めることになる。 登録業務の現状 :

1.がん患者の把握：現在は登録の対象を退院 患者に限っている。退院時に提出された診療 録にICD-9で分類して，140から 208 までお よび 230 から 234 までの疾患名がついている 場合にはカードの提出を求める。副病名とし てついている場合には主治医に問い合わせて， 今回の入退院ががんとは無関係であれば対象 としない。

2.入力作業：登録票の記載にもとづいてパソ コンにインプットする。明らかなミスや矛盾 は訂正し, 記載漏れや疑問点はカルテを参照 して確認する。登録室で処理できない場合に は主治医に問い合わせる。

3. 出力作業: 現在, 出力作業はまだ行なって いないが, 基本的統計の作表（部位・性・年 齢階級別 - 診断方法別 - 治療方法別 - 進行度 別の登録がん患者数），各種の患者リスト， 特定の作表, 生存率の計算を予定している。 4. 追跡調査：まだ行なっていない。登録開始 後 1 年を過ぎた時点で開始する予定である。

5.地域がん登録への対応：1991年 10月から始 められた茨城県地域がん登録へ対応して登録 表を提出している。

いくつかの問題点および考察：院内がん登録 が有意義であるのは自明であるが, 病院の収 益に直接的には寄与しないうえに，場所と人 と物と費用を要し，またすべての医師に負担 をかけるので，始めるのは容易ではない。わ れわれの場合は，茨城県の総合がん対策に対 応しなければならないという一つの強制力が 働いたが, 準備の開始から始動までには約 2 年を要した。乙の間に数回に亘っての会議で の説明と, 事務局との折衝を要した。

登録表の作成に当たっては, 厚生省がん研
究助成金による研究班, 院内がん登録小委員 会（代表：三輪潔）編集の「院内がん登録一 その基礎と実際一」を参考にし，同書にある 「標準 I 型」をモデルとした。県の地域登録 に対応するため多少の修飾を加えたが, 基本 的な骨組みは变えていない。パソコンのソフ トは業者に注文した。

登録の対象患者は, 外来患者も含めるのが 理想的ではあるが, 実際問題として外来患者 を遺漏なく登録することは困難である。われ われの病院では, 退院患者のカルテは全科に わたって中央病歴室で管理する体制ができて いるので，入退院した患者は遺漏なく登録す ることができる。病歴の中央管理は, 院内が ん登録のための基本的要件である。

最後に, 実際に提出された院内登録票の記 入に当たっての問題点を挙げる。

(1)カードの不備 : カードはすべての悪性腫瘍 に最大公約数的に対応するため, 個々のケ一 スに対しての不備が免れない。各項目に, 不 明, 該当なし, その他, の項を設けて対処し た。(2)記入者の誠意：カードの記載は担当医 にとっては業務量の増大である。記入に際し ての注意事項を見ずに書く人があり, 必要事 項の記載漏れや，不正確な記載があり，登録 室で記入や訂正の行き届かない場合があり得 る。(3)個人的な見解の相違: 治療が治瘉的か 非治癒的加, 絶対的加相対的か, 退院時の転 㷌が治癒か軽快か, などの点で個人の見解の 差がある。症例によってのばらつきがあり得 るほかに, 院内で転科した場合には同一症例 で二つ以上の見解の出る場合がある。日付 の不確定：初発年月日は確定できない場合が 多い。診断確定年月日には主観が入り得る。 (5)その他: 重複癌, 多発癌, 多重癌は定義が 明らかでないとてろがある。 


\title{
看 護 I
}

1B01

\author{
自宅で出来る牽引の退院指導
}

\section{〜タビ牽引患者へのパンフレット作成〜}

○熊田典子、佐々太早苗、渡辺裕子、小松かづ子

三菻重子、工藤つぎ子、加藤サク、須田チエ

(秋田県厚生連 由利組合総合病院)

〔はじめに〕

変形性股関節症とは、骨がすり減ってしま うことによりおこる疾患で、完治せず、継続 した治療が必要である。保存療法のひとつと して、介達率引が広く用いられており、当病 棟でも、以前スピードトラック牽引を行なっ ていた。しかし、トラックバンドのずれや皮 周損傷がみられたり、1人では装着困難であ

そこで、十数年前から市販のタビを利用し た足袋率引を考案し、自宅での率引が行ない やすくなった。そして、その方法を覚えるた め、1 週間位入院する患者が増えてきた。（ 図 1)

退院後、自宅で牽引する場合、要領を得ず 患者からの問い合わせがあり、退院指導が充 分な内容とは言えなかったのではないか、と 考えた。

そこで、看護婦が同じレベルで一貫した指 導を行ない、少しでも患者のたゆになる充実 したものにしていくことを目的に、今回の研 究に取り組んだ。

\section{〔調查期間〕}

平成元年 4 月～平成 3 年 7 月

\section{[調查対象]}

変形性股関節症患者 10 名 (入院患者)

男性：1名、女性：9名

30 代：1名、50代：6名、60代：2 名、

70 代：1名

\section{[調查方法]}

電話アンケート及び家庭訪問

〔結果及び考察（表1）〕

退院指導は患者全員が受けていたが、4人 は指導内容が充分理解出来なかった、という 結果がでている。その理由として、「指導が 具体的でなかった」「必要性はわかるが、方 法がわからない」「方法を家族にも説明して 欲しかった」なぞがあげられた。

自宅での軹引は、9名が行なっていたが、 どのように牽引していいかイメージがつかめ ず、道具の準備や工夫に戸惑う人が多くみら れた。

率引により効果ありと答えた人は 8 名、残 り 2 名は効果なし、と答えている。このこと は、足袋牽引が痛みの軽減に有効であるとい うことを示している。

牽引するための工夫は、9名全員が行なっ ていた。苦労した点として、「布団からべッ トに換えた」「部屋の改造」「ベットの工夫 「牽引器具の土夫」などである。

患者の希望としては、「具体的な説明が欲 しい」「捦のかからない方法」「手軽にで きる方法」「家庭ですぐ活用できる方法」「 口頭だけの説明だったので、パンフレットな ど残るものがあればよい」「率引器具の模型 や写真があればよい」なぞがあげられた。

以上の結果をもとに、絵を多くとり入れ、 身近なものを利用した数種類の率引方法を紹 介し、さらに日常生活の注意事項を盛り込み パンフレットを作成した。（図 2 )

パンフレットの内容を評価する一方法とし て、対象の患者にパンフレットを送り、再度 電話アンケートをした。

その結果、「指導された内容が文字として 
残っているのでわかりやすい」との声が聞か れた。また、わからなくなった時、読み返す 事ができるという安心感があり、パンフレッ ト圭全員の患者が保管していた。

今回の調查では、退院指導はされたものの 自宅での星引に戸惑った人が、予想通り多い ことを知った。

今までは、基準化されたものがなく、指導 内容が一定しなかったが、今回「退院パンフ レット」という紙面化したものができたこと で、一貫した指導を行なうことができた。

指導するにあたり、患者や家族とのコミュ ニケーションを多くもち、患者をとりまく環 境を知り、より個別的に指導することが大切 であると痛感させられた。指導をくり返し行

\section{表 1 アンケート結果}

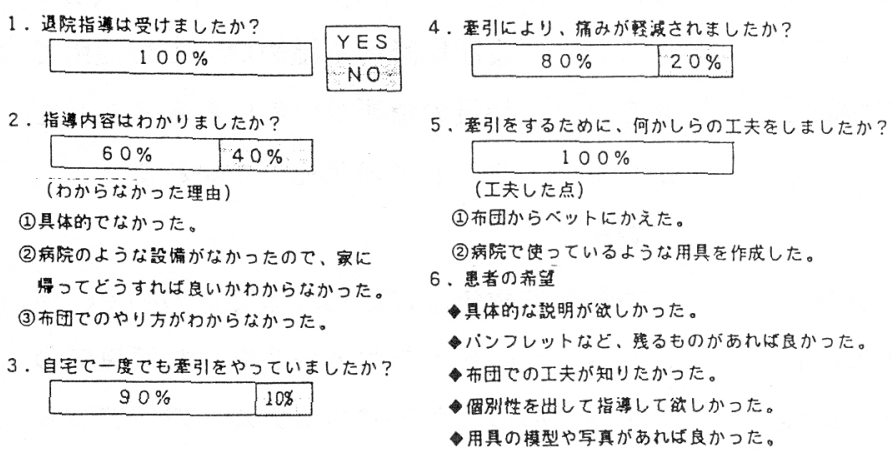

\section{図 1 毫引の実際}

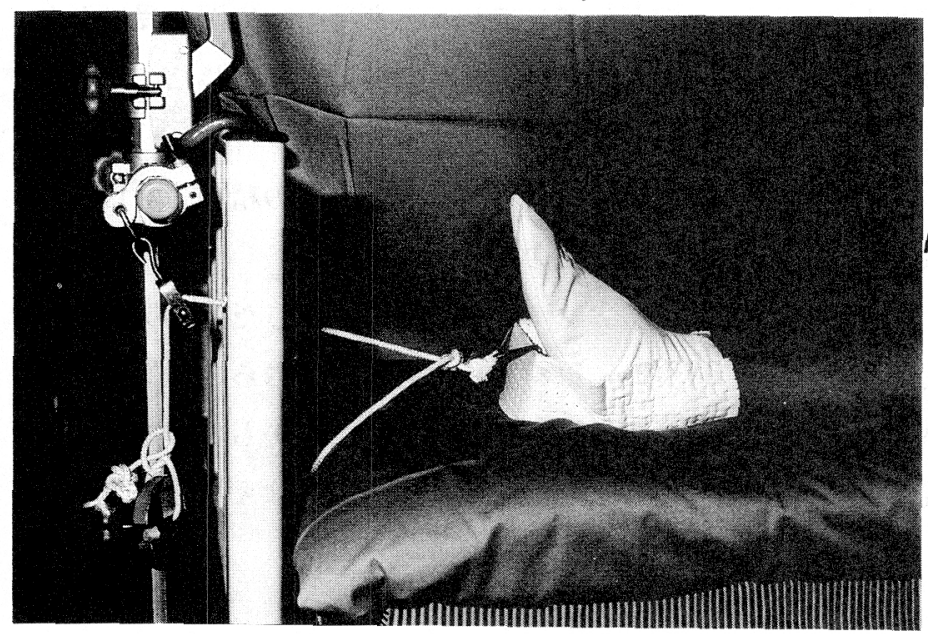

なう事は、訴えの少ない患者のいだいている 䈝問を引き出すことにもなり、その效果は高 くなると思われる。口頭のみの指導だけでな く、パンフレットを用い、視覚に訴えたこと は、患者の理解を集め、また家族の協力も得 ることができ有效であった。

〔おわりに]

患者の真担を少なくするために、外来指導 を行ない、入院しなくてもいい上うな体制づ くりとその後の継続的なフォローを、今後の 課題としたい。

\section{参考文献}

1）池田豠夫他：骨盤，股関節，図説臨㦿 整形外科講座，メジカルピュ一社

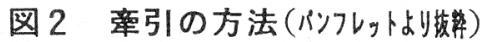

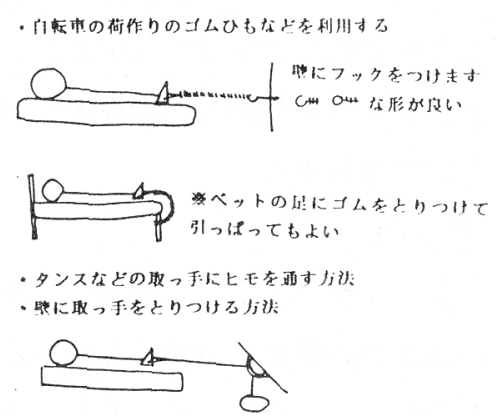

・离さを利用した方将
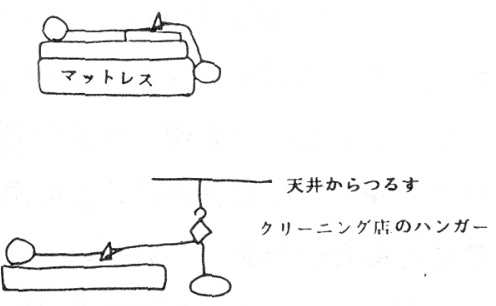

・箱などを利用した力き

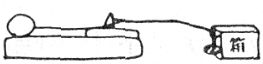


1B02 ストーマケアに対する看護婦用ケア・マニュアル 及び患者用パンフレットを作成して

○成島泰子 小林操子 諸沢洋子

須賀美由紀 小池久美子 他外科病棟スタッフー同

\section{【はじめに】}

大腸癌が増加傾向にあり、それに伴いスト 一マ造設患者も増えてきている。

当病院に於ては、32名のストーマ造設患者 が通院中で、平成 2 年より患者会を年 2 回と 平成 3 年より月 2 回のストーマ外来を開始し ている。患者会を設けてから多くの看護婦が ケアに対する興味を示すようになったが、ケ アの方法はまちまちであり、問題のある場合 にはその都度対処し、継続的なケアにつなが っていなかった。今回、ケアの統一ををはかる ことを目的にヶアマニュアルと、患者用のパ ンフレットを作製しその意義について検討し たので報告する。

\section{【方法】}

まずケアマニュアルについては、カンファ レンスの時間に、日常行っているケアの内容 を話し合い、参考資料をもとに検討した。装 具装着、保護剤使用の練習には紙粘土で作っ たストーマを厚紙に貼りつけ実際に行なっ た。一方、患者用パンフレットの作製につい ては、文字だけの説明では読む気が失せ、イ ラストを多くした方が良いとの患者側からの 意見を参考に作製してみた。

実際にあたっては造設術 7 日前に主治医よ り患者に手術の説明が行われたあと、術前患 者と話し合う時間を設け精神的援助を行な い、3日後にストーマサイトマーキング（表 I 参照）、パッチテストを実際に主治医と実 施。装着の種類を説明し、サイトマーキング の場所に24時間パウチを装着した。
(総合病院取手協同病院看護科)

\section{【結果】}

ケア末経験の者は強く関心を示し、ケア経 験のある者には、復習、確認の機会となっ た。さらに患者からは、術後10日目に、「早 くやり方を覚えなくちゃ」と、自立への言葉 を聞くことが出来た。

一方、患者用パンフレットについては、ケ アの手順、パウチの下方の止め方（表 II 参 照) については、イラストを主体とした説明 書きとしたために「これなら分りやすい」と 好評を得た。「ストーマをもちながら入浴で きること、波膚保護剤を温めなくても使用で きること、装具の種類がいろいろあることを 初めて知った。」との意見もきかれた。

\section{【考察】}

多忙な看護処置に追われる毎日の中で、患 者の二ードに沿ったケアがともすれば見失わ れがちである。ケアマニュアル、パンフレッ トを生かし、ストーマ造設患者の自立への一 歩につながれば良いと考える。このために退 院前にパンフレットを用いて質問を受けなが ら説明をすることが必要だと感じた。

\section{【おわりに】}

ストーマを受容する患者の精神的な負担は 大きいものと思われる。

ケアマニュアルを参考にした術前ケアで、 良い結果を得られたので、さらにパンフレッ トを用いた退院指導と、今後も少しでも患者 のニードに沿ったケアが行なえる様に改善し て行きたいと思う。 
ストーマの位置決め

術後の日常生活に支障をきたさない部位で、最も局所管理しやすいストーマ増設部位を決め る。患者が納得した上で、医師参加のもとに次の手順で実施する。

(1)自己管理のため、患者に主体性を持ってもらう

(2)臥位で腹部の最も隆起しているところにマジックで仮の点を打つ（複数も可）

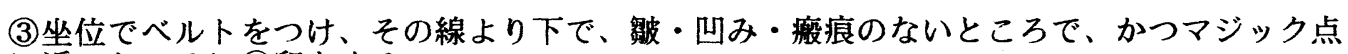
に近いところに○印をする

(4)そこにマーキングディスクを仮に置き、正座して前後屈やねじりの動作で、プレートが鼠 径部・腸骨棱・肋骨弓に引っ掛かったり、はがれたりしないことを確認する。

(5)患者自身が最適場所であることを確認し、プレートの中心に点状の入れ墨をする。

(6)開腹所見によっては目印部位に必ずしも造設されないことも説明する。

表 I ．（ケアマニュアルの一部より）

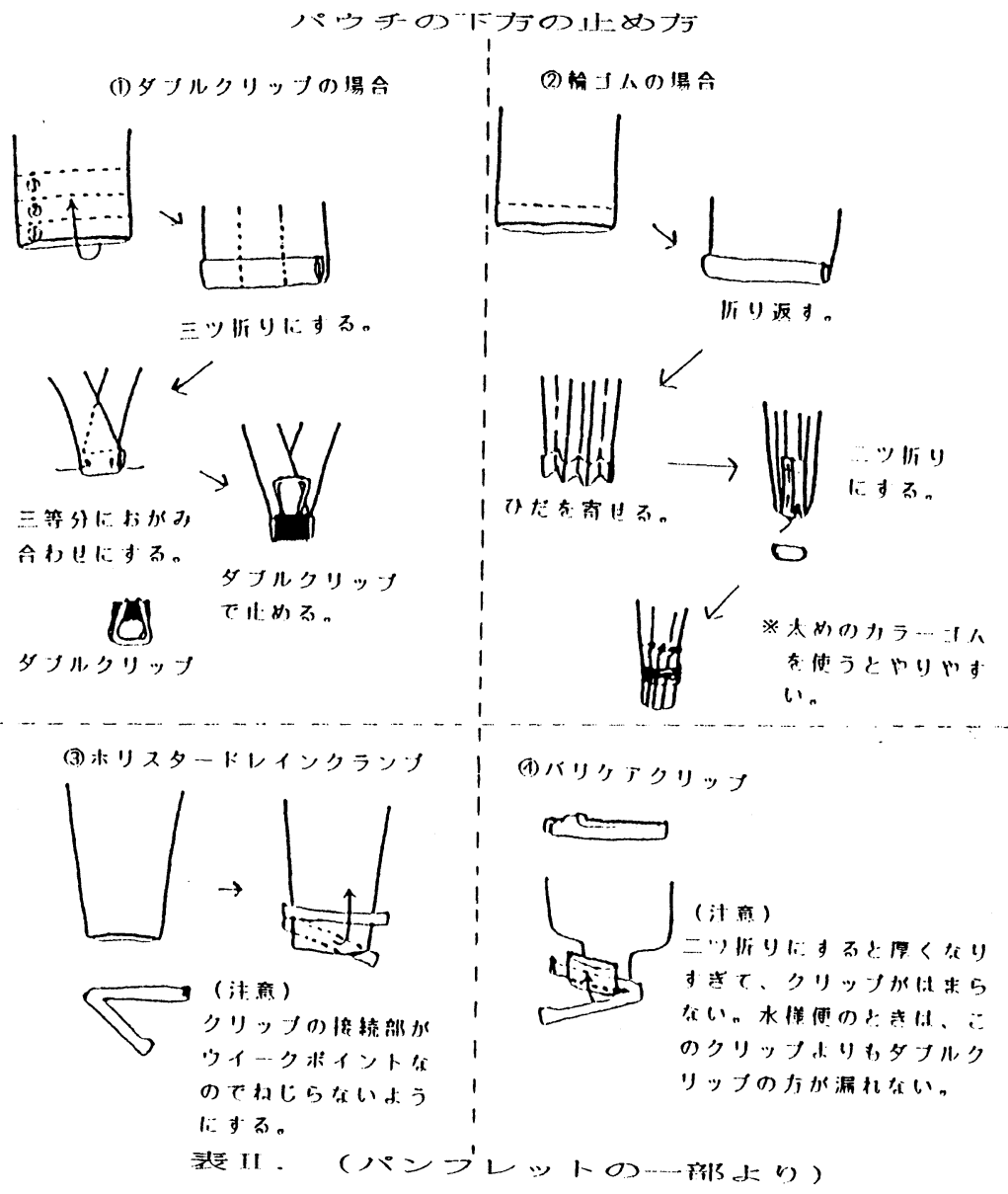


1B03 慢性閉塞性肺疾患患者の退院後の自己管理指導

高城晴美, 佐藤美佐江, 桜井佐和子

( 総合病院土浦協同病院内科病棟)

\section{I 、はじめに}

当院呼吸器内科病棟に抢いて, 慢性閉塞 性肺疾患（以下ＣＯＰ～とする）の急性增悪 により，入退院をくり返す患者は少なくない。 従って C O P D の患者管理は急性増悪予防の ための管理といっても過言でない。今回 C O P D で初めて入院した患者について, 急性増 覀予防のために自己管理に向けて, 評価表を 作成し, 退院後の日常生活の過し方の指導を 行なったので報告する。

\section{II . 事例紹介}

1. 患者 -65 才男性, 診断名 - 慢性肺気腫 - 家族構成・長男之二人暮し, 職業・農業, 喫煙歴・20〜63才まで 1 日 20 本〜 40 本

2. 既往歴・平成 3 年 8 月から糖尿病の為 薬物治療中。

3. 現病歴 - 平成 3 年 11 月 27 日上気道感染 を抢乙し呼吸困難となり当院内科へ入院とな った。

III。入院中の経過

11 月 27 日, 血液ガスの結果, 酸素 $0.5 \ell$ 経鼻カニューラで開始した。11月29日, 血液 ガスの結果,人工呼吸器による呼吸管理を開 始した。人工呼吸器装着時より不穏状態出現 し, 血圧下降も出現した。鎮静剂, 昇圧剂の 持続投与が開始された。12月4日鎮静剂中止， 12 月 5 日から人工呼吸器の設定モードを変更 しウイニング開始した。12月7日には昇圧剤 を中止, 気管チューブが抜管され人工呼吸器 より離脱した。離脱後は, 血液ガスの值を見 ながら酸素投与量を減らしていき 12 月 17 日に
酸素投与中止。その後呼吸苦出現せず 12 月 24 日, 血液ガスの結果退院となった。

\section{$\mathrm{IV}$ 。看護の展開}

人工呼吸器装着時 退院時まで

1. 問題点

1) 人工呼吸器装着したため不穏状態が出 現。

2 ）四肢の活動制限による筋力低下

3 ）長男と二人暮し

2. 看護目標

1 ）不穏状態が消失する。

2 ) 人工呼吸器から早期離脱ができる。

3） A L が拡大できる。

4 ）日常生活の自己管理ができる。

3. 看護の実際

1) の目標に対して, 30 分毎の観察を行な い人工呼吸器装着の必要性について説明し, 不安の軽減につとめた。読唇法や筆談法によ り,意志の疎通を図った。鎮静剂の持続投与 の管理を行なった。2）の目標に対して, 腹 式呼吸の必要性を説明し, 砂のう・ストロー を用いて実施した。3) の目標に対して ADL の拡大に向け,下肢の筋力増強のための運動 療法を行なった。4) の目標に対して自己評 価を作成し, 患者自身に記入させた。退院に 向け，日常生活の過し方のパンフレットを作 成し指導をした。

4. 結果 1) の実際に対して, 人工呼 吸器装着の必要性を説明し, 読唇法や筆談法 によりコミュニケーションを図ったてとで, 徐々に不穏状態は消失してきた。2）の実際 
に対して腹式呼吸の必要性を理解でき積極 的に練習を行なっていた。乙の結果 12 月 7 日 には抜管でき人工呼吸器装置より9日目で離 脱することができた。抜管後すストロー，砂 のうを用いて腹式呼吸を続け呼吸筋の筋力増 強につとめた。3）の実際に対し抜管終了 日より AD L 訓練を開始した。ベット上の坐 位訓練, 立位。歩行訓練へとパルスオキシメ ーターにて酸素飽和度を測定しながら行なっ た。酸素飽和度の值は 95 97\%を示し順調に 下肢の運動療法が進み ADL が拡大された。

4 ) の実際に対し自己評価表の項目にそ って1日1回朝の検温時に看護婦といっしょに 記入していった。15の項目に対しきちんと記 入されていった。食事, 排泄, 清潔, 薬, 運 動療法, 呼吸訓練。呼吸苦出現の対処法につ いてパンフレットを用いて説明した結果, 熱 心に聞いており理解できない所は質問をして きた。何度かくり返し説明指導した結果。患 者の反応からほぼ理解されたと確認した。

\section{$\mathrm{V}$ 。考察}

人工呼吸器装着後の不穏状態出現に対して は頻回の観察, 人工呼吸器装着の必要性を説 明し。コミュニケーションの充実を計るてと により患者に安心感を与え消失できたと考え られる。人工呼吸器からの早期離脱について は, 早期から呼吸訓練を開始したてと, 患者 自身の回復意欲が強く, 医療者側に協力的で あったことが。良い結果につながったと思わ れる。自己評価表を作成したことは毎日患者 自身が。自己の体調をチェックすることによ り, 自己の状態把握が出来るとともに, 疾患 の理解が深まったと考えられる。乙れは退院 後の日常生活の指導に打いても, 自己管理の 意識づけができ, 効果的であったと思う。 退院後毎月 1 回の外来受診日に自己評価表を
持参してくることからも，自己管理に十分注 意している様子がうかがえた。

VI。おわりに

患者は外来受診した際に血液ガスを測定し た結果 2 月には $\mathrm{PC} \mathrm{O}_{2} 40.1 \%, \mathrm{PO}_{2} 61 \%$,5月 には $\mathrm{PC}_{2} 46.7 \%, \mathrm{PO}_{2} 62 \%$ と安定した状態で 日常生活を過している。乙の症例をと打して C O P D の患者の急性増悪予防には生活指導 と自己管理指導が大切であることを学んだ。 今後屯急性増悪予防に向けての指導を充実さ せてゆきたい。

\section{参考文献}

堀江孝至, 木下由美子, 在宅酸素療法ガ イドブック，医学書院，1990

米山朝子, 若菜キヨ, 山岸春江, 呼吸器 疾患患者の看護, 日本看護協会出版会, 1988

\section{自己表価 表}

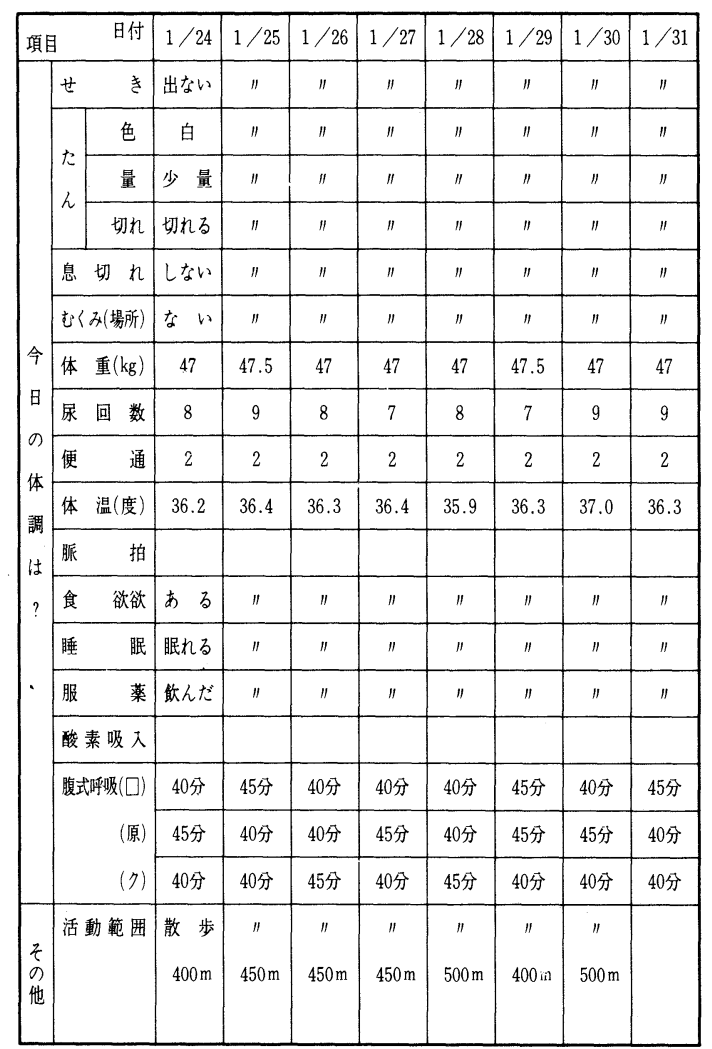


はじめに

当院に打いて 1991年12月31日現在, 血液透 析を受けている患者は 191 名（男 113 名，女 78 名) であり, 透析歴 5 年以上の長期透析は 98 名で全体の $51 \%$ を占めていた。透析患者の 日常生活はその治療に関わる拘束時間と種々 の制約などで健常者に比べ様々なハンディを 負っている。乙のような条件の中で, 日常ど の様な制約に関わっているか，医療スタッフ との信頼関係は成り立っているかという点に ついて今後の生活指導の参考にするため調查 を試み, 当院に於ける透析患者の実態と併せ て報告する。

\section{I 。対象と方法}

透析歴 5 年以上の長期透析患者 98 名を対象 とした。社会復帰の状況, 合併症, 生きる支 え, 一日の嫁働時間, 趣味娛楽の面からアン ケート方式により調查を行った。

\section{II 。当院に拈ける透析患者の実態}

図 1 は年齢別透析患者数である。働き盛り の 40 代から 60 代が最あ多い。

図 2 は透析年数別患者数をみたものである。 最長透析症例は 51 歳男性で 19 年 10 ケ月であっ た。10年以上の透析歴を持つ患者数は 40 名で 全体の $21 \%$ あっった。

III。結果

図 3 は透析歷 5 年以上の患者の社会復帰状 況をみたものである。主婦を含めた $69 \%$ の患 者が就労していた。無職者の理由としては高 齢であるとと, 定年退職が主であり, 職場が ない，働く意欲がないと答えた患者はわずか
4 名であった。就労者の一日の稼働時間を透 析日, 非透析日別にみると, 多い人で非透析 日は 12 時間, 透析日は 7.5 時間であった。主 婦では非透析日 10 時間, 透析日は 3 時間であ った。透析日の食事の準備は前日か当日の来 院前に行うと答えた患者が多かった。これは 透析療法による疲労が大きいためと思われた。

合併症では関節痛が $64 \%$ あっとも多く， 次いで掻痒感, 不眠などであったが, 仕事中 に痛みやかゆみを自覚している患者は少なか った。

趣味・娛楽の面としては就労者の平日はテ レビと答えた患者が半数を占め, 他に読書, 仕事の書類整理があげられた。休日はテレビ, スポーッ, 買物, ドライブ, 写真撮影など多 彩な過ごし方をしていた。主婦の場合は平日 - 休日と屯家事一般, 家族との外出が主で, 他に草木の手入れなどがあげられた。

図 5，6は心の支えになっているてとにつ いて調查したものである。49\%が家族と答え ておう, 既婚者は妻や夫の愛情, 子の成長を あげ, 高歯者は優しくしてくれる孫の成長が 楽しみだと答えていた。独身者では自分自身 と答え，前向きに生きる姿勢が感じられた。

医療従事者之の信頼関係はできていると答 えた患者は $73 \%$ と高かった。職場の人と話を するより医療スタッフと話をする方がずっと 楽しいと答えた患者もいた。また，長期にわ たる治療であるてとから気心あ知れて生活上 の悩みあ相談できる看護婦あいると答えた患 者もいた。 


\section{IV。考察}

当院の透析患者の社会復帰状況は, 就労率 が約 $70 \%$ と比較的高率であった。就労者のほ とんどは夜間透析であり, 帰宅後あ仕事など を行っており, 稼働時間は健常者とかわりな いようであった。主婦の稼働内容は家事やテ レビなよ゙で特記すべき事はなかったが，家の 中の雑用であ身体を動かし自分なりの生き方 ができれば社会復帰につながると思われた。

家族と同居している独身者の場合, 社会資 源に頼ることによって就労意欲が減退してい る患者あみられたが, 私たちはどの様な形で あれ社会に還元するという意識を向上させる ベく働きかけをしていかねばならないと考え る。現実的には透析患者などの身体障害者の 雇用条件は厳しいため, 希望するような就労 は容易でないことが多いが, 例えば高齢者や 他の障害者の病院への送迎などのボランティ ア活動を行うことによって，定職を持たずと む十分社会に還元できると考え，患者個人に 合わせた指導を進めている。

生涯続けて行かねばならない透析療法にお いて, 家族は何よりの生きる支えであると思 われた。医療スタッフも心の支えとして高い 数值を示したが，乙れは私たちが行う看護の 姿勢が評価され，また受持ち制であることか ら検查データの説明や日常生活の指導などを 繰り返し行っていく中で自然に信頼関係が完 成されたものと考えている。臼井は「患者は 家族からの医療スタッフからの絶えざる肯定 的ストロークによって生きるのに必要なエネ ルギーを持つのである。」と述べている。と あすれば毎日同じ事の繰り返しでマンネリ化 しがちな透析看護の中で, 常に患者により良 いストロークが与えられるような心の余裕が 私たち医療スタッフに望まれると考えられた。

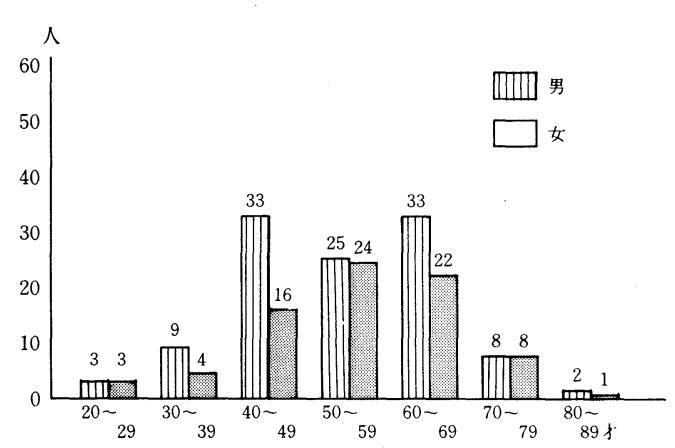

図 1 . 当院における年令别透析息者数

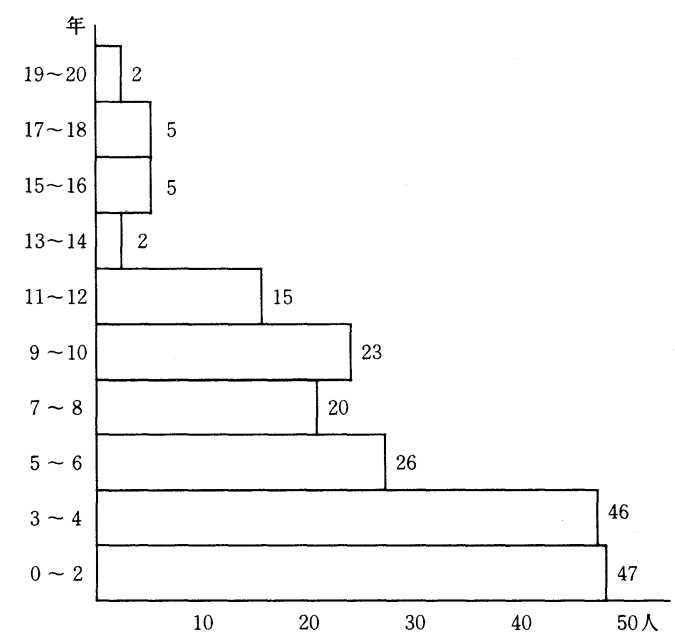

图2 当院における年数别息荋数

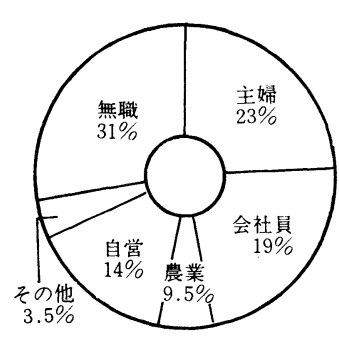

图3. 当完における社会得州状況

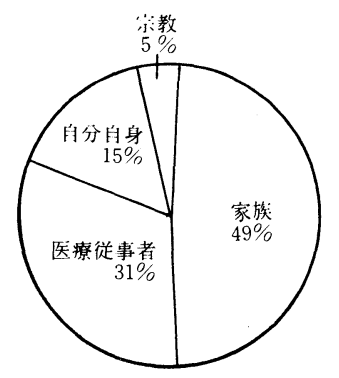

图4.生旻えとなっていること

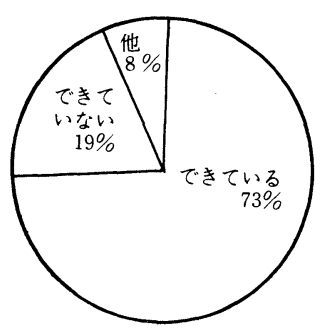

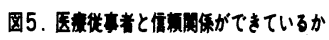


1B05

精神科病棟におけるバイキング給食の試み

一環境の工夫から食行動を考える一

上都賀総合病院 精神科開放病棟

○小林庙恵半田登美恵大島敏子

池沢充行永田美枝

はじめに

初回は席が選べず職員に決めてもらう患

精神神経科病棟において患者の食行動をみ

ていると䇟合った者、向かい合った者同志の

会話がほとんどなく、黙々と食物をロに運び、

食べ䊏わるとまっすぐ自分の部屋に戻ってし

まうという孤独な行動となっている。

そこで、私達は食事を味わい楽しむ環境作

りを考え、バイキング給食を陚みた。

その結果、患者の食行動に変化をみること ができたのでここに報告する。

I. 研究目的

1.バイキング給食に自ら主体的に参加でき、

食品の種類と量、食器を選ぶ事ができる。

2. 対人交流や会話をもつことにより、楽し

い食事ができる。

II. 研究方法

1. 研究期間 1991年 7 月 1991年12月

2. 対 象入院患者全員 (25 30名)

3. 方 法

1)バイキング給食を月 1 回昼食時に実施し た。

2)給食部門との話合いで実施日を決定。

話合いの中から患者の希望メニューを取 り入れた。

3)場所はディルームとし、テーブルの配置、

花、音楽等で食事環境作りを行った。

III . 対策と結果

1 。席を自由として、人的環境の選択が患者 とできるようにした。

普段、1テーブル4名のところ6〜7名 とし職員が同席することで会話が増えた。 者が $5 \sim 6$ 名いた。2回目からは自ら席を 決めたり、気の合った患者同志や同室者と 話合いながら同席する様子がみられた。

2. 食事の雾囲気作りとして、テーブルクロ スを変え、B G M を流し、季節の花を飾っ た。又、食後、コーヒー、紅茶を出すこと でティータイムを設けた。

少数の患者からではあるが、「テーブル クロスを変えるんですか」「この花は何と いう花ですか」「音楽を聴きながら紅茶を 飲んでいると、喫茶店にいるみたい」等の 言葉が聞かれた。いつもの食事時間よりも 会話が多くなり、ティータイムを設ける事 で、今まで10分程度で終わっていた食事が 40 分程度に延長された。3回目頃よりバイ キング給食の環境作りをしていると 4 〜 名の患者が、「テーブルを運びますか」

「どこに置きます」「拭きますよ」と自ら 手伝ってくれるようになった。

3. 料理の配置テーブル及び料理、食器の並 ベ方の工夫をした。

料理を配置するテーブルをディルームの 端に置いたため、離れた埸所にいた患者は 最後の頃の盛りつけとなり、膳をもって席 につくのが大変だったりおかわりもしづら かった。心理的に食事のとりやすい中央に 配置した事でおかわりもしやすくなった。

食器はテーブルの 1 ケ所に配置したとこ ろ、盛りつける段階で先に進まず列ができ てしまったり、盛りつけの途中で器の補充 
がみられることがあり混乱した。2回目よ り、テーブルの 3 ヶ所に配置することでそ の場から料理を盛りつけられ混乱はなくな った。

料理は、配色に気を配り、主食、副食を バランスよく並べ、食欲をそそるように配 置した。

8 割の患者は料理に合わせ食器を選ぶこ とができていた。

IV. 考察

(1)長期入院患者においては、環境の変化に対 応できず戸感いや不安がみられた。「好きな 所に座って下さい」と声をかけても自分で席 を決められずにいた患者には、空席を知らせ たり、同席者を瀷んであげることで安心した。 2 回目からはそれらの事は少しづつ解消され ている。日頃の食行動で黙々と食べている対 人交流の持てない患者に対しては同じテーブ ルで職員が関与することによって改善への対 策をみつける糸口となった。

(2)バイキング給食を行うにあたり、テーブル クロス、花、音楽等環境の工夫を行ったが、 回復期の患者が変化に気づき、食事中話題を 提供してくれ、他の患者によい刺激を与えて くれた。

(3)バイキングのメニューの意見や希望を聞い てみると、「品数があるから好きなものが選 ベて良い」「食べられるだけ取れるので良い」 と聞くことができ、满足感を与えることがで きた。ディルームで食事ができるようになっ たり、食欲不振を訴え、1/3程度しか食べ ていなかった患者が自ら盛りつけ食べること ができたことは、バイキング給食という聞き なれぬ言葉に関心を持った事、食事環境の変 化により行動が変化した事が考えられる。

患者の反応や行勤の変化が起りにくいよう
に感じられたが、入院疾患構成の50\%が、う つ、抑うつ状態で占められている事があげら れるかもしれない。

食事場面の変化や献立を中心に関わり介入 することで対人関係や協調性、食事に対する こだわりや揕食障害の改善など様々な分野に 渡り学ぶことができたので治療的、看護的関 わりに役立て効果が得られたものと考える。

バイキング給食は、マンネリ化した食事行 動のあり方に、ひとつの新しい刺激を与える ことができたと考える。

V.おわりに

今回の研究で、バイキング形式の昼食は精 神疾患患者にとって、食事行動の変化を起こ させる機会となった。今後は、バィキング給 食以外のことについてもエ夫し、多角的に患 者に関わっていきたい。

参考文献

- 松本邦裕 西園昌久: 精神分裂病、うつ病 者、神経症者の食事行動研究 季刊精神㙩 法 9 (4) : 381 393，1983 
はじめに

入院生活に扔いて, 患者はベットを中心に あらゆる日常生活をくり広げている事が大半 である。しかも, 患者が老年期であり,また 運動機能障害の回復期である時, ベット上で の生活は, 身体的・精神的に回復のスピード を遅らせ生活意欲の減退につながる恐れがあ る。

今回我々は, リハビリテーションは病棟で の日常生活動作そのものの中でたえまなく行 われるあのであり, 治療の場は生活の場であ るという考えのあとに，人間が生活するうえ の基本条件である食事環境に着目した。食事 環境を家庭に近づける事で, 個性・感情が表 出され, 日常生活動作の拡大・生活意欲の高 揚につながる第一歩と考え, 食事環境の改善 を試み, 効果が得られたので報告する。

\section{I 。研究目的}

1. 入院生活, 及びリハビリテーションに対 する意欲を引き出す。

2. 人間交流の発展・精神的安定をはかる。

\section{II 。研究方法}

1. 期間：平成 4 年 3 月～継続中

2. アンケート調查

3. 食事会対象者：リハビリ施行中の患者を 中心に, 自由参加。

II。実施及び結果

食事環境に関するアンケート調查（図 1) から, 病室以外で食事をとってみたいという 患者が約半数あり, 早速食事会を開始するて とにした。

\section{図 1 食事環境に関するアンケート}

（質1）ベット上で食事をとる事に抵抗を感じますか。

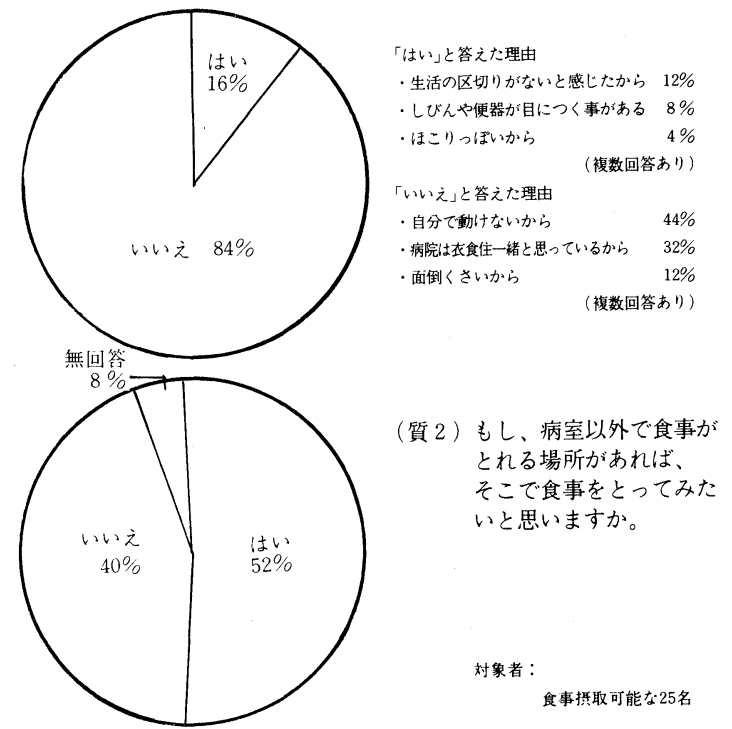

部屋は, カンファレンス室を開放し, 視覚 聴覚的な刺激を与える為に以下の工夫をした。

1. 草花を飾る。

2. 看櫵婦が描いた季節感を思わせるイラス 卜を飾る。

3. テーブルクロスを用いる。

4. 患者の搘好飞合う音楽を静かに流す。 食事会の実施・介助飞あたっては, 参加目 的を十分説明し, 食前の排泄・手洗い, 食後 の内服・歯みがき等の習慣づけを行った。ま た，参加者の中には，「食べてぼしをして遅 いから恥しい」と周囲を気にし，食事会が $\mathrm{A}$ D L 拡大の場であるという意識があてず，抵 抗をみせる患者もいた。その為, 同じょうに 障害をむつ患者であり羞恥心にとらわれない 様に励し, 残された機能への動きがけに留意 する一方, 患者自身の意志で参加するまで待 


\begin{tabular}{|c|c|c|c|c|}
\hline \multicolumn{2}{|c|}{ 事例・年柃 } & A $\cdot 78$ 藏 & B. 80 歲 & $\mathrm{C} \cdot 76$ 歳 \\
\hline \multicolumn{2}{|c|}{ 性＼cjkstart別 } & 우 & 우 & q \\
\hline \multicolumn{2}{|c|}{ 病名·症状 } & 脳出 血 & $\begin{array}{l}\text { 小脳出血 } \\
\text { 右半身麻禈 }\end{array}$ & 䑈 梗塞 \\
\hline \multirow{2}{*}{$\begin{array}{ll}\text { 移 } & \text { 動 } \\
\text { 姿 } & \text { 勢 } \\
\text { 保 } & \text { 持 }\end{array}$} & 前 & $\begin{array}{l}\cdot \text { ほとんどべット上 } \\
\text {-介助で坐位 } \\
\text { ·介助車イス移動 }\end{array}$ & $\begin{array}{l}\text { ・ベッド上臥床 } \\
\text { ギャッジアップ坐位 } \\
\text { 保持 }\end{array}$ & $\begin{array}{l}\text { ・ヘット上卧床 } \\
\text { ・介助車イス移動 }\end{array}$ \\
\hline & 後 & $\begin{array}{l}\cdot \text { 自力坐位 } \\
\text { ·自力車イス移動 }\end{array}$ & $\begin{array}{l}\cdot \text { 莝位保持可 } \\
\cdot \text { - 一部行動車イス移動 } \\
\cdot \text { 日中起坐位でいる事 } \\
\text { が多い }\end{array}$ & - 杖步行 \\
\hline \multirow{2}{*}{$\begin{array}{lr}\text { 周曲との } \\
\text { かかわり } \\
\text { 表 } & \text { 情 } \\
\text { 発 } & \text { 語 }\end{array}$} & 前 & $\begin{array}{l}\text { ·家族を交えての会話 } \\
\text { ·閒く側 }\end{array}$ & ·会話のくい違い多い & ·自発的な発語少ない \\
\hline & 後 & $\begin{array}{l}\text { ·話しかけることで会 } \\
\text { 話に加わる } \\
\text { (家族なしでも) } \\
\text { ・笑顔がみられる } \\
\end{array}$ & $\begin{array}{l}\cdot \text { ·会話ほほ成立 } \\
\text { ·表情豊になる }\end{array}$ & $\begin{array}{l}\text { ·他患者と積極的会話 } \\
\text { おり }\end{array}$ \\
\hline \multirow{2}{*}{ 排泄状況 } & 前 & $\begin{array}{l}\text { ・オムツ使用 } \\
\text { 車イストイレ } \\
\text { ·康意訴えあり } \\
\end{array}$ & $\begin{array}{l}\cdot \text { 尿意なし } \\
\text { ・オムツ使用 } \\
\text { ・排泄後の訴えなし } \\
\end{array}$ & $\begin{array}{l}\text { ·オムツ使用 } \\
\text { ·便器介助 }\end{array}$ \\
\hline & 後 & $\begin{array}{l}\text { ・オムツ使用しないで } \\
\text { 車イストイレ }\end{array}$ & $\begin{array}{l}\text { 尿意なし } \\
\text { ・オムツ使用 } \\
\text { ·排尿後の訴えあり }\end{array}$ & $\begin{array}{l}\text { ·介助車イストイレ } \\
\text { ·杖步行でトイレに行 } \\
\text { く }\end{array}$ \\
\hline \multirow{2}{*}{ 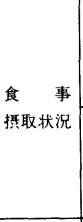 } & 前 & $\begin{array}{l}\text { ·自力搷取 } \\
\text { スプーン使用 } \\
\text { 監視が必要 } \\
\text { ·食べこほしあり }\end{array}$ & $\begin{array}{l}\text { ·自力搷取 } \\
\text { フォーク・スプーン } \\
\text { 使用 } \\
\text { ·食べこはしあり } \\
\end{array}$ & $\begin{array}{l}\text { ·自力撕取しようやく } \\
\text { スプーン・フォーク } \\
\text { 使用 }\end{array}$ \\
\hline & 後 & $\begin{array}{l}\text { ·自力買取 } \\
\text { スプーン使用 } \\
\text { ·食べこはし少なくな } \\
\text { る } \\
\end{array}$ & $\begin{array}{l}\text { ·自力撜取 } \\
\text { フォーク・スプーン } \\
\text { 使用 } \\
\text { ·食ベこはし少なくなる }\end{array}$ & $\begin{array}{l}\text { ·自力掑取 } \\
\text { 箬使用 }\end{array}$ \\
\hline \multirow{2}{*}{\begin{tabular}{ll|} 
リハピリ \\
意 欲
\end{tabular}} & 前 & $\begin{array}{l}\text { · A D L搪大に对し勇 } \\
\text { 気みられず }\end{array}$ & ·吿気力 & - 依存的 \\
\hline & 後 & $\begin{array}{l}\text { ・アプローチに对し樍 } \\
\text { 要的に步行器步行な } \\
\text { ど試みる }\end{array}$ & $\begin{array}{l}\text { ・自力で起きようと意 } \\
\text { 欲みられる }\end{array}$ & ・意欲みられる \\
\hline
\end{tabular}

ち，負担をかけない様にした。また。時々食 事中に沈黙が長く続く事もあり, 看護婦がム ードメーカー的役割りをになった。その結果 中でもADL拡大につながった 3 事例を（表 1) に示す。

\section{IV。考察}

事例 $A \sim C$ は, 食事会に参加する事で A D L 拡大につながると同時に, 看護婦や他の患 者とのコミュニケーションの場となり, 精神 的安らぎを得ることが出来た。この結果を得 られた要因として，(1) 音楽や部屋のイメー ジなどで，視・聴覚的刺激を与えたこと，(2) 同じように障害をもつ患者を目前にし，自分 だけではないという勇気がもてたとと，(3) 看讙婦は患者の意欲を引き出す為に, 患者自 身が行動に移すことを待ち，見守る姿勢を大 切にしたとと, (4) 食事会の場で, 看護婦が
ムードメーカー役をになったてとなどが考え られる。

今回の食事会を実施した事は, 入院生活の 場から一部を家庭環境に近づけ，更に生きる 意欲を生み出す場面を提供したといえる。

老化を伴う身体・知的機能の低下は, 老い たら誰むが体験する事である。また，慢性疾 患をかかえ機能障害をむつ老人が生きる意欲 を見いだすでとができる様に，看護・医療チ 一ムが共に患者に対して，保護と援且:の手を さしのべる事はいうまでもない。

詩人ゲーテは，「人は誰しも老いられるが しかし，老いに耐えることは難しい」と言つ ている。現在の高齢化・核家族社会の中で, 耐えている老人に対して私たちはどの様にサ ポートしていけばよいのかを考える時，私た ち自身がいずれ老いるという事を自覚して援 助する事が必要なのではないだろうか。

\section{打わりに}

今回, 家庭内環境に近づけた雾囲気での食 事会を開始し，それぞれの目的の一部を達す る事ができた。今後は, 更に生活活性化を図 る為にも。季節感を取り入れた行事などを考 え，患者の充実した入院生活が送れるよう援 助を続けたい。

\section{引用文献・参考文献}

1) 日野原重明：老人患者のクオリティ・オ ブ・ライフ, 中央法規, 1988 .

2 ）三宅貴夫, 五島シズ：老いて病む人への 看護, 医学書院。1986.

3 ）三宅貴夫：障害をむつ老人の心とその援 助, 看護, 44(2); 22-29, 1992.

4 ）福井国彦・宮森孝史：老年者のQOL プ ログラム, 医歯薬出版株式会社, 1990. 


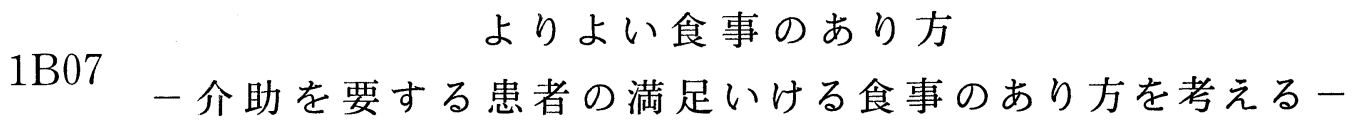

○川和子, 稲葉満理子, 山中美江子

(総合病院土浦協同病院整形外科病棟)

I 。はじめに

当院整形外科患者の中において, 身体の機 能的条件で, 食事の介助が必要となる場合が 多い。しかし。その食事介助は, 看護婦と患 者にとって満足のいけるあのだろうか。検查 や処置の忙しさに追われて，患者のニードに てたえた介助ができるのだろうか。

そこで今回, “食事”についてのアンケー トによって, 患者の意見を把握し, 看護婦の 意見とのギャップを明確にしながら，本来の よりよい食事のあり方について振り返り。改 善策を検討したので，報告する。

II 。アンケート調查

1. 目的

食事について, 患者と看護婦にアンケート を行ない，両者の意見より問題点を明確にし 今後の援助に役立てる。

2. 期間

平成 4 年 1 月 3 日 2 月 20 日

3. 対象

食事介助をうけたととがある患者 20 名 看護婦（助手 2 名含む） 23 名

\section{4. 調查内容}

アンケート内容（表 $1 ， 2$ ）

簡単に答えられるよう選択を多くし，“満 足”については，具体的に意見を述べてもら う形成とした。

\section{III。結果, 考察}

回収率 患者 $100 \%$ 看護婦 $100 \%$

患者プロフィール（表3）

アンケート結果（表 4 ）
表 4 より, 看護婦は, 理想とかりはなれた 現状からと考えるが，「満足していない」の 解答がほとんどである。乙れは。気持ちの中 では，むっとむよいと思う介助法を，それぞ れが求めていることが十分伝わる。

一方, 患者は, 食事介助に満足している解 答が多い。「姿が忙しそう」，「申訳けない 気持ちでいる」等, 看護婦の印象を述べてお り，また表 3 より，50代以上が過半数をしめ 年齢的にも遠慮しての解答と考える。

両者解答は相違したが, 互いの意見をまと め, 以下について改善策を検討した。

(1)患者に遠慮がある

(2)業務内容による忙しさ

(3)食事内容に問題がある

(1)について, 自己摂取への工夫に取組んだ。 まず。自助具の活用である。リハビリテーシ ョンと関わりをあち，患者に適したものを作 成し, 実際使用したところ, 手指のきかない 患者が，自己摂取可能となった。また。ベッ ドサイドに飲水ボトルを設置し, 顔面を少し 動かすだけで，好きな時すぐに飲水できるよ うストローの工夫を行なったとてろ，患者 からあ好評であった。

他に，臥床してあ食べやすいように，主食 を招にぎりやパンに変更したり,プリズムメ ガネや手鏡も活用を試みた。しかし、メガネ や鏡については, テーブルのセッティングの ずれや，高齢者には難しいすのがあった。

(2について, 夜勤帯の業務改善を行なった。 まず, 処置等の時間変更（例，尿測や輸液交 
換の時間等），早出・遅出等の勤務体制の変 更, また, POS 導入での申送りの短縮化に より，少し時間にゆとりがあてるようになっ た。

(3)について, 介助して気がつく, 食器やメ ニューの問題である。例えば, めん類や汁の たっぷり入ったお椀等は, 介助しにくいもの がある。患者も同意見を示しているため, 栄 養科へ提案する必要があると考える。

IV. 掞わりに

患者の基本的ニードを満たすために、いか なる援助が必要か。今回，小さな疑問点から 看護婦スタッフの協力を得て，大づかみなが らも患者の意見を聞け。忘れてしまいがちな 患者のための看護を再認識した。

今後も, 問題は多くあるが, よりよい看護 の提供に努めていきたい。

\section{<表 $1>$ \\ 食事についてのアンケート（患者） \\ (1) 性別（男・女） (2) 年齢（20代・30代 40 代 $\cdot 50$ 代 $\cdot 60$ 代 $\cdot 70$ 代)}

(3)看護婦が介助した場合についてたずね ます。

1) 一回の食事時間は, (5 分以内 $5 \sim 15$ 分 $\cdot 20$ 分以上)

2 )介助の仕方は適当ですか。

（はやい・適当・打そい）

3 ）介助で満足した食事がとれてますか。

(満足・まあまあ・満足ではない)

※満足でない方は，なぜですか。

( )

4 ）遠慮して食事してますか。

（はい・いいえ）

※はいの方は,なぜですか。

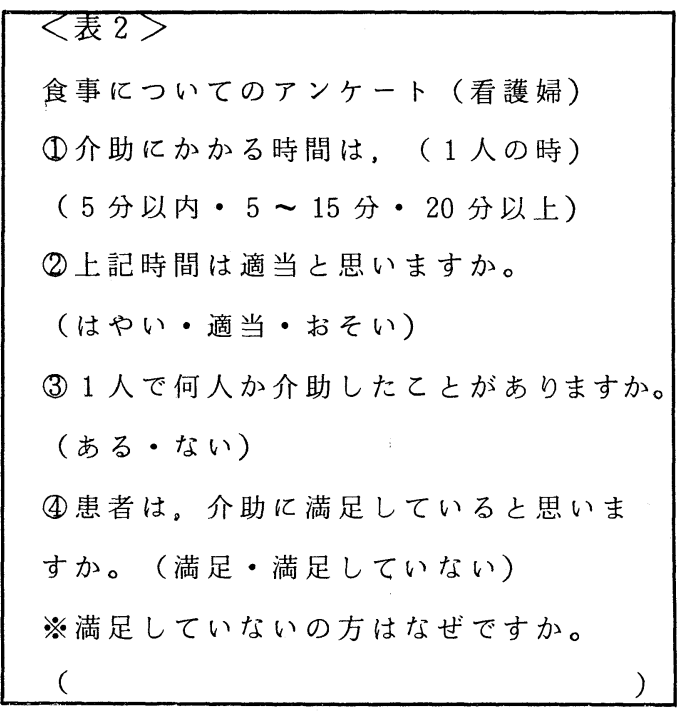

\begin{tabular}{|c|c|c|c|c|c|}
\hline \multicolumn{6}{|c|}{$\begin{array}{l}\text { 表3> } \\
\text { 患者プロフィール }\end{array}$} \\
\hline \multirow[t]{3}{*}{ (1) 性別 } & 男 & 9人 & \multicolumn{3}{|c|}{ (2) 年 齢 } \\
\hline & 女 & 11 人 & & 20 代 & 4 人 \\
\hline & 計 & 20 人 & & 30 代 & 2 人 \\
\hline \multicolumn{4}{|l|}{ (3) 疾 患 } & 40 代 & 0 人 \\
\hline \multirow{4}{*}{\multicolumn{3}{|c|}{$\begin{array}{l}\text { 脊䯣損傷・四肢麻瘴 } \\
\text { 骨折（牽引・固定等） } \\
\text { 脊椎の手術後 } \\
\text { 肢関節の手術後 }\end{array}$}} & 5 人 & 50 代 & 泩人 \\
\hline & & & 8 人 & 60 代 & $=5$ 人 \\
\hline & & & 5 人 & 70 代 & 每 4 人 \\
\hline & & & 2 人 & 計 & 20 人 \\
\hline \multicolumn{3}{|c|}{ 計 } & $20 人$ & & \\
\hline
\end{tabular}

〈表 4〉

アンケート結果（概略）

(1)時 間

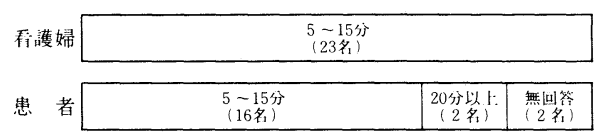

(2)满足しているか

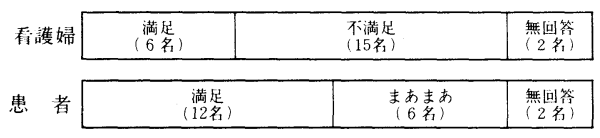

(3)遠慮はないか
患 者

\begin{tabular}{|c|c|c|}
\hline $\begin{array}{l}\text { 典多) } \\
6 \text { 多 }\end{array}$ & $\begin{array}{l}\text { 忩口 } \\
\text { (12名) }\end{array}$ & 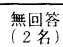 \\
\hline
\end{tabular}

(4)何人か介助したことがあるか

\begin{tabular}{|l|l|}
\hline 看護婦 & $\begin{array}{c}\text { ない, } \\
\text { ある(22名) }\end{array}$ \\
\hline
\end{tabular}


1B08

\section{手術を拒否して自己退院した患者の看護介入を振り返って}

一ロイ適応モデルに基づく看護介入に沿って検証する一

$\bigcirc$ 松本俊子, 江幡世利子

I 。はじめに

本症例は正しい病識を持たないままに手術 を拒否して自己退院した。当初, 患者家族の 問題あるいは患者医師との信頼関係の問題と 捉えていた。しかし，終始治療に非協力的な 態度をとった患者に対して看護婦の看護介入 にこそ問題はなかったのかという疑問が残っ た。そこで, ての症例の心理社会的側面に焦 点をあてロイ適応モデルに基づく看護介入に 沿って検証した。

\section{II 。患者の紹介}

76 才男性入院時主訴: 食欲不振

病名：胃癌 B ormann III $S$ 状結腸ポリープ 既往歴: S 16 年 急性虫垂炎で手術

$\mathrm{S} 38$ 年 糖尿病で食事療法

$\mathrm{S} 62$ 年 事故による脳挫傷

$\mathrm{S} 63$ 年 前立腺肥大で手術, 白内障 硬膜下血腫で手術

現病歴: H 3 年 3 月左側腹部痛が出現し近医 で胃透視を受け手術を勧められたが拒否し， 別の病院で同様に勧的られ H 3 年 4 月 2 日当 院へ手術目的（胃全摘・膵脾合併切除を予定 していた）で入院となった。

家族歴: 父は80才で脳出血, 母は36才で白血 病, 二人兄弟の弟は74才で老衰のた め亡くしている。

家族構成: 74 才の妻, 50 才代の長男夫婦, 10 才代の 2 人の孫

入院前の役割：隠居しているが世帯主

兼業農家のため農業の手伝い

趣味：野菜を作ること
（総合病院土浦協同病院外科病棟）

性格: 頑固, 思い込みが強い

入院から自己退院に至るまでの経過：入院後 連日術前検查を受け一般状態に变化はなかっ た。11病日に高血糖となりインシュリンを開 始し12病日には自己判断で食事を減らしたた め低血糖発作を起こした。翌日, 血糖コント ロールのため手術延期の説明をする。その後 治療に非協力的になり 15 病日に無断外泊, 家 族と話し合いの結果17病日に自己退院となる。

III。看護の実際

看護目標: 症状の出現がなく検查, 手術に望 むととができる。

\# 1. 胃癌に起因する食欲不振がある。

\# 2. 血糖コントロールの協力が得られない 患者行動（看護記録から抜粋）

\begin{tabular}{|c|c|c|}
\hline 日 & 検査など & 患者の反応 \\
\hline 1 & 入院 & S. 食欲は落ちたがなんとあない \\
\hline 2 & & S。元気になったから退院したい \\
\hline 3 & $\mathrm{C} \mathrm{T}$ & S。早く手術をして帰りたい \\
\hline 4 & エコー & （下剂服用後）S。腹が少し痛い \\
\hline 5 & 注腸 & S. 来週手術になると思っていた \\
\hline 10 & $\mathrm{CF}$ & S. 吐気がした 早く帰りたい \\
\hline 11 & 高血糖 & ( $295 \mathrm{mg} / \mathrm{dl}$ ，インシュリン開始） \\
\hline 12 & 低血糖 & （冷汗）S。俺を殺す気か \\
\hline 13 & 手術延期 & S。先生と俺じゃ位が違うんだ \\
\hline 14 & 日変血糖 & S. あう全く変わりないよ \\
\hline 15 & 無断外泊 & S.今日はどうしてあ家に帰るんだ \\
\hline 16 & 㷌院せず & S. 病院に戻りたくない \\
\hline 17 & 退院 & （家族来院）S。野菜を作っている \\
\hline
\end{tabular}

患者が治療を受け入れられなかった原因は 
治療方針の説明不足, 患者の理解力の低下に 加え患者自身の頑固な性格にあるとしていた。 しかし，看護婦側にも原因の一端はなかった のかという反省を元にあう一度看護介入につ いて見直す必要があると思われた。検証にあ たっては特に患者の心理社会面に焦点を当て るためロイ適応モデルの看護過程を使用した。 第一段階：患者行動を看護記録から医療者 の説明に対する患者の反応に重点をおいて分 析した。その結果患者はほとんどの場合自身 の病気には目を向けようとはせず家に帰る事 ばかりを訴えていて不適応状態にあった。

第二段階：影響因子を次のように査定した。 焦点刺激…手術への恐れ

関連刺激…糖尿病コントロールへの危惧 医療者に対する劣等感

残存刺激…以前から不安状況には怒りや拒否 で対処してきた

第三段階：問題は自己概念における自己一 貫性の問題「不安」にあるとした。さらにそ の中でも役割機能様式においては患者役割失 敗，相互依存様式に拈いては手術拒否之いう 独立行動に陥っていると查定した。

第四段階：目標と介入を次のようにあげた。 目標…手術への恐れ, 糖尿病コントロールヘ の危惧, 医療者に対する劣等感などの 不安について語ることができる。

介入 1. 患者が看護婦から温かさ, 信頼, 関 心, 安心という雾囲気を感じられるように 環境を作り出す。

2. 患者の怒りは看護婦に個人的欲求不満か らぶつけられるのではない事を認識する。

3. 看護婦は患者に対して自分がどう対応し ているのかを常に確認する。

4. 不安について語るてとをためらったり， 決まりが悪いと感じている患者に看護婦か
ら言葉の糸口をきる必要がある。

5. 「機嫌が悪そうですが何か心配なととが あるのですか？」と直接患者に質問する。

6. 患者が会話を拒否した時も都合の良いと きはいつであ話し合いたいという気持ちを 表現しておく。

7. 患者自身が不快な不安の原因を語るとと により不安のエネルギーが軽減する。

8. 患者が不安と対峙することにより患者自 身が前向きな方法で不安に対処することを 桌守り，必要な時は助ける。

第五段階：看護介入の有効性の評価

以上の検証から患者は充足しなければなら ない最大のニード「不安」に対応できず，ま たそれをあ表現できない苦しさにあったと思 われる。ここでは患者の説得よりまず患者が 知識を受け入れられる状態かどうかを判断す ることが先決であった。

\section{V. 結論}

患者の自己退院をロイ適応モデルにおける 不安という看護問題として捉えこれに基づく 看護介入を試みていたならば，患者は役割遂 行と相互依存がとれ，その結果あるいは自己 退院は回避出来たかもしれない。

VI。まとめ

ロイ適応モデルに沿って検証を進めるうち に, 病気についての理解力がそしく治療を拒 否した患者像から，様々な不安を抱えてそれ に適応できず手術を拒否し自己退院するとい う負の形でしか適応せざるをえなかった患者 像に変化していった。また，てういう患者て そ看護独自の視点と介入によって救われるべ きであるととを知った。今回は看護介入方法 の提示までなので, 今後結果・評価・修正ま でを含めた症例研究が必要である。 
$1 \mathrm{C} 01$ 剖検からみた突然死 〜 35 例の検討〜

(带広厚生病院病理) ○山口潤, 若原幸枝, 小泉直美, 塩崎正樹, 田村裕恵

\section{（同第二内科）鹿野泰邦}

突然死の疫学的検討については、多数の症 例を扱っている監察医務院よりの報告をはじ めとして、法医学領域で多くの報告があるが、 今回は、第一線の医療機関において剖検で死 因を確定しえた突然死症例を検討したので報 告する。

\section{【方法と対象】}

過去 6 年間の帯広地区の 2 病院（带広厚生 病院、带広協会病院）で解剖された441例中 15歳以上で、1）致命的な発症を目撃してい るもの、または、病院に般送され加㾌される、 もしくは病院到着時既に死亡している例で発 症から死しまでが24時間以内のもの、2）死 亡後発見されたものであるが、その状況から 急激な発症が推湘されるもの、の35例を対象 にした。

\section{【結果および考察】}

1. 年㱓、性：年跉的には、26〜85歳（平 均63.8歳）であり、年代別には70歳代がもっ とも多く、ついで60、80歳代であった(表 1 )。 男女別には、男21、女14であった（表 2 ）。

2. 死因 : 死因別では、急性心筋梗塞がも つとも多く18例であり、心筋梗塞例に限ると 男女比は男13、女 5 であった。また陳旧性梗 塞を伴わないもの 6 例、伴うものは 12 例と陳 旧性梗塞を伴う例が多かった。その他の死因 としては、心病変を伴ったサルコイドーシス 1、アミロイドーシス 2 、心弁膜症 2 、大動 脈瘤破裂 6 、解離性大動脈瘤 1 、肺動脈塞栓 症 4、原因不明のポックリ病 1 であった（表

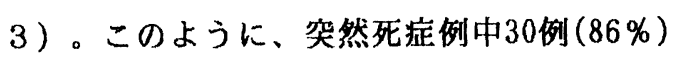

は心・血管系の復環器疾患であり、心筋梗塞 はそのうち $60 \%$ を占めていた。これらの成績 は大阪府監察医事務所の報告とほぼ一致する ものと思われた。呼吸器系疾患は肺動脈塞栓 症が 4 例で全体の $11 \%$ を占めた。通常 $15 \%$ 前 後を占めると考えられる脳血管系疾患は、今 回の症例には含まれていなかったが、その理 由としては、当院に脳外科がなく、患者の般 入段階ですでにふるいがかかっていたものと 考えられた。

3.月别、時刻別例数: 月別にみても季節 別に見ても、特に寒い時期に多いという傾向 は見られなかった（表4）。また1日のうち の発症時刻を 3 時間ごとに見ると、心筋梗塞 死はどちらかというと樑夜から朝方にかけて 多い傾向が伺われた（表 5)。

4. 発症から死亡までの時間 : 致命的な発 症から死亡までの時間を調べると、発症後 5 分以内の瞬間死が20例 (57\%) と多かった。 心筋梗塞例の $78 \%$ は発症から 3 時間以内に死 亡しており、中でも瞬間死は 9 例 $(50 \%)$ と 多かった（表6）。

5. 発症時の行動: 発症時の行勤は、就安 中 3 、安静時 18 、作業中 5 （農作業中 3 ）、 歩行中 3 、用便中 2 、会議中 1 、電話中 1 、 洗寢中 1 、入浴中 1 であった（表 7)。心筇 梗塞死の 9 例 $(50 \%)$ は睡眠中あるいは安静 時に発症しており、ついで歩行中 3 例、作業 中 2 例などとなっており、必ずしも発症が強 い運動、労働に関係しているとはいえなかっ た。 


\section{【結語】}

突然死症例を年代別に検討すると70歳代が もっとも多く、ついで60歳代であつた。男女 別には、男21、女14であった。

突然死剖検例を死因別に分析すると、心・ 血管系疾患は 30 例で全体の $86 \%$ を占めた。心 筋梗塞は18例で心・血管系疾患の60\%であり、 男性に多かった。

呼吸器系疾患は肺動脈塞栓症が 4 例で全体 の11\%を占めた。

\section{【文献】}

1)徳留省悟，山口吉䯞 : 剖検よりみた予期せ さる急性死の死因分析．臨床科学 25 ：

671-678, 1989.

2)的場梁次, 藤谷 登, 吉田謙一, 他 : 心矂 急死の疫学的、ならびに虚血性心疾患を主 とした組織学的研究。心眼 $21: 1022-103$ $0,1989$.

3) 落合光雄 : 成人の内因性急死の統計的観察. 日法医誌 $18 ： 46-75 ， 1964$ 。
表. 1 . 突然死の年代別分布

\begin{tabular}{|ll|c|}
\hline 年代 & 突然死 \\
\hline 2 & 0 & 1 \\
3 & 0 & 2 \\
4 & 0 & 2 \\
5 & 0 & 4 \\
6 & 0 & 7 \\
7 & 0 & 1 \\
8 & 0 & 5 \\
\hline
\end{tabular}

表. 2. 突然死の男女別分布

\begin{tabular}{|c|c|}
\hline 性 & 突然死 \\
\hline $\begin{array}{l}\text { 男 } \\
\text { 女 }\end{array}$ & $\begin{array}{ll}2 & 1 \\
1 & 4\end{array}$ \\
\hline
\end{tabular}

表. 3. 死因

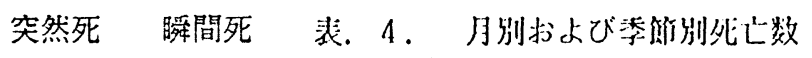

\begin{tabular}{|c|c|c|}
\hline $\begin{array}{l}\text { 急性心筋梗塞 } \\
\text { 陳旧性梗塞なし } \\
\text { 陳旧性梗塞あり } \\
\text { 心サルコイドーシス } \\
\text { 心アミロイドーシス } \\
\text { 心弃膜症 } \\
\text { 大動脈溜破裂 } \\
\text { 解離性大動脈瘤 } \\
\text { 肺動脈塞栓症 } \\
\text { ポックリ病 }\end{array}$ & $\begin{array}{lll}18 & 8 \\
& & 6 \\
& 1 & 2 \\
1 & \\
2 & & \\
2 & & \\
6 & & \\
1 & & \\
4 & & \\
1 & & \end{array}$ & $\begin{array}{l}9 \\
6 \\
3 \\
1 \\
2\end{array}$ \\
\hline
\end{tabular}

\begin{tabular}{|l|cccccccccccc|}
\hline 月 & 1 & 2 & 3 & 4 & 5 & 6 & 7 & 8 & 9 & 10 & 11 & 12 \\
\hline & 8 & 3 & 1 & 1 & 4 & 2 & 4 & 3 & 4 & 2 & 3 & \\
\hline
\end{tabular}

表. 5。発症時刻

\begin{tabular}{|c|c|c|c|c|c|c|c|}
\hline$\sim 3$ & $\sim 6$ & $\sim 9$ & $\sim 12$ & $\sim 15$ & $\sim 18$ & $\sim 21$ & $\sim 24$ \\
\hline 1 & 5 & 6 & 7 & 7 & 5 & 4 & \\
1 & 5 & 3 & 3 & 3 & 2 & 1 & \\
\hline
\end{tabular}

表. 6. 発症から死亡までの時間

下段沁心筋梗塞死

\begin{tabular}{|c|c|c|c|}
\hline$\sim 5 \min$ & $\sim 3 \mathrm{hrs}$ & $\sim 12 \mathrm{hrs}$ & $\sim 24 \mathrm{hrs}$ \\
\hline 20 & 9 & 4 & 2 \\
9 & 5 & 2 & 2 \\
\hline
\end{tabular}

表. 7. 発症時の行動

\begin{tabular}{|l|r|}
\hline 就蔓時 & 3 \\
安静時 & 18 \\
作業中 & 5 \\
歩行中 & 3 \\
会便中 & 2 \\
会議中 & 1 \\
電話中 & 1 \\
洗髣中 & 1 \\
入浴中 & 1 \\
\hline
\end{tabular}

下段活心筋梗塞死 


\section{$1 C 02$ 長野県佐久地域における心筋梗塞の発症状況について} 第 3 報

○高松道生、高木一生（長野県・佐久総合病院） 磯村孝二（長野県・北信総合病院）

[はじめに $]$

農村地域である南佐久郡・佐久市における 心筋梗塞の発生状況を引続き調査し、年齢・ 危険因子などの疫学的分析を行った。またこ のフィールド内症例を中心とした当院の院内 症例についても検討し、高粭発症症例の予後 について考察した。

\section{[対象および方法］}

八ヶ岳山麓に展開する野菜栽培を中心とす る高原地帯である南佐久郡 8力町村と、隣接 する小都市の佐久市、合わせて人口11万人の 農村地域をフィールドに設定し、1989年04月 から1992年03月までの 3年間における心筋梗 塞発生状況について登録を行った。

発生状況の把握は地元医師会である佐久医 師会、およびフィールド内の 5 病院に報告を 依頼し、佐久総合病院においてまとめ及び医 療機関への照会・調查を行った。心筋梗塞の 登録条件として、胸部症状 - 心電図異常 - 血 清酵素 (CK) 上昇の 3 者を満たしたもの、あ るいは剖検による確認の得られた症例のみ登 録を行い、疑い例は除外した。

院内症例は1980年 5 月から1982年 5 月に当 院にて急性期管理を行った新鮮心筋梗塞症例 連続 427例とし、高齢発症症例の予後につい て検討した。

\section{[結果 ]}

1)フィールド内での登録症例について

(1)心筋梗塞登録は1989年 4月から1990年 3月 までの' 89年度一年間では38例、同じく'90年 度 48 例、' 91 年度 40 例と、この3年間の心筋梗
塞登録数はほぼ同じ水準であり、合計 126 例 （うち2例が再発）・124名であった（人口10 万対比 $=38.2$ /年 $)$ 。またこの 3 年間の経過を 通じて当院への紹介転送患者が増加しており、 登録症例に占める当院入院症例比率が増加し ている。（当院登録比率一' 89 年度 $=55.2 \%$ 、 ' 90 年度 $=81.8 \% 、 ' 91$ 年度 $=85.0 \%$ ）。

(2)男女別では男90名、女36名と男女比が 2.5 となっており、'91年4月以降男性例が多かっ たためその差が開き、全国水準に近づいてい る。(3)平均年齢は男 66.1 才、女75.6才（合計 平均68.8才）と、女性の平均年路が男性より 約10才高く、大きな差が認められている。全 症例中 80 才以上の高齢者は 32 名 $(25.4 \%)$ を 占めた（男性15例 $=16.7 \%$ 、女性 17 例 $=47.2 \%$ ）。 (4)既往歴では高血圧が 59 例 $(46.8 \%)$ と多か ったが、男性42例（46.7\%）・女性17例（47. $2 \%$ ）と男女差は認められなかった。

(5)高脂血症 (総コレステロール $220 \mathrm{mg} / \mathrm{d} 1$ 以上 ）は24例 (19.0\%) と少なかったが男性14例 （15.6\%）、女性10例（27.8\%）と男女差が認 められた。

66過去を含めると喫煙歴が 68例 (54.0\%) に 認められ、男性61例（67.8\%）・女性 7例（1 9.4\%）といずれも全国平均を上回っているが、 最近は減少傾向となっている。

(7)発症後 4週以内の急性期死亡は14例（11.1

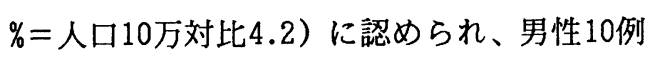
(11.1\%) ·女性 4例 (11.1\%) と全く同じ死 亡率であり、女性例の死亡率低下が著名であ

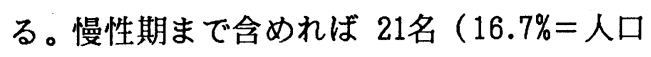


10万対比 6.4）の死亡が認められたが、男性 12例 (13.3\%) ·女性 9例 (25.0\%) と明らか な男女差が認められた。

(8)一年以上経過した急性期生存例85例の調査 では、死亡 7 例 $(8.2 \%)$ 、生存67例、消息不 明11例（追跡率78.8\%）であった。

2)院内症例について

1980年 5月から1992年 5月まで当院で急性 期治療を行った心筋梗塞患者連続 427例を対 象とした。高齢発症は75才以上、80才以上の 2 群を対象とした。これらの症例を救命救急 センター発足まで（1987年 5月）の212例 （年33.0例）=前期群と、それ以降の 215 例 (年42.3例）=後期群とに分けて検討を加え た。

(1)全症例の男女比は約 2.0 と男性に多いが全 国平均（3.0）に比し女性例が多く、高撂者 人口が多い農村地域の特徵を反映しているも のと考えられる。

(2)発症 4週間以内の急性期死亡は80例で全体 の18.7\%にあたるが、男性41例（14.3\%）、女 性 39例（27.7\%）と著明な男女差を認めた。 (3) 75 才以上の症例は前期群 $31.1 \%$ 、後期群 3 $5.8 \%$ 、80才以上の症例は前期群 $15.1 \%$ 、後期 群 $20.5 \%$ といずれも増加を示し、高齢発症の 心筋梗塞が増加していることを裏づけている。 (4)発症 4週間以内の急性期死亡は前期群 26 . $4 \%$ 、後期群 $9.8 \%$ 著明な改善が認められるが、 この改善は、75才以下: $7.5 \% \rightarrow 5.0 \% 、 75$ 才以 上 : $39.4 \% \rightarrow 13.0 \%$ 、80才以上 : $59.4 \% \rightarrow 9.1 \%$ と高齢者群により顕著であった。

(5)慢性期死亡は前期群 15.6\%、後期群 10.7\% と若干の改善が認められるが、80才以上の高 齢者では $1.9 \% \rightarrow 4.2 \%$ とむしろ増加している。 (6)梗塞部位別では前壁198例（46.4\%）、下壁 177例 (41.5\%) と差がなかったが、急性期死
亡は42例（21.2\%）、25例（14.1\%）と前壁例 の死亡率が高かった。

(7)脂質代謝と急性期死亡の検討では、総コレ ステロール・HDLコレステロール・中性脂肪 のいずれとも有意な相関が認められなかった。 [考察およびまとめ]

人口11万人の農村地域における心筋梗塞発 生把握を行った。人口10万対比での発生数は 38.2 年であり、急性期死亡が 4.2 /年、他疾 患による慢性期死亡までを含めれば6.4/年で あった。この数字は厚生省の統計（39.9/年） に比べ、一桁少ないものであるが、同時期で の人口10万人あたり 24.6 人/年に及ぶ内因性 急死例の取扱いがこの結果に大きな影響を及 ぼすと考えられる。急死例の死因特定は困難 を伴うことが多いがこの中に心筋梗塞が含ま れていること、また逆に内因性急死例の中に 解離性大動脈瘤・肺塞栓症などが含まれてお り、これらが「心筋梗塞」と診断されている こと、この両者が厚生省統計と我々の調查と の解離の原因になっていると考えられる。

次に院内症例の検討では、心筋梗塞患者に 占める高秢者の割合は増加しつつあるが、急 性期予後は高齢者ほど改善しており、この要 因として急性期治療の向上のみならず軽症の 高齢者心筋梗塞患者が増加している可能性も 否定できないと考えられる。従って高齢発症 例であっても、非高酫者と同様の積極的な治 療を行うことで急性期予後の改善が期待でき るものと考えられる。

しかし、一方で急性期を乗り切った症例の 慢性期予後は高齢者でむしろ悪化しており、 高齢発症心筋梗塞症例に対する慢性期医療の 課題と考えられた。 
検診時不整脈出現者 $の$ 生命子後

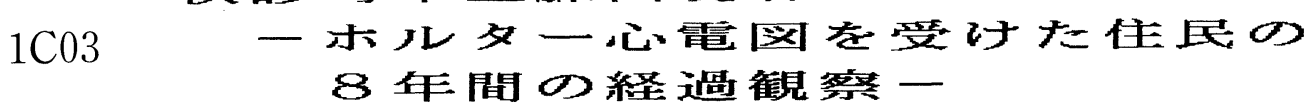

○榎本 信雄、都築 龍、横田 敏範、倉澤 豊身

松永 勇人、工藤 賢治（内科）、岡 昭（外科）

山本 久美、仁科扶支子、桑原 愛子（臨床検査科）

児玉 美鈴（健康管理課）（静岡厚生病院）

$<$ 目 的 $>$

検診での心電図検查において、不整脈 などの異常を指摘され、Holter心電図検 查を施行された住民に予後調查を行い、 循環器精検が生命予後をどの程度まで推 定できるかを検討した。

<方 法>

静岡県中部地域の昭和 60 年度におりる 循環器検診受診者は 5,654 名であつた。こ のうち、心電図にて不整脈をはじめとす る心電図異常を指摘され、Holter心電図 を含む精検が行われた 310 名（男196名、 女114名）につき、平成 4 年 6 月に郵便お よび電話により尒後調查を施行した。

\section{<結 果>}

Hol ter心電図検查の精検後予後調查を 施行した対象者の性・年齢別構成は表 1 に示すとおりである。310名の对象者のう ちで、転居などにより10名の予後が追跡 不能であり、追跡可能者は 300 名 (追跡率 96.8\%）であった。追跡期間中に4名の 死亡があつた。1例は完全右脚ブロック 十左軸偏位と心拡大を伴う60歳の女性で、 心筋㱨の疑いにて over driving supression test 施行し、HVの軽度延長 があり、心室性期外収縮も出るため抗不 整脈薬を内服中であった。3 年半前语尿 器科で尿失禁の手術を受けた後元気であ つたが、仕事中に急死した。1例は38歲 の男性で心電図上左室肥大があるものの 心エコー、Holter心電図では特に異常を みなかつた。日常生活でも異常はなかつ たが、2 年前脳出血をおこし死亡した。 1 例は陳旧性肺結核の77歳の男性で、 Holter心電図で上室性期外収縮の連発と
心室性期外収縮の 3 連発があり、左肺は 癒着により、ほとんど機能していなかっ た。 6 年前膿胸による呼吸不全にて死亡 した。最後の 1 例は68歳の男性で、 Holter心電図で上室性期外収縮の散発が あつたが、日常生活では特に異常もなく 元気であつた。 5 年前、交通事故にあい 死亡した。

現在、循環器疾患にて医療機関を受診 しているものは表 2 に示すとおりであり、 心贜弁膜症例は 6 例、不整脈症例は 8 例 あつた。また、心房細動などで長い $\mathrm{R} R$ 間隔を有する症例にペースメーカー植え 込み例が 3 例あつた。また、脳梗塞を発 症した 3 例のうち 2 例が lone af と考 えられていた症例であり、現在医療機関 を受診せず日常生活に異常のない253名 中 lone af は 2 例あり、これらの症例 の今後の経過観察および治療の重要性が 考えられた。 <考 察>

循環器精検時のHolter心電図において、 すぐに治療に役立つような情報が得られ ることは少なかつたが、他の循環器精検 と合わせ施行することにより、経過観察 および治療必要者をより的確に把握でき る検査であると考えられた。

<結 語〉

昭和 60 年度の循環器検診受診者 5,654 名 において、Holter心電図検查が施行され た 310 名を対象として、平成 4 年 6 月に予 後調查を施行し、300名の現況を追跡でき た。死亡例 4 名と医療機関受診中の 43 名 の異常の内容を表 2 に示した。残りの 253名は日常生活に異常はみられず元気に 
生活していた。今後ともHolter心電図検 の的確な把握と指導をしてゆきたい。 查を含めた循環器精検を実施し、異常者

表 1. 対象者の性・年䟦別構成

\begin{tabular}{lrrrr}
\hline \multicolumn{1}{c}{ 年 } & 䤭 & 男 & 女 & 計 \\
\hline $20-29$ & 歳 & 7 & 4 & 11 \\
$30-39$ & 歳 & 28 & 16 & 44 \\
$40-49$ & 歳 & 49 & 24 & 73 \\
$50-59$ & 歳 & 56 & 42 & 98 \\
$60-69$ & 歳 & 51 & 26 & 77 \\
$70-79$ & 歳 & 5 & 2 & 7 \\
\hline
\end{tabular}

表 2. 追跡期間中の主な異常

\begin{tabular}{|c|c|c|c|c|}
\hline 主を & 異常 & 男 & 女 & 計 \\
\hline \multirow[t]{5}{*}{ 死 } & 亡 & & & \\
\hline & 心筋症疑い & & 1 & 1 \\
\hline & 脸出血 & 1 & & 1 \\
\hline & 膿胸 & 1 & & 1 \\
\hline & 交通事故 & 1 & & 1 \\
\hline \multicolumn{5}{|c|}{ 循環器疾患 } \\
\hline & 心臓弁膜症 & 3 & 3 & 6 \\
\hline & 不整眽 & 5 & 3 & 8 \\
\hline & ペースメーカー植え込み & 2 & 1 & 3 \\
\hline & 心筋梗塞 & 1 & 1 & 2 \\
\hline & 狭心症 & 2 & & 2 \\
\hline & 脳梗塞 & 3 & & 3 \\
\hline & 脳出血 & 1 & & 1 \\
\hline \multicolumn{2}{|c|}{ 高血圧症 } & 6 & 5 & 11 \\
\hline \multicolumn{2}{|c|}{ 循環器系以外の疾患 } & 4 & 3 & 7 \\
\hline
\end{tabular}


再梗塞を予防し、社会復帰に向けての援助を考える

$1 \mathrm{C} 04$ 〜 病識のない重度の心筋梗塞患者

家族への日常生活指導を通して〜

○松村厚子 水越智子 君島とし子

米島 京子 （総合病院 猿島協同病院）

1.はじめに

心筋梗塞患者の中には再発作や合併症の増 悪などで入退院を繰り返すことが少なくない。 その理由としては、疾患の理解が不十分であ ったり、社会的地位の保持や経済的な欲求を 満たすための、過剩労働に陥っているため生 活全般にわたる自己管理が困難であると考え られる。今回内科病棟で出会ったA氏は、自 覚症状がないことから病気を軽視してしまい、 全く理解のないまま気楽な生活を送り、生活 改善を受容できずに入院を繰り返していた。 再発を予防するための生活改善を行うには、 意志、知識を判断し家族の協力を得て、具体 的な方法で継続して指導する必要がある。A 氏が疾患を受容し、積極的に自己管理ができ るようになればと思い、この症例に取りくん た。

\section{2.事例紹介}

患者紹介

69才 男性 頑固な性格

既往症

昭和 59 年 5 月 陳旧性心筋梗塞にて入院 合併症

高血圧、僧帽弁腱索断裂、気管支喘息 入院までの経過

平成3年7月16日朝方、胸痛出現。ニト ロペン舌下するも改善せず、当院受診。 ECGにて急性心筋梗塞と診断され、入院 となる。
3.看護の展開

$<$ 問題点 $>$

病識不足により、食事・飲水制限の自己管 理ができない。

<看護目標>

(1)疾患について理解させる。

(2)食事制限、水分制限の必要性について理 解させる。

\section{4.看護の実際}

(1)について

心筋梗塞の再発作の危険性について、主治 医から本人・家族に繰り返し説明されていた が、A氏は自覚症状がないことから安静度が 守られていなかった。そこで私達はパンフレ ットを作成することにした。「心筋梗塞とは」 「心筋梗塞の症状について」「日常生活の注 意点」という内容である。

(2)について

1 日飲水量 $800 \mathrm{ml}$ という制限があるにもかか わらず、飲水量をオーバーしており、それに 伴う体重増加・心不全がみられてきた。そこ で私達は飲水量・尿量チェックを行うと同時 にパンフレットを用い、本人・妻への指導を 行った。「飲水しすぎると心臓に負担をかけ、 心機能が悪化してしまう」というような内容 である。

また、食事に関してもカロリー・塩分制限 が守られていなかったため、パンフレットを 作成して指導した。 


\section{5. 考察}

今回の指導を通して、慢性疾患の場合、継 続看護の重要性を学んだ。心筋梗塞のような 疾患は、突然死も多く、退院後の管理が重要 である。とくに食事療法による日常生活、家 族ぐるみの協力態勢が必要なことを認識し、 継続して援助することが大切である。

今後もパンフレットを活用・改善し役立た せていきたいと考えている。

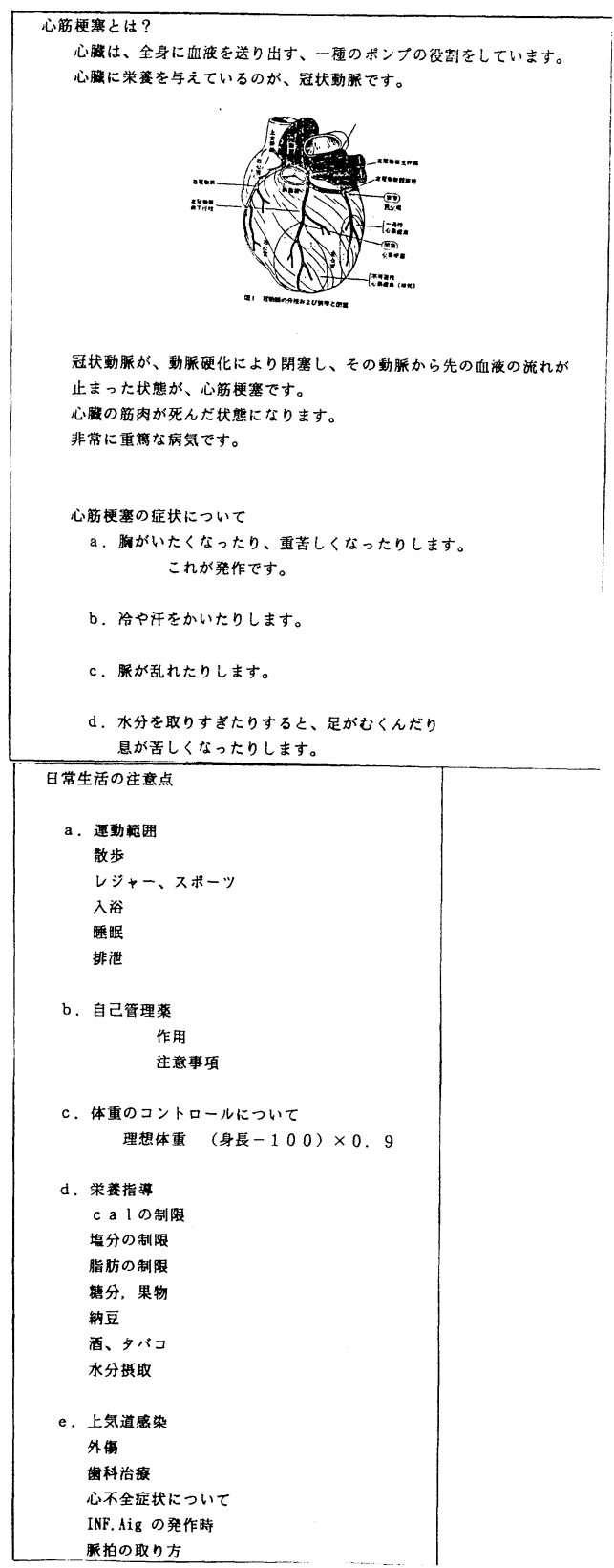

参考文献

1.図解患者指導.メジカルフレンド.1988.

2.特集虚血性心疾患. 臨床看護.17(8).1991.

3. 重点患者の生活指導とセルフケア.急性心筋 梗塞患者の看護.34(9).1988.

4.心筋梗塞についてのパンフレット.土浦協同 病院

5.エネルギー・塩分・蛋白質ガイドブック.女 子栄養大学.1989.
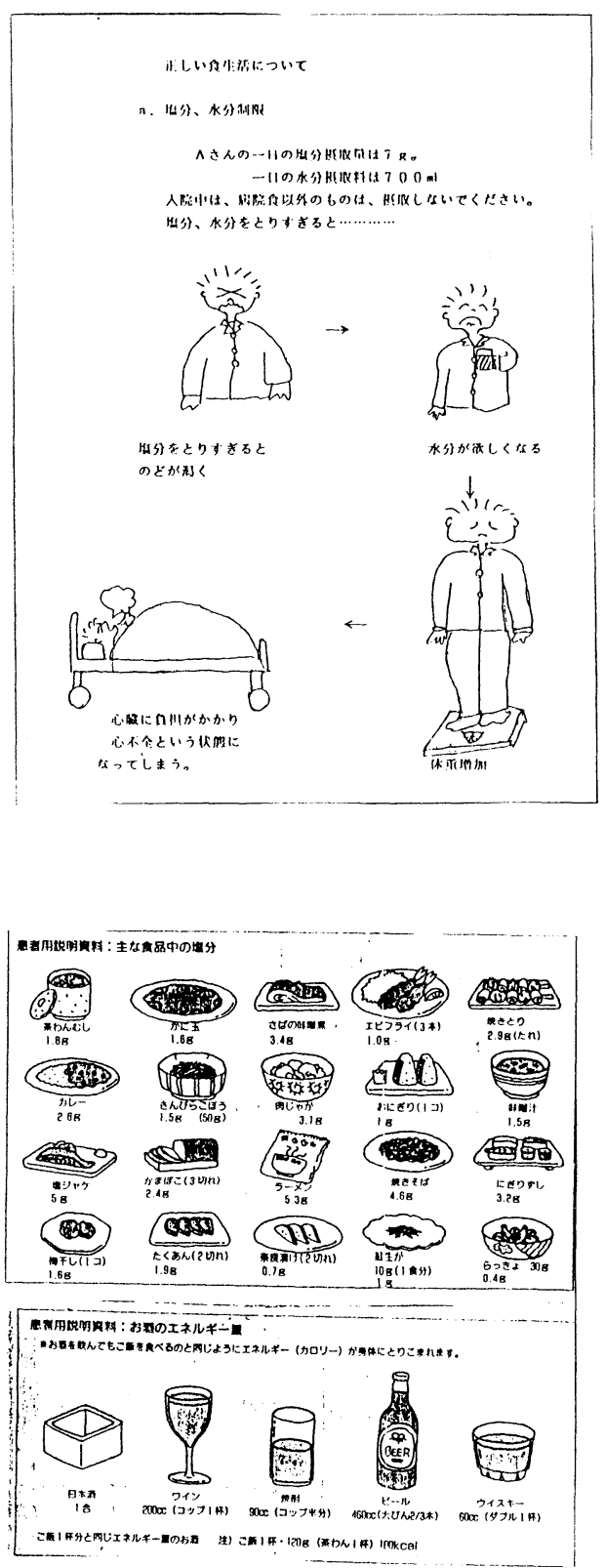
$1 \mathrm{C} 05$

心筋梗塞の運動療法

一回復期監視型運動療法の効果 -

土浦協同病院循環器センター内科

○藤原秀臣, 高橋 淳, 徳永 毅, 全 栄和, 雨宮 浩, 家坂義人, 浅川育世* 岡安利夫*, 高野 勤*, 遠山卓明** (リハビリテーション科*, 臨床検査科 ${ }^{* *}$ )

\section{【目的 】}

心筋梗塞患者が退院後に行う回復期運動療 法は, 社会復帰に向けての運動能力の獲得の みならず再発予防や生命予後の改善にとって 重要である。しかし, わが国に打いては回復 期運動療法を監視型で系統的に行っている施 設は少ないのが現状である。そこで心筋梗塞 患者の回復期に監視型運動療法を実施し, 社 会復帰への効果, 運動耐容能の变化, 心血行 動態の推移などを評価し，その意義と有用性 について検討した。

\section{【方 法】}

対象は 1990 年11月より 1992年 5 月までに 当院 C CU 亿入院した急性心筋梗塞患者のうちの 回復期運動療法適応者 25 例で, 男 23 例, 女 2 例, 年齢は $33 \sim 67$ 歳 (平均 52 歳) である。運 動療法の適応は, 70歳未満で狭心痛がなく, 左心機能が良好で運動療法を理解し積極性の ある症例とした。運動処方は, 症候限界性運 動負荷（トレッドミル）に打ける最大心拍数 の70〜 80\%に相当する運動強度とし, 運動の 方法は自転車エルゴメーター, 運動頻度は週 3 回, 運動期間は $8 \sim 12$ 週とした（表 1 ）。 運動中の最大心拍数, 最大血圧, 最大二重積, Borg 係数を評価し。運動療法開始前と終了 時にはトレッドミルによる運動耐容能, 運動負荷 心エコー法による心拍出量の推移などを評価 し，社会復帰の様相についても検討した。

\section{【結 果】}

(1) 52 例中 23 例 (92\%) が完全社会復帰した。 (2)トレッドミルによる運動時間は $6.9 \pm 1.7$ 分 $\rightarrow 8.7 \pm 1.9$ 分 $(\mathrm{P}<0.001)$ 之有意に増加 した（図 1)。(3)運動療法前後のトレッドミ ルに抢ける心拍数, 血圧, PRPの值に有意 差はなかった。一方, 運動療法前の最大運動 時間之同一時間における運動療法後の心拍数, 血圧，PRPの値はいずれあ有意に低值であっ た（図 2,3)。(4)運動療法に打ける最大心 拍数は 0 週の $123.5 \pm 20.8 /$ 分に比し， 4 週の $117.1 \pm 18.7 /$ 分 $(P<0.05), 8$ 週 $114.1 \pm 18.7$ $(\mathrm{P}<0.005)$ と有意に低值であった。最大血圧 は， 0 週， 4 週，8週の間に有意差はなかっ たがPRPは 0 週 18623 土470亿比し，8週は $17166 \pm 4288(P<0.05)$ と有意に低值であっ た（図 4 )。(5)運動療法に打ける安静時心係 数は不変であったが最大心係数は, 前值 6.01 $\pm 2.08 \mathrm{~L} / \mathrm{min} / \mathrm{m}^{2}$ に比し後値は $3.17 \pm 1.46 \mathrm{~L} /$ $\mathrm{min} / \mathrm{m}^{2}(\mathrm{P}<0.005)$ と有意に低下していた。 一方安静時一回拍出係数は不変であったが, 最大一回拍出係数は前値 $43.9 \pm 8.1 \mathrm{ml} / \mathrm{m}^{2}$ 亿比 し後值は $55.0 \pm 10.5 \mathrm{ml} / \mathrm{m}^{2}(\mathrm{P}<0.01)$ と有意 に増大していた（図 5 )。

\section{【総括】}

監視運動療法は安全に施行でき, 確実な運 動療法効果が得られるなどの利点があるが, 人的要因や施設の設備などが障害となり, 広 く普及していないのが現状である。今回, 心 筋梗塞患者に監視型の回復期運動療法を施行 した結果, 高率な社会復帰が得られ, 全例で 運動耐容能が増大した。また，心血行動態の 改善あ明らかであった。以上のてとより, 本 法は心筋梗塞患者に安全に実施でき, 確実な 
社会復帰にとって有用な方法であると考えら れた。

表 1 運動処 方

運動方法：自転車エルゴメーター

運動強度：最大心拍数の 70 ～ $80 \%$

運動頻度：3 回/週

運動期間：8～12 週
図 1

EXERCISE TIME (Treadmill)

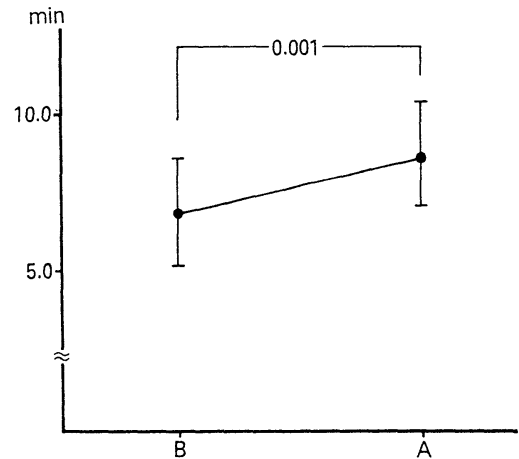

図 3

$\underline{\text { PRP } \max \text { (Treadmill) }}$

図 2

$\underline{\text { S-BP } \max \text { (Treadmill) }}$
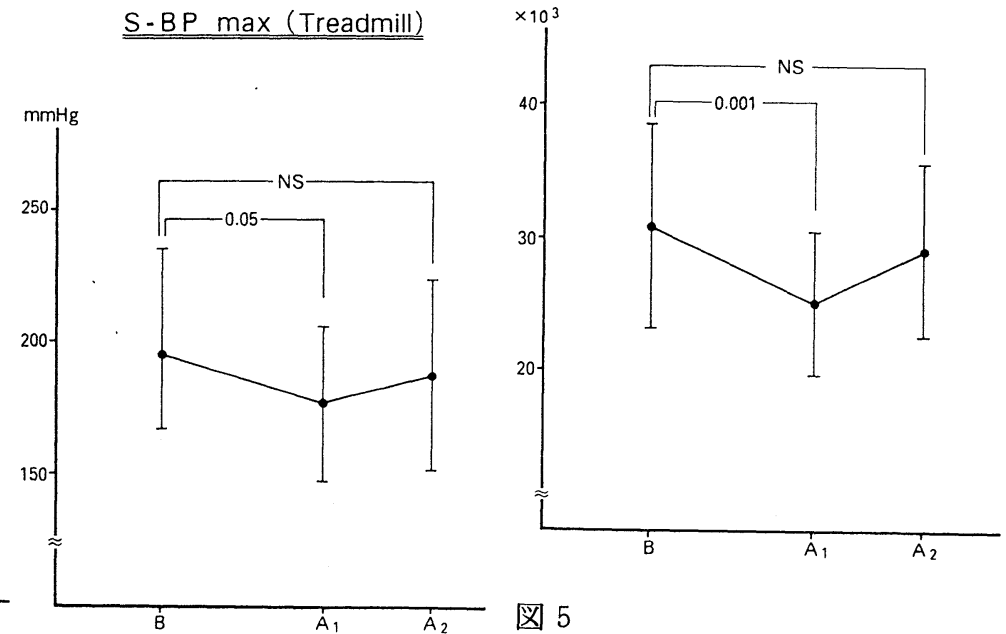

図 5

STROKE VOLUME INDEX (SVI)
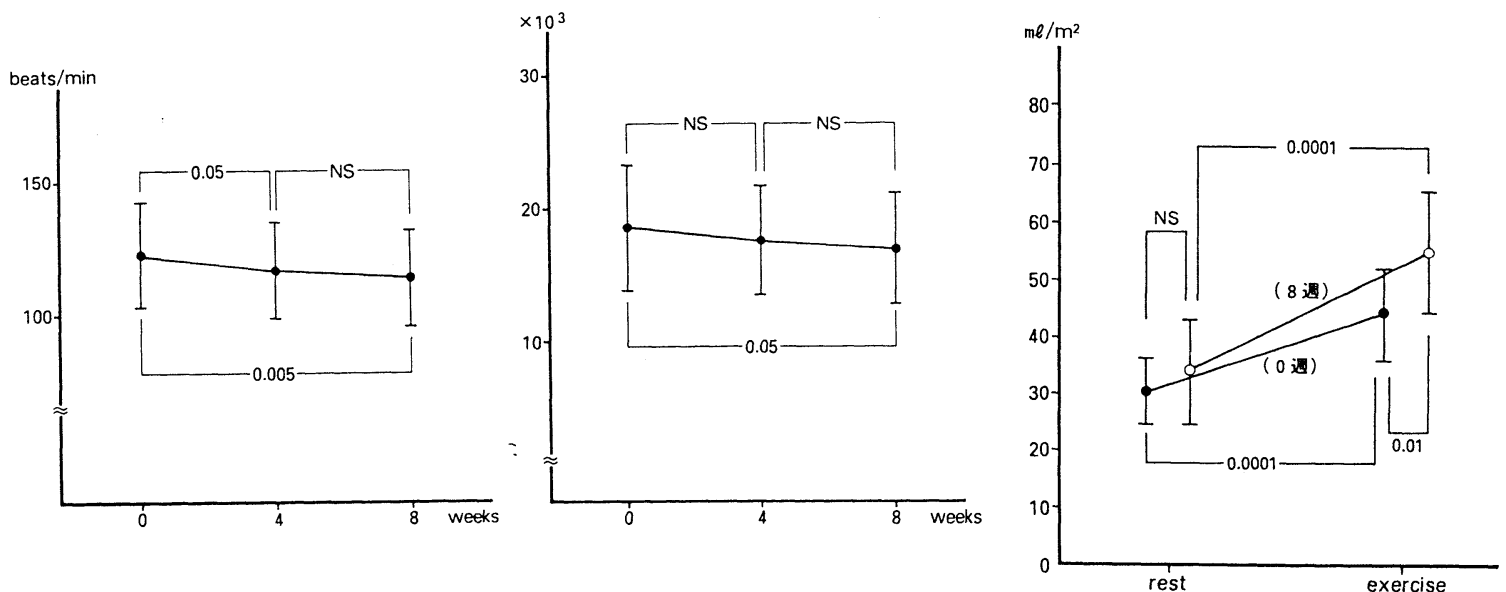

rest 


\section{$1 C 06$ 心エコー法と左室造影法における心筋壁運動評価の一}

○末松太尾関裕一愛宕博梅村喜昭

田中史朗野田勉早川和良 ${ }^{11}$ 新井正 ${ }^{11}$

成宮茂利 ${ }^{11}$ 高屋忠丈 ${ }^{11}$ 安田洋 ${ }^{11}$ 樫木良友 ${ }^{21}$

岐阜県厚生連岐北総合病院放射線科 内科 ${ }^{11}$ 外科 $\left.{ }^{2}\right)$

\section{【はじめに】}

心エコー法は、非侵襲的検査であるため、 容易に頻回検査が可能であり、狭心症、陳旧 性心筋梗塞患者の経時的心筋壁運動の評価に は有用であると思われる。しかし、心エコー 法による心筋壁運動の評価は、主観的なもの が多く、信頼性に問題もあり、いくつかの定 量的評価の方法が試みられているが未だ確立 されたものは無い。今回我々は、煩雑な日常 診療のなかで、我々が行なっている断層心工 コー検査による心筋壁運動の評価が、左室造 影法によるそれと比べ、どの程度の信頼性が あるか否かを検討した。

\section{【対象および方法】}

対象は、1991年 1月から1992年 5月の期間 に当院にて冠動脈造影及び、左心室造影を施 行された安定期にある狭心症、陳旧性心筋梗 塞患者19才〜84才 平均年齢65才、男性 35 例 女性27例とした。表 1 に、62例の冠動脈造影 における病変所見を示す。心エコー検査は、 アロカ社製超音波診断装置 SSD-650、プロ ーブ $3.5 \mathrm{MHz}$ を使用し、原則的に左心室造影 検査前一週間以内に施行した。断層心エコー 検査による心筋壁運動の解析は、同一検者に より、短軸像、長軸像にて A H A 分類の 1 〜 7 区域の各々において肉眼視で評価された。 また、左心室造影法 ( Left Ventriclography：LVG）による心筋壁運動の解析は、 2 名以上の心臓専門医により、centerline methodにより解析された所見を参考にしてお
こなわれた。図 1 に、1 枝病変患者の心エコ 一所見と L V Gによる centerline method の実際を示した。次に1〜 7 区域について、 壁運動の良好なものを正常とし、\{akinesis dyskinesis hypokinesis\}を壁運動異常とし て分類し、断層心エコー検査法による心筋壁 運動の評価の信頼性を検討した。

\section{【結果】}

表 2 に示すように、L V G 法に対する心工 コー法の sensitivityと specificityは、正 常運動で各々 $88 \%$ \% 75 \%であった。異常 運動では $54 \%$ \% $75 \%$ \%あり、異常運動の sensitivity に低値を認めた。表 3 に $1 \sim 7$ 区域の各々の壁運動について、L V Gに対す る心エコー法の sensitivityと specificity を示した。正常運動群では、sensitivity は 84〜91\% 、specificityは、67〜91\%と良好 であった。異常運動群では、seg 1 の specificityが 47 \%であり、seg 5 及び seg 7 の sensitivityが、45\%及び $38 \%$ と低值で あった。

\section{【考察】}

断層心エコー法は、その簡便さ、非侵襲性 から有用な検査であり、虚血性心疾患時の心 筋壁運動の評価が、従来より多く行われてき た。しかしその定量的判定は、色々と試みら れているが、未だ確立されたものは無い。定 性的評価として、心筋の収縮期壁厚増加率に より、壁運動評価を行っている施設 ${ }^{1)}$ もみら れるが、多くは視覚的判定に委ねられている 
のが現状と思われる。今回の我々の成績 では、断層心エコー法による壁運動の評 価は、L V Gと比較すると、壁運動異常 群に sensitivityの低值が認められ、A H A 分類による、seg 5 及び $\operatorname{seg} 7$ の sensitivity が、各々 $45 \% 、 38 \%$ と目立 って低かった。これは、断層心エコ一法 では、必ずしも良好な第一斜位や第二斜 位での像が得られないことと、L V G 法 によるA H A分類の区域と、対応すべき 心エコー法による断層面が一致しない2 ためと思われる。これは心エコー法では 任意に多断面に断層面を決定できるのに 反して、L V G 法は造影された左室の投 影像であるためと考えられる。このため 心エコー法による壁運動評価の. sensitivityをよくするには、詳細な多断面で の判定が必要と思われる。特に高齢者で は、鮮明な像が得られないことも多く、 心エコ一法以外のR I C T MRI等 を利用した心筋壁運動評価方法の開発が 今後ますます必要になると思われる。
表 1 冠動脈撮影所見

\begin{tabular}{|rrr|}
\hline 正常 & & 6 名 \\
1 枝病変 & & 5 名 \\
2 枝病変 & 1 & 4 名 \\
3 枝病変 & 2 & 7 名 \\
計 & 6 & 2 名 \\
\hline
\end{tabular}

表 2 LV Gに対する心エコー法の心筋壁運動評価

\begin{tabular}{|c|c|c|c|c|}
\hline LVG \UCG & 正常䢩针群 & 異常邆動群 & 計 & sensitivity \\
\hline 正常運動群 & 234 & 31 & 265 & $88 \%$ \\
\hline 異常䢙動群 & 77 & 92 & 169 & $54 \%$ \\
\hline 計 & 311 & 123 & & \\
\hline specificity & $75 \%$ & $75 \%$ & & \\
\hline
\end{tabular}

表 3 A H A 区域別の心筋壁運動の評価

\begin{tabular}{|c|c|c|}
\hline 心筋壁運動 & sensitivity & specificity \\
\hline $\begin{array}{ll}\text { seg } 1 \text { 正常運動 群 } \\
\\
\text { 異常運動 群 }\end{array}$ & $\begin{array}{lll}8 & 4 & \% \\
6 & 4 & \%\end{array}$ & $\begin{array}{lll}9 & 1 & \% \\
4 & 7 & \%\end{array}$ \\
\hline $\begin{array}{ll}\text { seg2 正常運動群 } \\
\\
\text { 異常運動群 }\end{array}$ & $\begin{array}{lll}9 & 1 & \% \\
5 & 7 & \%\end{array}$ & $\begin{array}{lll}7 & 2 & \% \\
8 & 4 & \%\end{array}$ \\
\hline $\begin{array}{ll}\text { seg } 3 & \text { 正常運動 群 } \\
& \text { 異常運動 群 }\end{array}$ & $\begin{array}{lll}8 & 9 & \% \\
6 & 6 & \%\end{array}$ & $\begin{array}{lll}6 & 7 & \% \\
8 & 8 & \%\end{array}$ \\
\hline $\begin{array}{ll}\text { seg } 4 & \text { 正常運動 群 } \\
& \text { 異常運動 群 }\end{array}$ & $\begin{array}{lll}9 & 4 & \% \\
5 & 4 & \%\end{array}$ & $\begin{array}{lll}7 & 1 & \% \\
8 & 8 & \%\end{array}$ \\
\hline $\begin{array}{ll}\text { seg } 5 & \text { 正常運動 群 } \\
& \text { 異常運動 群 }\end{array}$ & $\begin{array}{lll}8 & 6 & \% \\
4 & 5 & \%\end{array}$ & $\begin{array}{lll}7 & 7 & \% \\
6 & 0 & \%\end{array}$ \\
\hline $\begin{array}{l}\text { 正常運動 群 } \\
\text { 異常運動 群 }\end{array}$ & $\begin{array}{lll}8 & 7 & \% \\
5 & 7 & \%\end{array}$ & $\begin{array}{lll}7 & 7 & \% \\
7 & 2 & \%\end{array}$ \\
\hline $\begin{array}{ll}\text { seg } 7 & \text { 正常運動 群 } \\
& \text { 異常運動群 }\end{array}$ & $\begin{array}{lll}8 & 9 & \% \\
3 & 8 & \%\end{array}$ & $\begin{array}{lll}6 & 9 & \% \\
6 & 9 & \%\end{array}$ \\
\hline
\end{tabular}

文献

1 ) 宝田明、横田慶之、早 川正德ほか：虚血性心疾患に おける局所壁収縮動態の研究 : 断層心工コ一図法による収 縮期壁原增加の評価: J Cardiography 14:49-58,1984 2 ) Craig Lundgren, MD, Patrick D.V. Bourdillon, MD, James C.Dillon, MD, et al: Comparison of contrast Angiography and Two-Dimensional Echocardiography for the Evaluation of Left Ventricular Regional Wall Motion Abnormalities After Acute Myocardial Infarction: Am J Cardiol;65:1071-1077, 1990
図 1

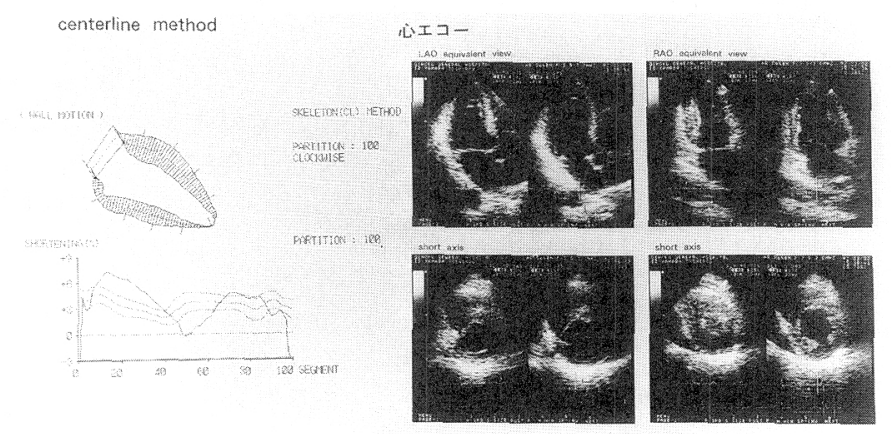




\title{
$1 \mathrm{C} 07$
}

\section{虚血性心疾患患者における心臓カテーテル検査所見と 血清脂肪酸構成の関連について}

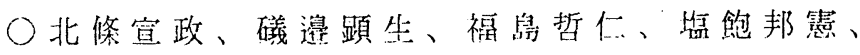 \\ U根洋有（鼻根医大澴境保健医学 II）
}

\section{【研究目的】}

虚和性心疾患と边清コレステロールおよび HDL コレステロールとの䦐連に関して多くの報 告がされてきている。食生活において脂肋椇取 が増加与る中、確实に畮根県住民(血清コレス テロール值比上昇し、女性はほぼ全国平均に達 している。

また最近では、血清中の脂肪酸構成と動脈硬 化との関連、すなおち脳梗塞や虚卹性心疾患と の関連が注目されている。

今回の研究では、虚血性心疾㭧で心血管造影 を行った患者を対象に分画別に脂肪酸構成を測 定し、特に動脈硬化との関連が注目されている パルミチン酸（C16:0）、オレイン酸（C18 :1）、リノール酸（C18:2）と、抗血栓作用お よび血小板凝集抑制作用を持つとされるエイコ サペンタエン酸（C20:5）、さらにナ゚ロスタグ ランディン前駆物質であるアラキドン酸（C20 :4）や、このアラキドン酸のプロスタグラン デインへの変換を阻害するとされているドコサ ヘキサエン酸（C22:6）に注目して、主要冠動 脈狭窄のグレード分類に対忍して比較を行つ た。さらに血清脂質や血清タンパク質などの栄 筶およびこれら分画別脂肪酸棈成と虚血性心疾 患との関潇性を検討したので執告する。

\section{【研究方法】}

対象は1990～1991年にかけて島根県立中央病 院で虚血性心疾患のため心血管造影検查を行っ た50〜70歳代の男性の患者20人である。

採血好早朝空腹時に行い、必要な臨床情報收 集は、患者または家族に対し、直接看詠婦また は医師による問診によって行った。

心血管造影によるグレード分類は、 $75 \%$ 以上 の狭䆶を有意上し、有意の狭窄を有する主要血 管の数により4段階( $(0 \sim 3)$ とした。

血清脂質は Folch（1957）の方法に従って抽 出し、薄層クロマトグラフィーにて各分画に分 離した。薄層プレート（SilicaGel 60, Merk, Germany ) は、ノーマルヘキサンノジェチル エーテル/酢酸（80:20:1 v/v）にて展開し た。分離した各分画の脂肪酸は、加水分解し、 メチルエステル化後、ガスクロマトグラフ

(G3000, Hitachi Industry Co. ITD., Japan) にて分析した。カラムは、HR SS-10 キャピラ リーカラム $(50 \mathrm{mx} 0.25 \mathrm{~mm} \mathrm{ID,} \mathrm{Chromato}$ Packing (enter, Kyoto, Japan)、検出器は F
IDを使用した。カラム温度は、150 $\rightarrow 220{ }^{\circ} \mathrm{C} に$ $3{ }^{\circ} \mathrm{C} /$ 分で昇温し、キャリアガスは、へリウム で2kg， $\mathrm{cm}^{2}$ の圧で、スプリット比は 1:20 で 行った。脂肪酸のピークの同定は、標準脂肪酸 によるリテシションタイム及びマススペクトロ メトリ--(JMS-D300, JEOLCo. LTD., Japan ) にて行った。脂肪酸構成は、重量\%にて表現し た。

有意差検定は、Student's t-test にて行つ た。

\section{【研究結果】}

対象者を冠動脈血管造影により 4 つのグレー ドに分類したが、各グレードに属する群の特徴 を Table1 に示す。各群間で平均年龄に有意差 は認められなかったが、診断名で、グレード0 は全員狭心症であるが、有意な冠動脈狭窑が認 められた群は殆どが心筋梗塞であった。高脂血 症の治療に関しては、グレード 1 群のうち 1 人 のみがメバロチンを服用していた。

伹清脂質の結果を Table 2に示す。有意な冠 動脈狭窄を有する群がそうでない群と比較し、 血清総コレステロール值及び $\beta$ - リポプロテイ ンが高く、HDL コレステロール值が低い傾问が あったが、有意差が出るまでには至らなかっ た。動脈硬化指数资計算して比較すると、グ レード0とグレード 1 の間で有意差が認められ た。その他卜リグリセライド、燐脂質、遊離脂 肪酸などとの比較では、各グレード間で特徽的 な傾向以諗妨られなった。

血清算白、尿酸、空腹時血糖、ミネラルの結 果をTable 3 に示す。血清アルブミン值の比較 で、有意な冠動脈狭雚を有する群がそうでない 群と比較し、低い傾向がみられ、グレード）と グレード1閒の比較で有意差が認められた。

分画別脂肪酸分析に必要な血清量が確保でき た18名について、総脂質、および燐脂質とトリ グリセライドの雨分画に分けて、それぞれの脂 肪酸構成を各グレード間で比較した (Table 4)。 有意次冠動脈狭窄を有する群がそうでない群と 比較し、総脂質、燐脂質分画とも、アラキドン 酸 (C2.0:1 ( $\omega 6)$ ) が高く、燐脂質分画で、ド コサヘキサエン酸 (C22:6( $\omega 3)$ ) が低い傾问 がタられたが、有意差注認められなかった。

また有意差はなかつたが、燐脂睤分画におい て、有意な冠動脈狭窄を有する群がそうでない 群と毕較し、オレイン酸（C18:1）が低く、リ 
ノール酸（C18:2）が高くなる傾向を示した。 パルミチン酸 (C16:0) およびエイコサペンタ エン酸（C20:5( $\omega 3)$ ) はどの分画において も、特徴的な傾向は認められなかった。

\section{【考察】}

虚血性心疾患と血清脂質との関連に関しては 多くの報告があるが、血清総コレステロール、 $\beta$ - リポプロテイン、HDL コレステロールおよ び動脈硬化指数に関してはこれらとほぼ同様の 結果が得られた。

血清アルブミン值が虚血性心疾患のリスクと 負の相関があることを、Kullerら（1991）が報 告しており、今回の結果でも同樣の傾向が認め られた。低血清アルブミンは、持続性の動脈の 損傷、動脈硬化や血检形成の進展と関連してい るものと考えられる。

血清脂肪酸に関しては、特にエイコサペンタ エン酸の抗血栓作用および血小板凝集抑制作用 に関して、Dyerbergら（1978）が報告して以来 注目されるようになったが、それ以前にも、動 脈硬化患者でパルミチン酸（C16:0）とオレイ ン酸（C18:1）が增加し、リノール酸（C18 :2）が減少したとする報告がなされている。さ

Table 1. Baseline Characteristics of the Study Subjects According to Grade of Significant Stenotic Arteries.

\begin{tabular}{lcccc}
\hline & \multicolumn{3}{c}{ Grade of significant } & stenotic arteries \\
\cline { 2 - 5 } & 0 & 1 & 2 & 3 \\
\hline No. of subjects & 5 & 7 & 5 & 3 \\
Age (years) & $61.6 \pm 3.7$ & $67.4 \pm 4.4$ & $65.6 \pm 6.4$ & $65.0 \pm 3.6$ \\
Angina pectoris (number) & 5 & 1 & 0 & 1 \\
Hyocardial infarction (number) & 0 & 6 & 5 & 2 \\
Hypertention (number) & 2 & 2 & 4 & 2 \\
Diabetic & & & & \\
diet (number) & 0 & 1 & 0 & 0 \\
sulphonylurea (number) & 0 & 1 & 0 & 1 \\
insulin (number) & 0 & 0 & 0 & 1 \\
Obesity (number) & 1 & 0 & 0 & 0 \\
Hepatic disease (number) & 0 & 0 & 0 & 0 \\
Smoking (number) & 3 & 6 & 2 & 2 \\
Drinking (number) & 4 & 2 & 0 & 1 \\
Drus therapy of hyperlipidemia & 0 & 1 (mevalotin)0 & 0 \\
\hline
\end{tabular}

Plus-rinus values are means $\pm S . D$.

Table 2. Serum Lipid Leveis of the Study Subjects According to Grade of Significant Stenotic Arteries.

\begin{tabular}{|c|c|c|c|c|}
\hline & \multicolumn{4}{|c|}{ Grade of significant stenotic arteries } \\
\hline & 0 & 1 & 2 & 3 \\
\hline Total cholesterol $(\mathrm{mg} / \mathrm{dl})$ & $196.6 \pm 22.0$ & $213.8 \pm 41.6$ & $234.6 \pm 52.0$ & $237.8 \pm 71.1$ \\
\hline HDL cholesterol (mg/dl) & $51.2 \pm 21.2$ & $32.9 \pm 8.2$ & $40.2 \pm 9.7$ & $33.3 \pm 6.3$ \\
\hline Atberosclerotic index & $3.5 \pm 1.7$ & $5.7 \pm 1.3 *$ & $5.2 \pm 2.1$ & $6.2 \pm 2.3$ \\
\hline$\beta$-Lipoprotein (mg/dl) & $492.0 \pm 99.9$ & $535.1 \pm 90.0$ & $581.4 \pm 143.4$ & $664.3 \pm 188.7$ \\
\hline Triglycerides (mg/dl) & $128.4 \pm 48.9$ & $123.8 \pm 32.2$ & $110.2 \pm 40.6$ & $144.6 \pm 14.8$ \\
\hline Phospholipids (mg/dl) & $221.6 \pm 27.4$ & $210.4 \pm 25.1$ & $231.6 \pm 24.5$ & $213.3 \pm 39.6$ \\
\hline Free fatty acids (uSq/1) & $510.4 \pm 178.1$ & $432.0 \pm 108.9$ & $525.4 \pm 346.6$ & $428.6 \pm 192.3$ \\
\hline
\end{tabular}

らに最近では、プロスタグランディン前駆物質 であるアラキドン酸（C20:4）や、このアラキ ドン酸のプロスタグランディンへの変換を阻害 するとされているドコサへキサエン酸（C22 :6）と動脈硬化との関連についての報告があ る。総脂質、燐脂質分画における、アラキドン 酸（C20:4( $\omega 6)$ )、燐唱質分画における、ド コサヘキサエン酸（C22:6( $\omega 3)$ ) に関して は、これまでの報告と同椂の傾向が認められた が、燐脂質分画にあいて、有意な冠動脈狭窄を 有する群がそうでない群と比較し、オレイン酸 （C18:1）が低く、リノール酸（C18:2）が高 くなる傾向を示し、これまでの報告と逆の結果 が得られた。また、今回最も注目したエイコサ ペンタエン黹 (C20:5( $\omega 3)$ ) に関してはどの 分画においても、特徵的な傾向は認められな かった。

分画別脂肪酸構成之虚血性心疾患との関連に 関しては、今後さらに検体数を増やして検討す る必要がある。

Table 3. Serum Protein. Uric acid, Fasting Glucose and Minerais of the Study Subjects According to Grade of Significant Stenotic Arteries.

\begin{tabular}{lrrrr}
\hline & \multicolumn{4}{c}{ Grade of significant stenotic arteries } \\
\cline { 2 - 5 } & \multicolumn{1}{c}{0} & \multicolumn{1}{c}{1} & \multicolumn{1}{c}{3} \\
\hline Total protein $(\mathrm{g} / \mathrm{dl} l)$ & $7.1 \pm 0.4$ & $6.6 \pm 0.8$ & $7.4 \pm 0.2$ & $6.5 \pm 0.9$ \\
Alburain $(\mathrm{g} / \mathrm{dl})$ & $4.5 \pm 0.1$ & $3.9 \pm 0.4 *$ & $4.4 \pm 0.1$ & $3.8 \pm 0.7$ \\
Uric acid (mg/dl) & $7.5 \pm 0.6$ & $7.5 \pm 1.7$ & $6.5 \pm 1.1$ & $7.4 \pm 1.1$ \\
Fasting glucose (mg/dl) & $96.6 \pm 12.7$ & $95.5 \pm 12.6$ & $95.6 \pm 9.2$ & $105.7 \pm 27.2$ \\
Na+ (mBq/1) & $139.4 \pm 1.4$ & $138.7 \pm 1.8$ & $140.2 \pm 1.7$ & $139.6 \pm 1.2$ \\
K+ (mEq/1) & $4.2 \pm 0.2$ & $4.4 \pm 0.3$ & $4.1 \pm 0.2$ & $4.5 \pm 0.3$ \\
Cl- (mEq/1) & $102.0 \pm 1.4$ & $103.1 \pm 3.0$ & $101.1 \pm 1.7$ & $105.3 \pm 4.0$ \\
\hline
\end{tabular}

Plus-minus values are means $\pm S$. D.

* $P<0.05$

Table 4. Fatty Acid Composition of the Phospholipids of the Study Subjects According to Grade of Significant Stenotic Arteries.

\begin{tabular}{lcccc}
\hline & \multicolumn{5}{c}{ Grade of significant stenotic arteries } \\
\cline { 2 - 5 } Number & 0 & 1 & 2 & 3 \\
\hline $\mathrm{C} 14: 0$ & $0.5 \pm 0.3$ & $0.4 \pm 0.1$ & $0.4 \pm 0.2$ & $0.4 \pm 0.1$ \\
$\mathrm{C} 16: 0$ & $27.3 \pm 2.7$ & $30.8 \pm 2.5$ & $32.7 \pm 8.5$ & $27.2 \pm 1.8$ \\
$\mathrm{C} 16: 1$ & $0.6 \pm 0.2$ & $0.6 \pm 0.1$ & $0.8 \pm 0.4$ & $0.3 \pm 0.1$ \\
$\mathrm{C} 18: 0$ & $15.8 \pm 1.7$ & $15.1 \pm 1.2$ & $15.7 \pm 4.7$ & $15.4 \pm 0.9$ \\
$\mathrm{C} 18: 1$ & $10.1 \pm 1.4$ & $10.1 \pm 1.2$ & $8.1 \pm 2.9$ & $9.5 \pm 0.6$ \\
$\mathrm{C} 18: 2$ & $12.8 \pm 3.1$ & $14.4 \pm 1.6$ & $13.1 \pm 5.3$ & $17.0 \pm 2.2$ \\
$\mathrm{C} 18: 3(\omega 6)$ & $0.2 \pm 0.04$ & $0.2 \pm 0.1$ & $0.2 \pm 0.1$ & $0.2 \pm 0.1$ \\
$\mathrm{C} 20: 0$ & $2.5 \pm 4.2$ & $0.2 \pm 0.2$ & $0.1 \pm 0.1$ & $0.2 \pm 0.1$ \\
$\mathrm{C} 20: 1$ & $0.3 \pm 0.4$ & $1.1 \pm 1.7$ & $1.7 \pm 2.2$ & $0.5 \pm 0.1$ \\
$\mathrm{C} 20: 2$ & $0.3 \pm 0.2$ & $0.4 \pm 0.1$ & $0.3 \pm 0.2$ & $0.4 \pm 0.1$ \\
$\mathrm{C} 20: 3(\omega 6)$ & $1.7 \pm 0.4$ & $2.1 \pm 0.6$ & $1.4 \pm 0.5$ & $2.3 \pm 0.6$ \\
$\mathrm{C} 20: 4(\omega 6)$ & $6.5 \pm 1.6$ & $7.3 \pm 0.9$ & $6.8 \pm 2.6$ & $8.3 \pm 0.8$ \\
$\mathrm{C} 20: 4(\omega 3)$ & $0.2 \pm 0.1$ & $0.3 \pm 0.1$ & $0.4 \pm 0.1$ & $0.2 \pm 0.1$ \\
$\mathrm{C} 20: 5(\omega 3)$ & $3.6 \pm 0.9$ & $2.9 \pm 0.6$ & $3.8 \pm 1.2$ & $3.0 \pm 0.9$ \\
$\mathrm{C} 22: 1$ & $0.3 \pm 0.2$ & $0.2 \pm 0.1$ & $0.2 \pm 0.3$ & $0.2 \pm 0.2$ \\
$\mathrm{C} 22: 4$ & $0.1 \pm 0.1$ & $0.2 \pm 0.04$ & $0.2 \pm 0.1$ & $0.3 \pm 0.1$ \\
$\mathrm{C} 22: 5(\omega 6)$ & $0.1 \pm 0.1$ & $0.2 \pm 0.1$ & $0.2 \pm 0.1$ & $0.2 \pm 0.004$ \\
$\mathrm{C} 22: 5(\omega 3)$ & $1.7 \pm 0.4$ & $1.3 \pm 0.3$ & $1.2 \pm 0.6$ & $1.5 \pm 0.5$ \\
$\mathrm{C} 22: 6(\omega 3)$ & $10.5 \pm 2.7$ & $8.8 \pm 1.6$ & $10.0 \pm 6.3$ & $9.3 \pm 2.4$ \\
\hline
\end{tabular}

Plus-minus values are means $\pm S$. D. 
急性心筋梗塞再灌流療法効果の予測

一心電図所見飞上る検討一

愛知県厚生連海南病院 内科

○伊藤文哉, 長岡憲保, 内田一生, 菅田忠夫,

\section{三島信彦, 鈴木章八, 長嶋 誠}

急性心筋梗塞に対する再灌流療法の適応の 可否に関しては, 従来, 発症からの時間, 入 院時心電図のQ 波の有無などにより判定され てきた。しかし Q波が存在するにもかかわら ず再疎通により慢性期に梗塞量の縮小を認め るもの, 逆に, $\mathrm{Q}$ 波は認めないものの再疎通 の効果が得られないものなど, その効果は一 定していない。そこで, 入院時心電図よりど のようなパラメーターが再灌流療法の効果の 予測につながるかを検討した。

〈対象及び方法〉昭和 63 年 8 月より平成 3 年 12 月までに当院に入院した急性貫壁性前壁中 隔梗塞例のうち（貫壁性心筋梗塞の診断は， 胸痛が持続し, 心電図胸部誘導上, QRS の終 わりより $0.04 \mathrm{~S}$ の時点で $2 \mathrm{~mm}$ 以上の ST 上昇 が 2 つ以上の誘導で認められることとした）

下記の基準を満たした 18 症例を対象とした。

1 ) 初回梗塞で, 責任病変はAHA分類 Segment 6 or 7 。

2) 入院時心電困で脚ブロックを認めない。

3 ) 初回冠動脈造影 (CAG) でTIMI grade $0-1$ 。

4) 発症後 6 時間以内に PTCR で再蹯通

( TIMI grade $\geqq 2$ )

5) 1 カ月後のCAGで梗塞責任血管が造影遅 延なく開存。

心電図パラメーター及び初回冠動脈造影時の 側副血行（図 1 ）：V1-V6 までの R 波の総和 を $\Sigma \mathrm{R}, \mathrm{V} 1-\mathrm{V} 6$ までの $\mathrm{ST}$ 上昇の総和を $\Sigma \mathrm{ST}$ と定義し, $\mathrm{ST}$ 上昇は $\mathrm{QRS}$ の終わりより $0.04 \mathrm{~s}$ の部位で測定した。また, 側副血行の Grad- ing は図の如く定義した。

梗塞量の指標 (図 2 )： T $1201 \mathrm{SPECT}$ の撮影は下記の条件で施行した。投与量 -

$111 \mathrm{MBq}$, 収集時間 -1 方向 40 秒, 収集間 隔 $-\mathrm{RAO} 45^{\circ}$ より $6^{\circ}$ 毎 30 方向, 画像処理はイメ ージフィルター 9 点スムージング, シープ\& ローガン, カットオフ $-30 \%$, 吸収補正一な ᄂ。

なお, PTCRは, 大腿動脈より $6 \mathrm{~F}$ Judkins 型 カテーテルで行い, ウロキナーゼを 72 万 -96 万単位冠動脈内に注入した。そして, TIMI Grade $\geqq 2$ の再疎通が得られた場合, 再疎通(十)とした。

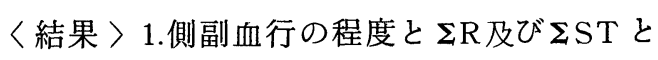
の関係（図 3 ）：側副血行が良行なものと不 良なものとでは $\Sigma \mathrm{R}$ に差を認めなかった。一 方, $\Sigma \mathrm{ST}$ は側副血行が fair 以上のものでは $(-) \sim$ poor のものに比し, 有意に低値であっ

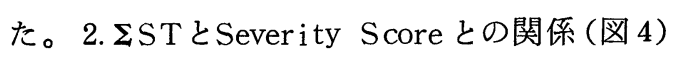
: 上段の図のごとく， $\Sigma$ ST と Severity Score との間には, $\mathrm{r}=0.58$ の有意な相関を認め, 特に, $3-6$ 時間再疎通のものでは, 下段の 図のごとく $r=0.91$ のよい相関を示した。な お， $\mathrm{R}$ と Severity Score との間には有意な 相関は認めなかった。3.図 5 は $\Sigma \mathrm{ST} 2.1$ 以 下と 2.1 以上に区分し, 再疎通の効果を Severity Scoreにより評価したものである。両者 の間には, 病変部位に差を認めず, 発症から 入院までの時間 $(2.6 \pm 0.6 \mathrm{~h}$ vs. $2.1 \pm 0.4 \mathrm{~h})$ 及び再疎通までの時間 $(3.9 \pm 0.5 \mathrm{~h}$ vs . 3.4 $\pm 0.4 \mathrm{~h} ）$ にも有意差はなかった。 $\Sigma \mathrm{ST}<2.1$ 
のものでは, それ以上のものに比し，有意な 梗塞量の低下を認め，さらに， $\Sigma \mathrm{ST}<2.10 も$ のでは側副血行は多くの例で fair以上であっ た。

〈考案〉心筋梗塞に対する再灌流療法は, 梗 塞サイズの縮小ひいては死亡率を低下させる 目的で現在繁用されるようになった。多くの 研究から, 再疎通が発症後 $3-4$ 時間以内に 獲得される場合, その有効性が認められてい る。しかし, 発症後 $3-4$ 時間以上経過して いる場合においても, 再疎通の効果が認めら れる症例が存在し, 側副血行の程度が関与し ていると考えられている。このことから, 再 灌流療法の可否を考える場合, 発症からの時 間だけでなく，いわゆる Preserved Flowの程 度を考慮する必要がある。今回の入院時心電 図の検討から, ST上昇の程度は側副血行の良 否と比較的よく相関し, 心筋虚血の程度を反

\section{図2.〈梗塞量の指標〉}

慢性期（発症後 約1力月）に行なった負荷T1201 SPECT (Bull's eye 法) からSeverity Score を算出 し, 梗塞重の指標とした。

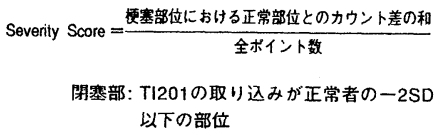

图4. Relation between $\Sigma S T$ and Severity Score
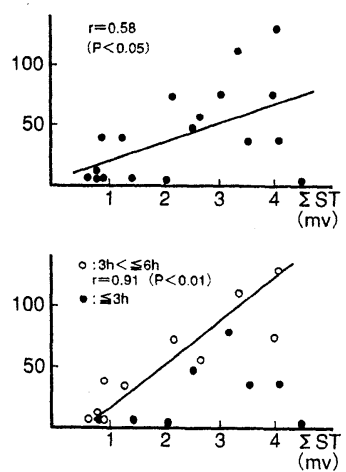

映していることが示され， $\Sigma \mathrm{ST}<2.1 \mathrm{mV}$ のも のでは, それ以上のものに比し, 有意な梗塞 量の低下が認められた。 $\Sigma$ STは心拍数, 電解 質異常, 脚ブロックの存在などにより影響を 受け，必ずしもすべての症例に適応すること はできないが, 入院時点において, Collateral Flowの程度を予測し得る最もよい心電図 パラメーターと思われ，急性心筋梗塞再灌流 療法の適応及びその効果を予測する上で, 有 用な指標と考えられた。

図1. 〈心電図パラメーター〉 〈初回冠動脈造影時の側副血行〉

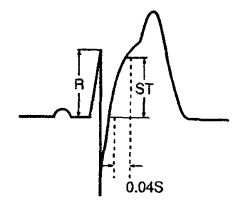

$\sum \mathrm{R}=\mathrm{R}\left(\mathrm{V}_{1}+\mathrm{V}_{2} \mathrm{~V}_{3}+\mathrm{V}_{4}+\mathrm{V}_{5}+\mathrm{V}_{6}\right)$ (mv)

$\underset{(m v)}{\Sigma S T}=S T\left(V_{1}+V_{2} V_{3}+V_{4}+V_{5}+V_{6}\right)$

Grade :

i ) (一) 一 側血行 (一)

ii） poor 一 本幹の分枝が僅かに造影

ii ) fair 一本幹は造影されるが全体 に及ばない

iv) good 一 閉塞部より末梢の本幹が 全体に造影される
図3. $\Sigma R$ and $\Sigma S T$ in relation to Collateral flow

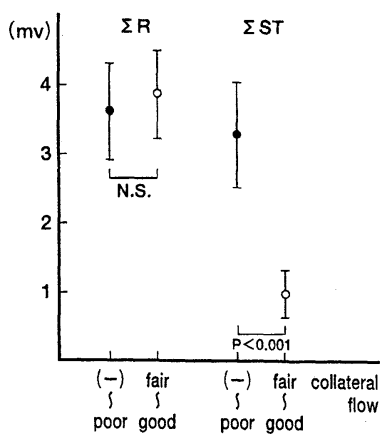

図 5.

Severity Score and collateral flow in relation to $\Sigma S T(m V)$

\begin{tabular}{|c|c|c|}
\hline & $\Sigma \mathrm{ST}<2.1$ & $\Sigma S T \geqq 2.1$ \\
\hline A. Severity Score & $\begin{array}{c}9.8 \pm 5.20^{a} \\
(\mathrm{~N}=8)\end{array}$ & $\begin{array}{c}64.5 \pm 12.1 \\
(N=10)\end{array}$ \\
\hline i ) reperfusion $\leqq 3 \mathrm{~h}$ & $\begin{array}{l}0.80 \pm 0.5^{b} \\
(N=3)\end{array}$ & $\begin{array}{c}39.3 \pm 11.7 \\
(N=5)\end{array}$ \\
\hline ii) reperfusion $3 \mathrm{~h}<\leqq 6 \mathrm{~h}$ & $\begin{array}{c}15.3 \pm 7.5^{c} \\
(N=5)\end{array}$ & $\begin{array}{c}89.6 \pm 14.2 \\
(N=5)\end{array}$ \\
\hline \multicolumn{3}{|l|}{ B. collateral flow } \\
\hline i) $\quad$ fair & 7 & 0 \\
\hline ii) $(-) \sim$ poor & 1 & 10 \\
\hline
\end{tabular}




\section{血液 疾 患}

\section{D01 r E P O を用いた自己血輸血の検討}

○山口昭彦、高津 洋

（仙北組合総合病院 内科）

他家血輸血を行らと感染症、同種抗体の出 現、アレルギーなどを生し、、輸血後も患者に 傷害を残すことがある。そこでこれからの合 併症を防ぐため今日では外科的手術に際して 自己血輸血が行われるようになった。我々は 変形性股関節症患者で戻し採血法に rEPO及 び鉄剂を併用投与することにより、自己血輸 血使用のみで人工股関節置換術を終えること が出来たので報告する。

【症例】対象は変形性股関節症の 2 症例。症 例 1 は54才、女性。両側股関節症があり、人 工股関節置換術前に自己血採血を行らため整 形外科より当科に転入院。採血前白血球 $4600 、 \mathrm{Hb} 9.7 \mathrm{~g} / \mathrm{dl}$ 、血小板 26 万。症例 2 は 50才、女性。当院整形外科で左股関節症と診 断され、術前に自己血採血を行らため $400 \mathrm{ml}$ を採血したところ Hb 13.1 gであったのが 10.9 に低下。その後血液の回復が悪く当科に 転科。入院時末梢血 白血球 $4900 、 \mathrm{Hb} 10.7$ $g$ 、血小板 35 万。

【方法】rEPO 3000 単位隔日静注し、鉄剂 としてコンドロイチン硫酸鉄コロイド $80 \mathrm{mg}$

（B１ｕtal）を連日静注しながら戻し採血 を行った。採血は最初 $400 \mathrm{m \ell}$ 、これを 1 週間 後返血し、ついで $800 m l$ 採血。さらに 1 週間 後 $800 \mathrm{ml}$ 返血、その後 $1200 \mathrm{ml}$ 採血、これを 自己血輸血に用いた。

【結果】症例 1 では投与前 $\mathrm{Hb} 9$ gであったが $\mathrm{rEPO}$ 抢よび鉄剂併用により 2 週間後 $\mathrm{Hb}$ は $11 \mathrm{~g}$ になった（図1)。その後戻し採血を繰 り返したが、貧血を来すことなく最後に 1200 $m \ell$ 採血し、これを自己血輸血に用いた。 症例 2 では採血前 $\mathrm{Hb} 13 \mathrm{~g}$ で、400 me採血後 $10 \mathrm{~g}$ になった（図 2 )。その後回復が遅く戻し 採血に rEPO及び鉄剂を併用したところ、 $\mathrm{Hb}$ $10 \mathrm{~g}$ 台のまま最後に $1200 \mathrm{ml}$ を採血することが 出来た。

【考察並びに結語】急を要しない外科的患者 では手術に際して自己血輸血行うことが多く なってきた。しかし自己血採血より患者が貧 血状態に陥るのは好ましくない。rEPOは広 く腎性貧血の改善に用いられており、慢性関 節リニウマチによる続発性貧血にも有効であ ることを我々は認めている。そこで自己血採 血のため戻し採血法に rEPO併用投与を試み たところ、貧血を来すことなく術前自己血を 採血することが出来ることが分かった。以上 我々の方法は急を要しない外科的手術に有効 であると考えられる。 
IEp 3000E 㶾日

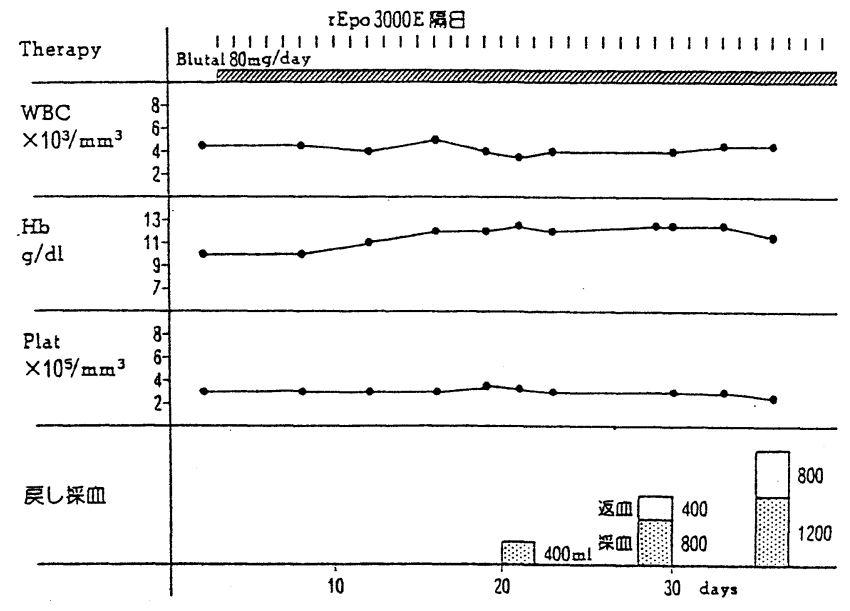

図 1 症例 1

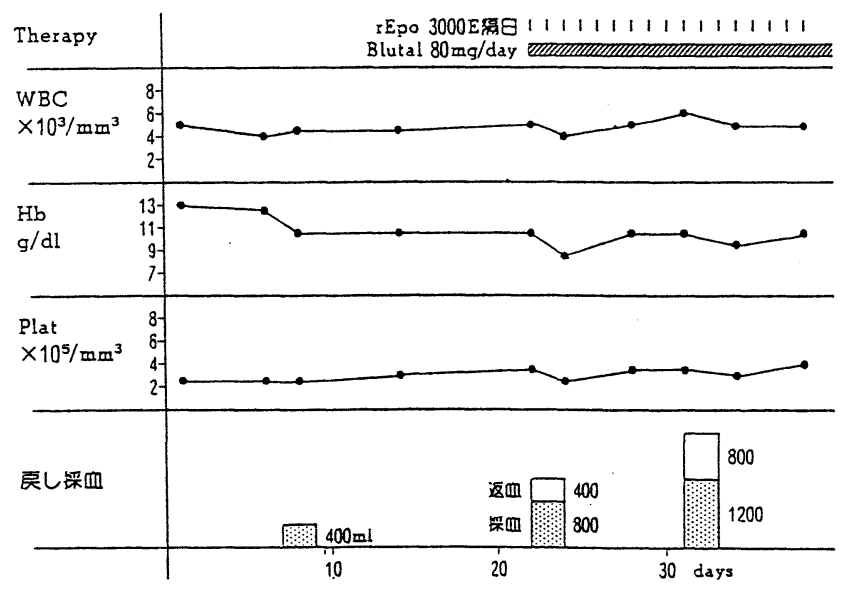

図 2 症例 2 
1D02 $\mathrm{M}$ 蛋白血症の臨床疫学的検討

O出浦喜丈、池田昌伸（長野県・佐久総合病院）

【はじめに】：高龄社会の進行に伴い、骨娟道 腫(MM)が増加傾向であるが、一方で、各種の 検診や他疾患で加療中、偶然にMGUSなどのM蛋 白血症が発見される機会も多くなっている。 骨䯣腫の発生頻度、病態や経過、早期診断の 可能性などを検討するために、最近6年間に診 断したM蛋白血症70例について検討した。

【対象と成績】: 今回検討した対象症例は、 1986年 -1991 年の6年間に当院内科（血液）で 診断したMGUS(BMG)30例、MM35例など70例で、 Ig夕イプなど合わせて表1に示したがIgGタイ プが $67 \%$ 占めた。男女比は $41: 29 て ゙ 、$ 年齢分 布は図1に示したが、60才代から70才代にもっ とも多い。MMの平均年令 66.7 才、MGUSが 60.3 寸とややMMの方が高齢であった。鎖のタイプ 別では、MGUSに比べてMMにK鎖が多い傾向があ ったが、統計的に有意差はなかった（表2）。 対象70例の診断の契機は、有症状で外来受診 した例が28例(40\%)で、残りは人間ドックなど の検診や他疾患で受診中偶然発見された例で あった（表3）。有症状群のほとんどがMMで、 これらのMMは病期では3期が多いのに対して、 検診/偶然群のMMはすべて1-2期の症例であっ た（表4）。検診などでM蛋白血症の存在をス クリーニングするためにはTP , A/G比などとと もに、ZTTが有用かつ一般的な検查値と考えら れる。表5に示したように、ZTT高値例が55.7 \%を占めたが、MMを中心にZTT低值例も22.9\%認 められた。診断時の賓血はMM例の85.7\%に見ら れたが、MGUSでは $10 \%$ みであった（表 6$) 。$ MMとMGUS（BMG）との鑑別が問題となる症例も
時にみられるが、図2にMMとMGUSにおけるM蛋 白に対応する診断時のIg值を示した。IgG夕イ プのMGUSで3例が IgG 3g/dlの值をしめしたが これらの例はMMの初期である可能性が高い。 一方、今回診断した 35 例のMM中 2 例では、MGU ふとしての臨床経過が先行していた。表7に、 M蛋白以外のIg値の減少例を示したが、MGUS でも約20\%は、2系以上のIg減少が観察され、 必ずしもMMとの鑑別には役立たない。

【考察】：高齢化社会の進行に伴いMMが増加 しているが、本来慢性に経過するMM例が案外 病期が進行して有症状になってから診断され る例が多い。検診/偶然群では病期の早い例 が多いので、今後さらに検診精度を上げる必 要がある。MMの早期例を含むと考元られるMG USへのアプローチ法もまだ十分とはいえない。 MMの” 前癌病変”とも考元られるMGUSの検討 は、MMの自然経過や病態を研究する上でも重 要と思われる。今後さらに、今回検討した数 倍あると推定される当院のMGUSを加えて検討 をつづける予定である。また、TP、A/g比、ZTT、 蛋白分画などによる血清蛋白異常 $\rightarrow M$ 蛋白血症 のスクリーニング方法についても検討を加え る予定である。 
表 1 対象70症例（1986～1991年）

\begin{tabular}{|c|c|c|c|c|c|c|}
\hline $\mathrm{S}_{\text {症例 }}^{M \text { M }}$ & IgG & IgA & IgM & $\mathrm{BJ}$ & 不明 & 合計 \\
\hline MGUS(BMG) & 24 & 3 & 2 & 0 & 1 & 30 \\
\hline MM & 23 & 7 & 0 & 5 & 0 & 35 \\
\hline $\mathrm{Mgl}$ & 0 & 0 & 3 & 0 & 0 & 3 \\
\hline リパ 系腫瘍 & 0 & 0 & 2 & 0 & 0 & 2 \\
\hline
\end{tabular}

MGUS : Monoclonal gammopathy of undetermined significance

MM : Multiple myeloma

Mgl : Macroglobulinemia

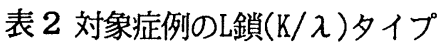

\begin{tabular}{|l|r|r|l|r|}
\hline & $\mathrm{k}$ & $\boldsymbol{\lambda}$ & 不明 & 合計 \\
\hline MGUS & 12 & 14 & 4 & 30 \\
MM & 21 & 14 & 0 & 35 \\
Mgl & 1 & 1 & 1 & 3 \\
リソパ 糸腫場 & 0 & 1 & 1 & 2 \\
\hline
\end{tabular}

表 3 対象70症例の診断ルート

\begin{tabular}{|l|l|}
\hline 検診群 & $20(28.6 \%)$ \\
偶然群 & $22(31.4 \%)$ \\
有症状群 & $28(40.0 \%)$ \\
\hline
\end{tabular}

表 4 骨骨迶腫(MM)の診断ルートと病期

\begin{tabular}{|c|c|c|c|c|}
\hline 病期 & I & II & III & 合計 \\
\hline 検診～偶乡 & 6 & 5 & 0 & 11 \\
\hline 有症状群 & 0 & 4 & 20 & 24 \\
\hline
\end{tabular}

表 5 対象症例の診断時ZTT值

\begin{tabular}{|c|c|c|c|c|c|c|}
\hline $\begin{array}{c}\text { ZTT } \\
\text { 症例 }\end{array}$ & $0 \sim 2$ & $\begin{array}{l}\text { (正常) } \\
2 \sim 13\end{array}$ & $\begin{array}{r}(\sim 2 x) \\
13 \sim 26\end{array}$ & $\begin{array}{l}(2 x \sim \\
26 \sim\end{array}$ & 不明 & 合計 \\
\hline MGUS & 1 & 11 & 11 & 5 & 2 & 30 \\
\hline MM & 13 & 1 & 5 & 16 & 0 & 35 \\
\hline & 2 & 0 & 1 & 0 & 0 & 3 \\
\hline リパ 糸腫瘍 & 0 & 1 & 0 & 1 & 0 & 2 \\
\hline 合計 & $\begin{array}{c}16 \\
(22.9 \%\end{array}$ & $\begin{array}{c}13 \\
(18.6 \%\end{array}$ & $\begin{array}{c}17 \\
(24.3 \%)\end{array}$ & $\begin{array}{c}22 \\
(31.4 \%)\end{array}$ & $\begin{array}{c}2 \\
(2.9 \%)\end{array}$ & 70 \\
\hline
\end{tabular}

図 1 MM, MGLとMGUSの年令分布

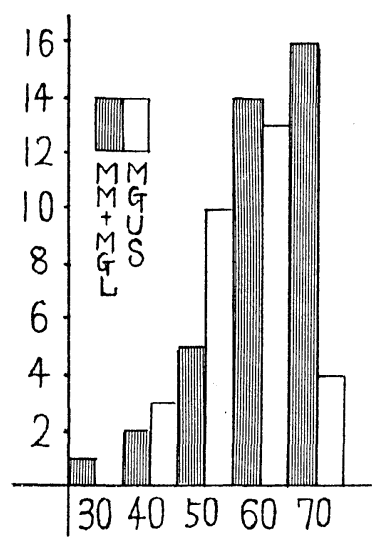

表 6 対象症例の診断時の貧血

\begin{tabular}{|l|l|}
\hline MGUS & $3 / 30(10 \%)$ \\
MM & $30 / 35(85.7 \%)$ \\
Mgl & $3 / 3(100 \%)$ \\
ツM 糸腫傷 & $1 / 2(50 \%)$ \\
\hline
\end{tabular}

表 7 M 蛋白以外 Ig 低下例

\begin{tabular}{|l|c|c|}
\hline & 1タイプ以上 & 2夕イプ以上 \\
\hline MGUS & $27.6 \%$ & $20.7 \%$ \\
MM & $85.7 \%$ & $65.7 \%$ \\
\hline
\end{tabular}

図 2 MM(MGL) とMGUSの I g值

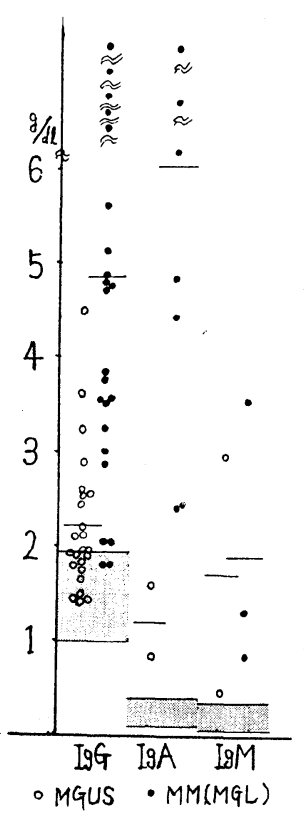




\section{秋田県農村地域における ATL (関連疾患)を含む疫学的研究}

*西村茂樹、朝倉健一、佐藤涼子、山口昭彦、

高津洋、高橋徹、月沢恵子、佐藤孝、渡部和弘、

工藤和治、佐伯重昭、伊藤進、斉藤正信、唐牛襄、

*由利組合総合病院、秋田県厚生連ATL研究班員

はじめに

成人 T細胞门佔病・リンパ腫 (adult T cell leukemia/Lymphoma,ATL）は日本で発見され 淤载された疗患である。その病因にウィルス が関!jしていることがわかり注目を集めてい

いては, EBウイルスとBurkittリンパ腫およ び與呐頭癌，ヘルペスと子宮䅡癌，B型肝炎 ウィルスと肝沾などが論じられてきた。ATL の於因ウィルスHTLV-I (human T lymphotropic virus 1）はこれらDNAウィルスと違ってRNA 朠場ウィルスに属する。RNA腫瘍ウィルスは 電子顕微鏡的特徵からC型RNAウィルス, 逆 転等醋素（reverse transcriptase）をもつこと からレトロウィルス（retrovirus）, さらに腫 掦の原因となることからオンコルナ (oncoruna virus）などと呼ばれている。

[研究目的]

従来HTLV-I感染は日本南西部に最も濃厚で ある。HTLV-I抗体陽性率とATL患者発生の地 理的分布は一致し, 九州地域 $8.0 \%$ 近畿地域 $1.2 \%$ 東北地域 $1.1 \%$ となっている。秋田県に 抢けるATLの免疫学的研究を厚生連の病院で 其闹研究を行なった。

1】過去 5 〜 10年間に打ける各病院における ATL患者（及び関連疾患）について

(平成 2 年)

2】各病院に打けるHTLV-I感染ハイリスクグ ループにおけるHTLV-I抗体調査 (平成 3 年)

3】-・般住民検彰, 人間ドックにおけるHTLV-I 抗体調査（平成 4 年）を 3 年間にわたって行
なった。

\section{[結果〕}

1. 病型は熊本大学方式とした。

1】急性型 1 例、慢性 5 例、くすぶり型3例、 リンパ腫型 5 例、HAM症例 4 例、その他キ ヤリアー8例認められた。感染経路としては (1) 母 $\rightarrow 1$ 児5例 (2)男 $\rightarrow$ 女（夫婦間） 3 例 (3)輸血が原因とされる症例は 6 例であった。

（表1）2】平成 3 年度は，各施設における 入院患者について慢性腎不全（透析）患者, 悪性腫瘍患者, 膠原病自己免疫疾患, 血液疾 患（悪性リンパ腫, 再生不良性貧血, 白血 病, その他) 免疫不全及び類似疾患患者につ いてHTLV-I抗体を検討した（表 2 ）。全体512 名のうち 11 例陽性 $2.14 \%$ 内訳：慢性腎不全 2/125（1.6\%）悪性腫瘍（昌癌） $1 / 76 （ 1.3$ $\%$ ）血液疾患 $7 / 233(3.0 \%)$ 膠原病 $0 / 63(0$ \%）その他 $1 / 156 \%$ となった。秋田県 赤十字血液センター（平成 2 年）71,659人の 献血者のうち497名HTLV-I陽性（0.69\%）に 対して，上記ハイリスクグループは 3.1 倍の 陽性率を示した。3】一般住民㭘診・ドッグ 受診患者におけるHTLV-I抗体調査（表3）： セロディア・HTLV-I試験薬（富士レビオ $\mathrm{K} . \mathrm{K})$ を用いて, 同一施設において, 検体を 集積して行なった。2,868名のうち陽性者は 23 名 $(0.8 \%)$ であった。地域別では鹿角 $1 /$ 360 例 $(0.2 \%)$ 山本 $1 / 161$ 例 $(0.6 \%)$ 秋田 $0 / 140$ 例 $(0 \%)$ 仙北 $(0.5 \%)$ 由利 $17 / 1335$ 例 $(1.3$ $\%)$ 平鹿 $2 / 337$ 例 $(0.6 \%)$ 雄勝 $0 / 110(0 \%)$ で, 特に由利地域に頻度が高く検出された。 
特に調查した $\mathrm{N}$ 町は一䇥の地域でありこの

地域での活染率の高いことが判明した。年代

別では30才以下 $0.4 \%$ 。 31 才から60才まで 0.6

\%. 61 才以上 $1.2 \%$ と年令が上昇するにつれ

て頻度が上昇した。男女比はほほ1：1で

あった。これら陽性例に対しては，IF法，

EIA法にて精査中である。

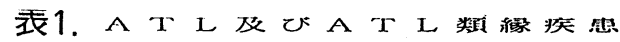
由利組合秷合病院

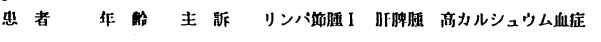

\begin{tabular}{|c|c|c|c|c|c|c|c|c|c|}
\hline 急 & 性 & 型 & S. 1 & 73 & 男堆 & 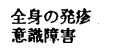 & $(-)$ & $(-)$ & $14.8 \mathrm{ng} / \mathrm{dl}$ \\
\hline \multirow[t]{3}{*}{ 设 } & \multirow[t]{3}{*}{ 性 } & \multirow[t]{3}{*}{ 型 } & N. J & 58 & 男性 & 手闺的行 & - & - & 9.4 \\
\hline & & & H. $\mathrm{T}$ & 44 & 男排 & 検 翮 & - & - & 9.8 \\
\hline & & & S. $\mathrm{K}$ & 52 & 男性 & 陈闺的符 & - & - & 9.0 \\
\hline \multirow[t]{2}{*}{$<$} & \multirow[t]{2}{*}{ tぶり } & & 1. $\Lambda$ & 36 & 罗性 & 假 然 & - & - & 9.0 \\
\hline & & & K. $\mathrm{T}$ & 43 & 罗性 & 件然 & - & - & 9.6 \\
\hline \multirow[t]{4}{*}{ リン } & \multirow[t]{4}{*}{ ンバ徆 } & & S. $M$ & 55 & 性 & 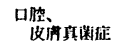 & $(+)$ & $(-)$ & $9.2 \rightarrow 11.8$ \\
\hline & & & O. $\mathrm{K}$ & 62 & 罗性 & 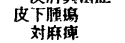 & $(+)$ & $(-)$ & 11.6 \\
\hline & & & o. $\mathrm{Ka}$ & 56 & 女性 & 㑫急感 & $(+)$ & $(-)$ & 10.8 \\
\hline & & & 1. $\mathrm{E}$ & 50 & 男性 & 咽顽病 & $(+)$ & $(-)$ & 9.2 \\
\hline そ & の & 他 & W. $\mathrm{K}$ & 65 & 姝 & $\begin{array}{l}\text { 歩行障害 } \\
\text { ※(OCC) }\end{array}$ & $(-)$ & $(-)$ & 10.8 \\
\hline \multirow[t]{4}{*}{ * } & \multirow[t]{4}{*}{$+y$} & $T-$ & 1. 0 & & 女陫 & ATLA抗体 & & \multicolumn{2}{|c|}{ フロ少ィラス DNA (陽性) } \\
\hline & & & S. $K$ & 57 & 女性 & ATLA沆体 & $250 \times$ & & " \\
\hline & & & S. $\mathrm{T}$ & 54 & 男性 & ATLAI亢体 & $256 \times$ & & " \\
\hline & & $\Delta \mathrm{m}$ & $\begin{array}{l}\text { H. S } \\
\text { S. S } \\
\text { 拉院应(例) }\end{array}$ & 60 & $\begin{array}{l}\text { 男垃 } \\
\text { 女性 }\end{array}$ & $\begin{array}{l}\text { ATLAL亡tik } \\
\text { HTLV-1 }\end{array}$ & $\begin{array}{l}256 x \\
256\end{array}$ & 以上 & \\
\hline
\end{tabular}

(什北和合紷合护院应例)

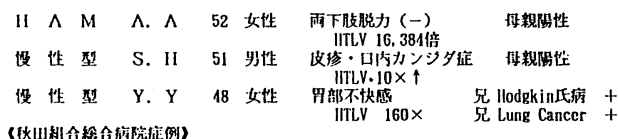

II $\wedge \mathrm{M} \quad \mathrm{N} . \mathrm{Y} \quad 57$ 女性 IITLV-1 $320 \times$ 以上少行障害、知觉障害

H $\wedge \mathrm{M}$ S. F 46 婎

(平吧矮合疗院柾例)

吣性リンハ腄型 H. T 54 女性

くすぶり型 S. K 74 女性

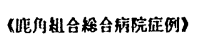

$\begin{array}{crrr}\text { キ+リアー } & \text { N. I } & 43 & \text { g)性 } \\ " & \text { N. J } & 30 \text { 女性 } \\ " & \text { N. K } & 0 \text { 女栍 }\end{array}$

表2.

HTLV一I抗体調結果

(平成 3 年月月、12月)

[まとめ]

$\mathrm{HCV}$ 抗体652各/71,659各 $(0.91 \%)$ に比し HTLV-I抗体陽性者は $0.8 \%$ で沃して無視出来な い数值である。少なくとも妅娠している人の HTLV-I抗体は必須で，母子感染を令防し，種 々の疾患の病因と考えられるHTLV-I感染を予 防することは, 輸血時の検査とともに大切で あることを強調したい。

$320 \times$ 以上 步行陪害、知賞障害

予後实他 VBPA

VEPA MLA A 4 月 +

橙度

88年10月

88年 1 月

88位 7月

88作 7月

88仵 2 月

VGPA-VP16

88作 5 月

CDUP. VBPA
89作 1 月

90作 12 月

87年 6 月

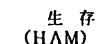

生 存

答 血

生存

生 右

桷县

5年

生估

生 标

生存。

\begin{tabular}{|c|c|c|c|c|}
\hline & 30才以下 & $31 才-60 才$ & 61才以上 & 㖕 \\
\hline 鹿角 & 30 & 130 & $\begin{array}{c}200 \text { (1) } \\
\text { 男 (1) }\end{array}$ & $\begin{array}{c}360 \text { (1) } \\
\text { 男 (1) }\end{array}$ \\
\hline 山本 & 0 & $\begin{array}{c}100(1) \\
\text { 女 (1) }\end{array}$ & 61 & $\begin{array}{c}161 \text { (1) } \\
\text { 女 (1) }\end{array}$ \\
\hline 秋田 & 41 & 99 & 0 & 140 \\
\hline 仙北 & $\begin{array}{l}50 \text { (1) } \\
\text { 男 (1) }\end{array}$ & $\begin{array}{c}255(1) \\
\text { 男 (1) }\end{array}$ & 120 & $\begin{array}{c}425 \text { (2) } \\
\text { 男 (2) }\end{array}$ \\
\hline 由利 & 82 & $\begin{array}{c}871 \text { (8) } \\
\text { 男(1) 女(1) }\end{array}$ & $\begin{array}{c}382 \text { (9) } \\
\text { 男(5) 女(4) }\end{array}$ & $\begin{array}{c}1,335(17) \\
\text { 男(7) 女(10) }\end{array}$ \\
\hline 平鹿 & 1 & 101 & $\begin{array}{c}235 \text { (2) } \\
\text { 男(1) 女(1) }\end{array}$ & $\begin{array}{c}337 \text { (2) } \\
\text { 男(1) 女(1) }\end{array}$ \\
\hline 雄勝 & 13 & 84 & 13 & 110 \\
\hline & $\begin{array}{c}217 \\
\text { 男 (1) }\end{array}$ & $\begin{array}{l}1,640 \\
\text { 男 (3) } \\
\text { 女 (7) }\end{array}$ & $\begin{array}{l}1,011 \\
\text { 男 (7) } \\
\text { 女 (5) }\end{array}$ & $\begin{array}{c}2,862 \\
\text { 男 (11) } \\
\text { 女 (12) }\end{array}$ \\
\hline
\end{tabular}

84年 5 月

82作 6月

WHC 10100

表3. 各地域におけるHTLV-I抗体調査

875F 9月 ・年絽Ope

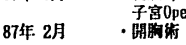

90作11月 DIC庭候群

90年10月

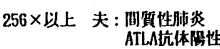

ATLA杭体陽性

90年10月

89年 5月

90年 1月

\begin{tabular}{|c|c|c|c|c|c|c|c|c|c|}
\hline & 鹿 角 & 山本 & 減 果 & 秋 田 & 由 利 & 仙北 & 平鹿 & 散 & $H$ \\
\hline 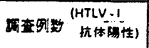 & $71(1)$ & $44(1)$ & 27 & $46(1)$ & $94(2)$ & 75 & $141(4)$ & $14(2)$ & $512(11)$ \\
\hline 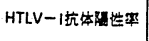 & $(1.40 x)$ & $(2.27 x)$ & & $(2.17 x)$ & $(2.12 x)$ & & $(2.83 \mathrm{x})$ & (14. 28x) & $(2.14 x)$ \\
\hline 㑩时不全 & 15 & 3 & & 20 & $41(1)$ & 36 & & $10(1)$ & $125(2)$ \\
\hline 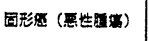 & $4.7(1)$ & 5 & 12 & 1 & 10 & & & 1 & $76(1)$ \\
\hline 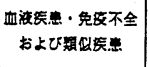 & 6 & $23(1)$ & 9 & $18(1)$ & $31(1)$ & 16 & $129(3)$ & 1 (1) & $233(7)$ \\
\hline 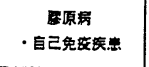 & 2 & 9 & 6 & 3 & 7 & 23 & 11 & 2 & 63 \\
\hline その他 & 1 & 4 & & 4 & 5 & & $1(1)$ & & $15(1)$ \\
\hline
\end{tabular}


1D04 $G-C S F$ 投与にて血液所見の改善をみて E S T を施行し得た M D S 1 例

広島県厚生連府中総合病院内科

O 品川晃二, 佐藤俊雄, 林 天明, 藤田道雄, 中川三郎, 河田典子, 佐藤玲美

当初診断困難であった骨䯣異形成症候群 (M DS）の経過中汎血球減少の時期に胆囊総胆管 結石による胆道炎を合併し，G-CSFを使用した 所白血球の増加を見, 内視鏡的乳頭括約筋切 開術(EST) を重篤な感染症を併発することな
エリスロポエチンが高值であった。骨䯣像は 有核細胞数 18.6 万, 赤芽球系 $1.2 \%$, 顆粒球系 $88.8 \%$ (内骨䯣芽球 $0.0 \%$, 前骨䯣球 $10.4 \%$, 骨䯣 球 $18.8 \%$, 後骨䯣球 $7.2 \%$ ) リンパ球は $6.8 \%$, で 赤芽球系が著減しており, 好中球系の増加之 その幼若細胞の軽度増加があったが 3 系統に わたって血球の形態異常はなかった.Sider $0 b$ lastgramでは環状鉄芽球はなく，吕型優位で あった．以上より一応赤芽球疼と診断し，岡 山大学第二内科に精査の為入院した.

しかし 2 ヶ後より, 白血球特に好中球が 減少し始めた。既往症, 職業歴等から二次性 の赤芽球疼又は再生不良性貧血, 又は前白血 病状態の可能性も考えられた。

平成 2年 1月より貧血に対しプリモボラン $30 \mathrm{mg} / \mathrm{D}$ の内服を開始し, 5 月に退院後は当院と 岡山大学で外来通院した。血液検查は毎週行 ったが貿血は改善されず, 赤血球数 200万を およその目安として適宜濃厚赤血球輸血を行 った。全経過は困示.

プリモボランの効果は殆ど認めず, 5 ケで 中止した. in vitroのcolony assay (CFU-E assay)で(1)患者骨髓液にプレドニゾロンを添 加してコロニー数の増加を認めたこと(2)患者 血清を正常人CFU-E assay 系に添加して抑制 がみられたこと等から免疫に関与した貧血の 可能性も考えられたため, プレドニゾロン20

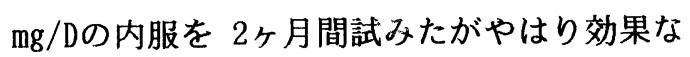
く，更には血小板も減少してきたため 7月に 中止した.

代わってチオデロン $30 \mathrm{mg} / \mathrm{D}$ の内服を開始し 


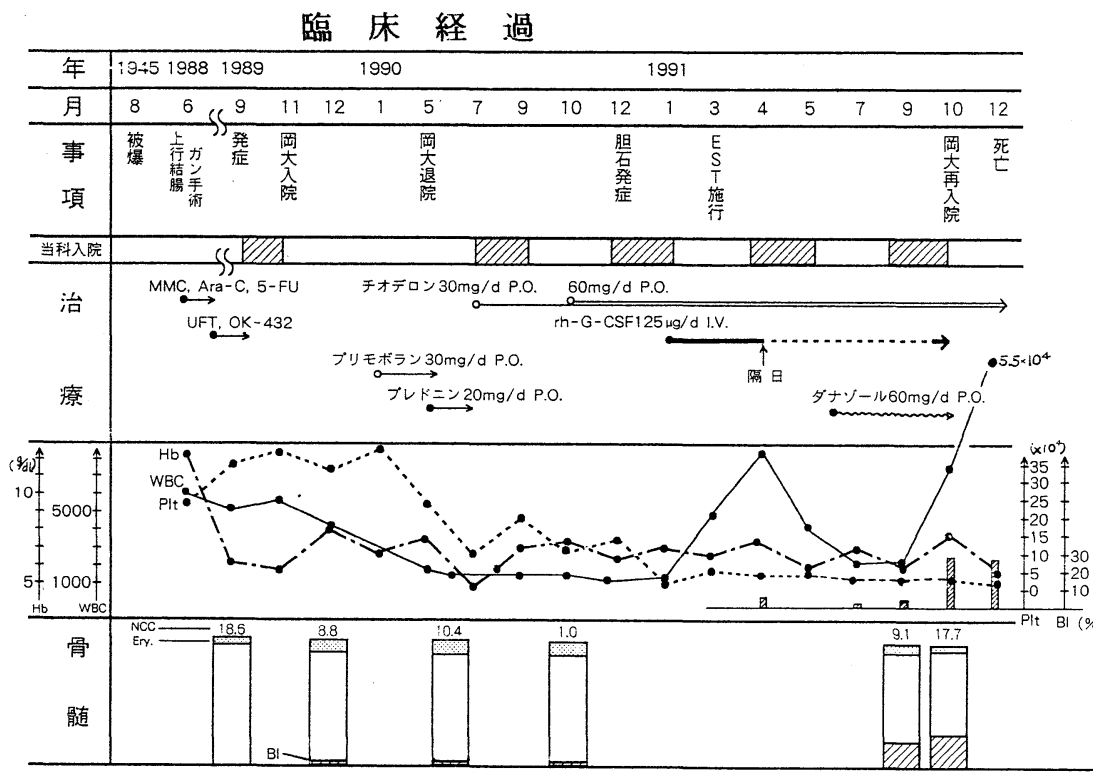

った．嵌頓していた総 胆管結石は小さく $2 \mathrm{~mm}$ 大であった．出血はか なりつづいたが白血球 数が正常化していたた め懸念された術後感染 症の合併もなく術前あ った肝機能障害や炎症 反応も改善した. 平成 3年 4月より末梢血に 骨䯣芽球が散見される ようになり,G-CSFの芽 球增殖刺激作用も疑水

たところ，輸血の間隔が長くなって来たこと より䞄血の改善に効果があったと考え，10月 より60mg/Dに增量した. しかし12月になって 全身僚急, 食欲不振を訴え, 当科に再入院し た。入院一週間後に発熱を伴う右季胁部疝痛 発作を来し, 黄㾝及び胆道系䤃素の上昇と炎 症反応を認めた。しかし沉血球減少は持続し た. 腹部エコーでは胆囊は軽度腫大し内部に acoustic shadow を伴う結石エコーあり, 総 胆管は結石は不明だが $14 \mathrm{~mm}$ と拡張していた 、腹部CTでも胆囊壁は軽度肥厚し, 胆囊内に positive stoneを認めた. 総胆管の拡張も認 められた. 以上より胆石の総胆管への嵌頓に よる胆道感染症の合併と診断した. 汎血球減 少があるため手術は出来ず，保存的に治療し たが血液検査, 症状とも改善が見られなかっ たため, 白血球の増加を目的としてG-CSF 12 $5 u g / D$ の静注を平成 3 年 1 月から開始した所 ，発熱などの炎症症状が渐次軽快し，白血球 数, 特に好中球数が正常值汽增加し, 血小板 もやや増加, 出血, 凝固時間も正常之なった ・そこで総胆管結石症に対して最も侵襲の少 ない治療法として ESTを岡山赤十字病院で行
れたため減量した。

その後Hbが 5〜 6g と改善しないため, 7 月よ りダナゾール600mg/D の追加投与を行った所 ，貣血の進行は抑えられたようであったが， 芽球の比率は不変で $4 \%$ 前後続いた. 9 月の 骨髄像では骨髄芽球12.4\%, 前骨髄球36.6\%,で MDS のRAEBに相当する所見であった.

9 月になり, 発熱多臟器感染を併発し, 10 月には白血球数が 8,000位に増加し, 骨䯣芽 球が急増して $30 \%$ 前後となり, 急性白血病化 し, 白血球数も55,000まで急増し, 重症肺炎 を含む多臟器感染症を併発して死亡した。

本症例は初診時, 赤芽球疼又は再生不良性 貞血の非定型例と考えられたが 1 年 2 月月後 芽球が末梢血に散見されるようになり，骨䯣 像で MDSのRAEBに相当する所見が得られ最後 は白血病化したが, 経過中胆石による閉塞性 胆道感染症を併発した際, G-CSFを投与するこ とにより白血球を増加させて炎症を抑え，更 に総胆管結石の根治的治療である ESTを行い 得て, 術後の感染症の合併を来すことなく術 後数ヶ月を順調に過ごせたことはG-CSF が有 効であったと考えられた。 